ROCZNIKI HISTORYCZNE

Rocznik LXXXII - 2016

\title{
ROZPRAWA
}

TOMÁŠ VELIČKA (Univerzita Karlova, Praha)

\section{Zeměpanské konfirmační listiny pro slezská města do počátku 15. století $^{1}$}

Zarys treści: Przedmiotem artykułu są dokumenty konfirmacyjne władców do początku XV w. przeznaczone dla miast śląskich. Są one analizowane pod względem okoliczności powstawania, zawartości, typologii, formularza, a także porównywane $\mathrm{z}$ analogicznymi dokumentami z innych ziem Korony Czeskiej.

Content outline: The subject of the paper are confirmatory documents of issued by rulers for Silesian towns until early $15^{\text {th }}$ century. They are analysed on the basis of the circumstances of their creation, their content, typology, formulary, as well as comparisons with similar documents from other regions of the Bohemian Crown.

Słowa kluczowe: dokumenty, dyplomatyka, średniowiecze, Śląsk, miasta, król czeski, książęta, Korona Czeska

Keywords: documents, diplomatics, Middle Ages, Silesia, towns, king of Bohemia, dukes, Bohemian Crown

\section{I. ÚVOD}

\section{Představení tématu}

V posledních několika desetiletích se v diplomatice objevily některé nové trendy, které jsou spojeny s výzkumem jednotlivých listinných formulí2, nebo vůbec s novým interdisciplinárním př́istupem k úředním produktům. Některé tendence se pojí s novým nazíráním na vnější znaky listin, které chápou listinu jako systém jazykových, grafických a materiálních kódů v komunikačním procesu³. Obor se neobohacuje jen

${ }^{1}$ Tato studie je zkrácenou verzí př́islušných pasáží mé disertační práce: Zeměpanské konfirmační listiny pro česká a slezská města do roku 1420 (V rámci diplomatické produkce panovnických kanceláŕí), obhájenou na katedře Pomocných věd historických a archivního studia Filozofické fakulty Univerzity Karlovy v Praze v září roku 2014 (př́stupná na webu: $<$ https://is.cuni.cz/webapps/zzp/detail/101630>).

${ }^{2}$ Arengy či intitulace. H. F i c h te n a u, Arenga. Spätantike und Mittelalter im Spiegel von Urkundenformeln, Graz 1957; H. W o 1 f r a m, Intitulatio, t. I-III., Graz-Wien, 1967-1988.

${ }^{3}$ P. W o r m, Ein neues Bild von der Urkunde: Peter Rück und seine Schüler, Archiv für Diplomatik 52, 2006, s. 335-352. 
metodicky, ale i materiálově. Diplomatika se již dlouho neomezuje jen na výzkum listinného materiálu, ale přihlíží i k úředním knihám rozličného charakteru ${ }^{4}$, jakkoliv kořeny těchto trendů lze sledovat již v závěru 19. století. Jejich množství a šíře výrazněji narůstá $\mathrm{v}$ posledních dvou staletích středověku. Tento nárůst se dotýká i listinného, mandátového a listového materiálu, který zvláště v 15. století (zůstaneme-li v prostředí střední Evropy) již nabývá těžko přehlédnutelných rozměrů (alespoň v prrípadě velkých kanceláŕí). Někdy se proto hovoří o diplomatických pramenech pozdního středověku jako o „problému masy“s.

Pro diplomatická studia pozdního středověku lze již jen stěží pokrývat plošně celý dochovaný materiál. Zatímco pro 1. polovinu 14. století je to ve středoevropském prostředí v zásadě ještě možné, pro druhou polovinu století již materiál narůstá do obrovské šíře, který není jedincem zvládnutelný ${ }^{6}$. Jedním z východisek, které se tu nabízí, je realizace speciálně zaměřených studií na vybrané části listinného materiálu jednoho nebo více př́ijemců - at' už se bude jednat o části listinného formuláře, druh písemností podle různých znaků či podle jazyka atd.

Předkládaná práce se řadí do tohoto proudu bádání. Jejím předmětem bude specifický druh panovnických listin, v nichž jejich vydavatelé potvrzovali rozličné právní akty. Hovoříme o potvrzovacích neboli konfirmačních listinách. Tento listinný druh nás bude zajímat $\mathrm{v}$ průřezu zeměpanských vydavatelů ve Slezsku do roku 1419, kdy umírá český král Václav IV., př́ímý vladař nad některými slezskými knížectvími a vrchní lenní pán nad ostatními vévodstvími v regionu. Př́ijemecky se omezujeme jen na zeměpanská města. Čtenáři tu tedy předkládám studii, která si nedává za cíl postihnout ani kompletní konfirmační produkci jednoho teritoria během celého středověku, ani nepostihuje všechny př́ijemecké skupiny. Kdybychom ji chtěli rozšíriit do takových parametrů, narazili bychom na výše zmíněný problém masy - zvládnutí celé materie $\mathrm{v}$ dohledné době. Zvolený model je tak jakýmsi kompromisem mezi dosažitelností výsledků na jedné straně a jejich relevancí na straně druhé.

\section{Metodika, literatura, prameny}

Jakou metodickou oporu může mít autor, který se chce věnovat této problematice, v dosavadních zpracováních? Předem je třeba říci, že konfirmačním listinám dosud v literatuře nebyla věnována př́liš velká pozornost. Ve své studii jsem se metodicky opřel př́devším o dvě práce, které samy o sobě představují jedny z mála plošných zpracování této materie. Jedná se jednak o německou studii Dirka Hewiga, který se zabýval zeměpanskými středověkými konfirmacemi pro říšská města, stejně jako

${ }^{4}$ H. P a t z e, Neue Typen des Geschäftsschriftgutes im 14. Jahrhundert, v: Der deutsche Territorialstaat im 14. Jahrhundert, t. I., Stuttgart 1970, s. 9-64.

${ }^{5}$ I. H l a vá č e k, Das Problem der Masse. Das Spätmittelalter, Archiv für Diplomatik 52, 2006, s. 371-394.

${ }^{6}$ Viz recenze J. S p ě vá č k a na knihu: I. Hlaváček, Urkunden- und Kanzleiwesen des böhmischen und römischen Königs Wenzel (IV.), v: Československý časopis historický 18, 1970, s. 466-471 a následná diskuze I. H 1 a v á č e k, K otázce diplomatické práce v pozdním středověku, tamtéž 19, 1971, s. 574-582; J. S p ě vá č e k, K metodice diplomatické analýzy pozdně středověkých listin, tamtéž 19, 1971, s. 734-742. 
potvrzovacími listinami zemských práv v raném novověku ${ }^{7}$. Druhou základní prací je kniha Lenky Martínkové, která svou pozornost věnovala zeměpanským konfirmacím pro moravské př́ijemce z doby lucemburské ${ }^{8}$. Pro starší období jmenujme v sedmdesátých letech 20. století vzniknuvší pojednání Hermanna Krauseho, který problematiku potvrzovacích listin ukázal na raných Barbarossových listinách let 1153-11589 . Pro mladší období (14. a 15. století) vznikla poměrně nedávno práce Renaty Spreitzer ke konfirmačním a lenním listinám krále Zikmunda pro rakouského vévodu Albrechta $\mathrm{V}^{10}$. Autorka tu zkoumá listiny vydané Zikmundem Lucemburským roku 1421 Albrechtovi V. Habsburskému. Na samotný sklonek středověku se dostáváme ve studii Josefa Pausera ${ }^{11}$. Nastiňuje v ní složitost konfirmačního procesu měst Krems a Stein v Dolních Rakousích na počátku vlády Ferdinanda I. Vedle těchto prací pak můžeme s prospěchem vzít do rukou ještě některé další. S konfirmacemi se také pojí starší monografie They Vienken o délce platnosti středověkých právních dokumentů, jejíž časový záběr končí až ve 14. století, takže zahrnuje též dobu vlády českých Lucemburků v říši ${ }^{12}$. K teoretické právní klasifikaci konfirmačních listin raného novověku existuje rovněž podnětná studie Heinze Mohnhaupta ${ }^{13}$. Článek, který konfirmace nemá přímo v názvu, ale podstatně se jich dotýká, je pojednání Petera Bruna ${ }^{14}$. Odkrývá v ní tak trochu jiný rozměr královských konfirmací - a to na př́kladu Zikmundových listin pro aargauská města na pozadí jeho soupeření s Friedrichem IV. Habsburským. Vedle citovaných prací byly v zahraničí sepsány i některé jiné relevantní studie, jejichž význam již není tak klíčový jako u výše uvedených bádání ${ }^{15}$.

${ }^{7}$ D. H e w i g, Kaiserliche Bestätigungen von Stadt- und Landrechten, Augsburg 1969.

${ }^{8}$ L. M a r tín k o vá, Zeměpanské konfirmační a konsensní listiny z lucemburské doby pro moravské prríjemce, Brno 2003.

9 H. Kra u s e, Die Rolle der Bestätigung in der Hohenstaufenzeit. Dargelegt an den frühen Barbarossa-Urkunden, v: Rechtsgeschichte und Rechtsdogmatik. Festschrift Hermann Eichler zum 70. Geburtstag, Wien 1977, s. 387-409. Ten mimo jiné jako první, pokud je mi známo, upozornil na nepřesnost záznamů v regestových edicích, které jsou často, pokud jde o konfirmace, zavádějící.

${ }_{10}$ R. S p re it z e r, Die Belehnungs- und Bestätigungsurkunden König Sigismunds von 1421 für Herzog Albrecht V. von Österreich. Eine historische und textkritische Einordnung (1282-1729), Mitteilungen des Instituts für Österreichische Geschichtsforschung 114, 2006, s. 289-328.

11 J. P a u s e r, Privilegienkonfirmation in der Zeit Ferdinands I. Die Bestätigung der Privilegien der Städte Krems und Stein und ihr Privilegienverzeichnis von 1528, Mitteilungen des Instituts für Österreichische Geschichtsforschung 117, 2009, s. 284-311.

12 Th. Vi e n k e n, Die Geltungsdauer rechtlicher Dokumente im früh- und hochmittelalterlichen Reich, Marburg 1941 (Marburger Studien zur älteren Geschichte, II 6).

${ }^{13} \mathrm{H}$. M o h n h a u pt, Confirmatio privilegiorum, v: Privileg im europäischen Vergleich, Frankfurt a. M. 1999, s. 45-63; Srov. též H. K r a u s e, Dauer und Vergänglichkeit im mittelalterlichen Recht, Zeitschrift der Savigny-Stiftung für Rechtsgeschichte. Germanistische Abteilung 75, 1958, s. 206-251.

${ }_{14}$ P. B r u n, Von Sinn und Unsinn königlicher Privilegien - Der Aargau um 1415, v: Wege zur Urkunde. Wege der Urkunde. Wege der Forschung. Beiträge zur europäischen Diplomatik des Mittelalters, Wien-Köln-Weimar 2005, s. 169-179.

${ }^{15}$ G. H ö d l, Die Bestätigung und Erweiterung der österreichischen Freiheitsbriefe durch Kaiser Friedrich III., v: Fälschungen im Mittelalter, t. III., Hannover 1988, s. 225-246; B. T ö p fer, Bestätigungen des Verbots von Städtebünden von 1231 zugunsten des Bischofs von 
Pro slezské prostředí vznikla v nedávné době studie Přemysla Bara, kde se její autor zabývá hromadnými konfirmacemi Zikmunda Lucemburského na počátku jeho vlády ${ }^{16}$. Př́mo městské prostředí sledoval $\mathrm{v}$ tomto kontextu autor této studie ${ }^{17}$.

V této práci se ocitáme $\mathrm{v}$ oblasti slezské panovnické diplomatiky pozdního středověku. Existuje zde množství studií, které jsme mohli využít, jakkoliv naprostá většina $\mathrm{z}$ nich se týká 13 . století a do následujícího věku jich proniká jen málo ${ }^{18}$.

Několik slov zaslouží pramenná základna. Slezské archivy totiž utrpěly v závěru druhé světové války citelné ztráty, které se dotkly i listinného materiálu měst. Do konce 13. století není problém, nebot' tu je materiál snesen v moderní všem nárokům vyhovující edici Schlesisches Urkundenbuch - použity byly svazky čtyři až šest ${ }^{19}$. Pro období po roce 1300, kam spadá naprostá většina zkoumaného materiálu, bylo třeba kombinovat velké množství edic různého stáří a kvality ${ }^{20}$.

Lüttich in den Jahren 1345-1348, Folia diplomatica 2, 1976, s. 115-128; V. Va š k ů, Panovnické konfirmace pro moravské kláštery v 18. století. Novověké úřední revize středověkých a raněnovověkých listin, Brno 1981; nověji k tématu od té h o ž autora: Taxy za konfirmační listiny pro moravské kláštery v 18. století, v: Sto let od narození profesora Jindřicha Šebánka, Brno 2000, s. 185-192; Panovnické konfirmační listiny pro město Brno z let 1633-1720, Brno v minulosti a dnes 21, 2008, s. 401-443; R. Vo t a v o vá, Konfirmace městských privilegií na Moravě v 18. století, Jihomoravské okresní archivy 1983, s. 36-39; t a táž, Konfirmace privilegií města Jihlavy v 18. století, Vlastivědný věstník moravský 35, 1983, s. 292-301; M. C a fourková, Konfirmace privilegii města Ivančic ze 17. a 18. století (Novověké revize středověkých a raně novověkých listin), Sborník archivních prací 40, 1990, s. 397430; J. K a h u d a, Panovnické konfirmace privilegií českých klášterů v 18. století, Paginae historiae 9, 2001, s. 30-70.

16 P. B a r, Królewskie konfirmacje majątków ziemskich dla wrocławskich mieszczan z 1420 roku, Śląski Kwartalnik Historyczny Sobótka 69, 2014, č. 3, s. 139-160.

17 Jde jednak o kratší článek: T. Ve 1 i č k a, Zeměpanské konfirmační listiny pro česká a slezská města do roku 1420, Historia Slavorum occidentis 7, 2014, č. 2, s. 194-214, jednak o disertační práci T. Veli č k a, Zeměpanské konfirmační listiny pro česká a slezská města do roku 1420 (srov. pozn. 1).

18 R. Że re lik, Dokumenty i kancelarie książąt głogowskich 1250-1331, Wrocław 1988; W. Ir g a n g, Das Urkunden- und Kanzleiwesen Herzog Heinrichs III. (I.) von Glogau $(+1309)$ bis 1300. Zu einer Untersuchung von Rościsław Żerelik, Jahrbuch der Schlesischen Friedrich-Wilhelms-Universität zu Breslau 28, 1987, s. 51-67; t e n t ý ž, Das Urkunden- und Kanzleiwesen Herzog Heinrichs IV. von Schlesien (1270-1290), Zeitschrift für Ostforschung 36, 1987, s. 1-51 (otištěno také v: tentýž, Schlesien im Mittelalter. Siedlung-Kirche-Urkunden. Ausgewählte Aufsätze, Marburg 2007, s. 397-446 a 447-462); A. W a ł k ó w s k i, Dokumenty i kancelaria księcia legnickiego Henryka V Grubego, Wrocław 1991 (Acta Universitatis Wratislaviensis, Historia 94); M. H o lá, Vratislavská hejtmanská kanceláŕ za vlády Jana Lucemburského a Karla IV., Praha 2011 (Sborník archivní prací 61, suppl.).

19 Schlesisches Urkundenbuch, t. IV.-VI., vyd. W. Irgang, Köln-Weimar-Wien 1988-1998 (dále jako: SUb).

${ }^{20}$ Silesiacarum rerum scriptores, t. I.-III., vyd. F. W. von Sommersberg, Leipzig 1729-1732 (dále jako: SRS); Codex Germaniae diplomaticus, t. II., vyd. J. Ch. Lünig, Leipzig 1733; Urkundensammlung zur Geschichte des Ursprungs der Städte und der Einführung und Verbreitung Deutscher Kolonisten und Rechte in Schlesien und der Ober-Lausitz, vyd. G. A. Tzschoppe, G. A. Stenzel, Hamburg 1832 (dále jako: USUS); Lehns- und Besitzurkunden Schlesiens und seiner einzelnen Fürstentümer im Mittelalter, t. I.-II., vyd. C. Grünhagen, H. Markgraf, Leipzig 1881-1883 (dále jako: LBUS); Breslauer Urkundenbuch, t. I., wyd. G. Korn, Breslau 1870 (dále jako: BU); Urkundenbuch der Stadt Liegnitz und ihres Weichbildes bis zum Jahre 
Kromě regionálních edic bylo třeba pro listiny vzniklé po roce 1300 užívat svazky slezských regest, které sloužily jako první vodítko pro orientaci nad rozšířením konfirmačních listin. A následně bylo snahou dohledávat plnotextové znění takových písemností. Regesten zur schlesischen Geschichte jsou dovedeny do roku $1342^{21}$. Po tomto datu jsme odkázáni na polské pokračování této edice, které zahrnulo léta $1342-1360^{22}$.

Pro období po roce 1360 jsou k dispozici jen výše uvedené listináře měst, teritorií či věcných skupin, nebo katalogy originálních listin uchovávaných v dolnoslezských $\operatorname{archivech~}^{23}$. Novější pomůcku pro písemnosti uložené v Zelenohorském státním archivu nemáme. Pro oblast Horního Slezska, kromě výše zmíněného těšínského diplomatáře a některých dalších teritoriálních edic ${ }^{24}$, naopak jsou k dispozici poměrně nové regestáře, podchycující písemnosti tamních státních archivů do roku $1450^{25}$.

Z uvedeného výčtu je patrné, že ani tyto pomůcky nepostihly veškerý materiál vydaný pro slezské př́íjemce, v tom zvláště konfirmační listiny, až do roku 1419.

1455, vyd. F. W. Schirrmacher, Liegnitz 1866 (dále jako: UBSL); Urkunden der Stadt Brieg, vyd. C. Grünhagen, Breslau 1870 (Codex diplomaticus Silesiae [dále jako: CDS], t. IX); Urkunden der Stadt Löwenberg, vyd. H. Wesemann, Löwenberg 1885; O. M e in a r d u s, Das Neumarkter Rechtsbuch und andere Neumarkter Rechtsquellen, Breslau 1906; Die Inventare der nichtstaatlichen Archive Schlesiens, Kreis und Stadt Glogau, vyd. K. Wutke, Breslau 1915 (CDS XXVIII); Die Inventare der nicht staatlichen Archive Schlesiens, Kreis Jauer, vyd. E. Graber, Breslau 1930 (CDS XXXV); Th. Lin dner, Aus dem Archive der Stadt Jauer, Zeitschrift des Vereins für Geschichte Schlesiens 9, 1868, s. 84-105; Regesta fontium Saganensium, zprac. A. Górski, B. Grelewicz, Zielona Góra - Żagań 2011; Rechtsdenkmäler der Stadt Schweidnitz, vyd. Th. Goerlitz, P. Gantzer, Stuttgart-Berlin 1939; A. S c h a u be, Urkundliche Geschichte der Gründung und ersten Entwicklung der deutschen Stadt Brieg, Brieg 1934; Listinář Těšínska. Codex diplomaticus Ducatus Tessinensis. Sbírka listinného materiálu k dějinám Těšínského Pobeskydí, t. I., zprac. E. Němec, Český Těšín 1955-1958; Landbuch księstw świdnickiego i jaworskiego, t. I.-III., vyd. T. Jurek, Poznań 2000-2007.

${ }^{21}$ Regesten zur schlesischen Geschichte, t. I.-VI., vyd. C. Grünhagen, K. Wutke, E. Randt, Breslau 1866-1930 (dále jako: SR).

${ }^{22}$ Regesty śląskie, t. I.-V., red. W. Korta, Wrocław 1975-1992 (dále jako: RŚl). Především v prvních svazcích jde však o edici značně mezerovitou, kde byla provedena neúplná excerpce pramenů, stejně jako nedodržovány některé metodologické zásady (viz recenze A. G ą s i o r o w s k é h o, v: Studia Żródłoznawcze 22, 1977, s. 264). Ačkoliv bylo na tyto nedostatky $\mathrm{v}$ př́íslušných statích upozorňováno, ani $\mathrm{v}$ dalších svazcích nedošlo $\mathrm{k}$ výraznější nápravě. Důležité doplňky také z hlediska listin pro města obsahují recenze tehdejšího vratislavského archiváŕe E. K o b d z a j e, recenze k prvnímu svazku viz Archeion 69, 1979, s. 336-346; ke druhému svazku viz Archeion 80, 1986, s. 239-256. Např́klad do druhého svazku vyšedšího roku 1983 nebyly zahrnuty archiválie navrátivší se z tehdejší NDR do Vratislavského státního archivu již roku 1980 (k revindikaci viz E. K o b d z a j, Archiwalia śląskie przekazane Archiwum Państwowemu we Wrocławiu z Niemieckiej Republiki Demokratycznej, Archeion 84, 1988, s. 157-166; W. I r g a n g, Verschollene Urkunden wieder in Breslau, Jahrbuch der schlesischen Friedrich-Wilhelms-Universität zu Breslau 23, 1982, s. 293-296).

${ }^{23}$ Katalog dokumentów przechowywanych w archiwach państwowych Dolnego Śląska, t. I.-VIII., zprac. R. Stelmach, R. Żerelik, Wrocław 1991-1998 (dále jako: KDPAPDS).

${ }^{24}$ Např́klad: Die Inventare der nichtstaatlichen Archive Schlesiens, Stadt Neisse, vyd. E. Graber, Breslau 1933 (CDS XXVI); S. K o s z y k, Dokumenty pergaminowe Archiwum Miejskiego w Opolu, Ślaski Kwartalnik Historyczny Sobótka 5, 1950, s. 91-125.

${ }_{25}$ Regesty listin uložených v Horním Slezsku. Regesty dokumentów przechowywanych na Górnym Śląsku, t. I.-II., Wrocław-Opole-Katowice-Opava 2004-2011 (dále jako: RDPGŚ). 
Po roce 1360 bylo třeba užít jmenované Katalogy, ty ovšem zachytily jen originálně dochované písemnosti. Během mých pobytů na Vratislavské universitě mi byl prof. Rościsławem Żerelikem umožněn př́stup k lístkovému katalogu, který byl připravován již německými editory a posléze jejich polskými následovníky pro pokračování projektu slezských regest po roce $1360^{26}$.

Tolik k edicím, z nichž jsem během mé práce čerpal. Letmý přehled naznačil, že zdaleka ne vše, co bylo potřeba, šlo dohledat v plnotextových edicích. Ve velké míře jsem musel probírat přímo př́íslušné městské fondy - nejen, co se týče originálních listin, ale také kopiářů a novověkých kopií. Excerpoval jsem příslušné fondy ve Státním archivu ve Vratislavi ${ }^{27}$, v Opoli ${ }^{28}$ a Zelené Hořre ${ }^{29}$.

\section{KONFIRMAČNÍ LISTINY OBECNĚ}

\section{Charakteristika konfirmačních listin}

V této studii chci představit konfirmační listiny, jejichž př́ijemci byla slezská zeměpanská města. $Z$ př́jemeckého pohledu se zde orientuji na města, jejichž pánem byl suverén toho kterého území. Ohraničení př́ijemecké skupiny nečiní výraznější obtíže. Ve Slezsku jde o města knížecí, popř. královská, jež ležela v knížectvích pod prrímou vládou českého krále. $Z$ pozice vydavatelů potom zkoumám potvrzovací listiny, jejichž vydavatelem byl zeměpán toho kterého území. Je tak nutné sledovat jako vydavatele jak slezská knížata, tak české krále včetně královských hejtmanů v knížectvích přímo podléhajících českému králi.

Několik slov zasluhuje ještě geografický záběr práce. Stranou ze známých důvodů ponechávám města opavského knížectví (Opavsko se v té době řadilo ještě $\mathrm{k}$ Moravě), přesněji řečeno pouze Opavu, nebot' jen ta byla v předhusitském období prŕíjemcem zeměpanských konfirmačních listin.

Konfirmační neboli potvrzovací listiny jsou takovým druhem listin, v nichž jejich vydavatel potvrzuje, prodlužuje nebo obnovuje př́ijemci platnost nějaké právní skutečnosti nebo listiny ${ }^{30}$. Mezi jednotlivými slovesy (potvrzovat, prodlužovat, obnovovat) jsou někdy hledány jisté nuance a obsahové odlišnosti. Nejčastěji identifikujeme potvrzovací listiny podle typických obratů v dispozici - tedy užitých sloves confirmare, approbare, innovare, ratificare, ratum et gratum habere; v německých listinách jsou

${ }^{26}$ Materiál, resp. jednotlivé lístky (bud' strojopisně anebo rukopisně popsané), se nacházejí ve formě kartiček v jednoduchých krabicích, uspořádány zhruba chronologicky, ale nikým doposud nezpracovány. Obsahují excerpty z edic, různých slezských archivů, včetně opisového dochování (kopiáře, různá repertoria, soupisy privilegií). Do jaké míry jsou tyto př́ípravné práce kompletní, není snadné říci. V několika př́ípadech jsem ale narazil na písemnosti, které byly podchyceny na základě méně původního dochování, než jaké je jinak k dispozici. V každém príípadě jsem ale přehlédl zhruba 20000 lístků s regesty písemností a o několik desítek položek jsem rozšírili také množství nalezených zeměpanských konfirmačních listin. Vesměs se jednalo sice jen o zmínky v archivních repertoriích a původní originály zanikly (za 2. světové války), ale i taky bylo toto rozšíření velmi cenné.

27 Archiwum Państwowe we Wrocławiu (dále jako: AP Wrocław).

28 Archiwum Państwowe w Opolu.

${ }^{29}$ Archiwum Państwowe w Zielonej Górze.

${ }^{30}$ L. M a r tín k o vá, Zeměpanské konfirmační a konsensní listiny, s. 14. 
to potom jejich odpovídající překlady: bestetigen, erneuern, confirmiren, ratificiren. Název právního potvrzovacího aktu se také někdy objevuje v eschatokolu, obvykle v koroboraci, kdy daná listina může být latinsky označena jako confirmatio, ratificatio, approbacio nebo odpovídajícími německými výrazy odvozenými od výše uvedených sloves. Vydavatel potvrzovací listiny může konfirmovat různé skutečnosti: nejčastěji to jsou právní akty učiněné jeho předchůdci, ale také právní akty jiných osob, sebe samého, či provedené př́ijemcem.

\section{Konfirmační řízení}

Na následujících řádcích bude nastíněn vznik potvrzovacích listin počínaje důvody a motivy pro jejich vydání, přes povinnost či naopak dobrovolnost jejich potvrzování jak ze strany vydavatele, tak potenciálních př́ijemců. Následovat bude samotný proces zlistinění a hotový listinný produkt ${ }^{31}$.

Ve středověké právní teorii existovaly dva názory na potvrzování listin a obecně na délku platnosti středověkých písemností privilegiálního charakteru. Stály tu proti sobě dvě protiřečící si tendence. V praxi se ale prosadila ta, podle níž bylo jistější nechat si potvrdit privilegia od nově nastoupivšího panovníka, než se jen spoléhat na právní účinnost listin vydaných jeho předchůdci.

Nelze jednoznačně říci, zda potvrzování starších výsad bylo po změně na trůnu povinností32, jak tomu chtěl nikdy v platnost nevstoupivší zákoník Karla IV. Maiestas Carolina v 117. kapitole nazvané De bonis claustralibus ${ }^{33}$. Stejná myšlenka se objevuje již o 200 let dříve v listině Friedricha Barbarossy pro klášter Georgenberg u Goslaru. Panovník zde klášteru vyčítá, že se dostatečně nestaral o panovnické konfirmace svých práv a tím měla být poškozena klášterní práva k jeho majetkům ${ }^{34}$. Dá se říci, že především př́ijemce byl zainteresován na potvrzení jemu náležejících práv panovníkem. Pro moravské konfirmace lucemburské doby konstatovala Lenka Martínková, že až u tř́ čtvrtin všech konfirmací vycházela iniciativa ze strany příjemce ${ }^{35}$. Podobný stav u potvrzení pro řŕšská města seznal také Dirk Hewig ${ }^{36}$. Pravdou je, že na sklonku středověku byla neexistence potvrzení vlastních privilegií stran předchozích panovníků chápána jako deficit ${ }^{37}$. Dlouhé řady panovnických konfirmací začínají u ř́ršských měst zhruba od poloviny 13 . stoletín $^{38}$.

31 Schéma v zásadě odpovídá čtyřem fázím průběhu konfirmačního řízení tamtéž, s. 169173. Ke vzniku písemností a zároveň vystavování listinných potvrzení v Malopolsku, viz $\mathrm{S}$. K u r a ś, Przywileje prawa niemieckiego miast i wsi małopolskich XIV-XV wieku, Wrocław 1971, s. 82-92.

${ }^{32}$ L. M a rtín k o vá, Zeměpanské konfirmační a konsensní listiny, s. 164, se k této eventualitě staví spíše negativně.

${ }^{33}$ B.-U. H e r g e m ö 11 e r, Maiestas Carolina. Der Kodifikationsentwurf Karls IV. für das Königreich Böhmen von 1355, München 1995, s. 218.

${ }^{34}$ Monumenta Germaniae Historica, diplomata regum et imperatorum Germaniae, t. X., p. I.: Die Urkunden Friedrichs I. 1152-1158, Hannover 1975, č. 10; viz též H. K r a u s e, Die Rolle, s. 405.

${ }^{35}$ L. M a rtín k o vá, Zeměpanské konfirmační a konsensní listiny, s. 155.

${ }^{36}$ D. H e w i g, Kaiserliche Bestätigungen, s. 22-23.

37 J. P a u s e r, Privilegienkonfirmation, s. 300.

38 D. H e w i g, Kaiserliche Bestätigungen, s. 15-17. 
Panovník tak z potvrzení práv jistého př́jemce mohl vytěžit vlastně pouze finanční výnos, jak uvádí Lenka Martínková39 ${ }^{3}$ Bylo by však chybou takto omezovat možnost využití takové situace ze strany panovníka. Jak před nedávnem prokázal Peter Brun, právě poskytnutí, nebo potvrzení privilegií bylo pro panovníka dobrou př́ležitostí inscenovat se jako svrchovaný panovník, byla to př́iležitost $\mathrm{k}$ představení svého panovnického potenciálu. Tento rozměr konfirmací pak ke slovu přicházel třeba během událostí v Aargau roku 1415, kdy byl na Friedricha IV. Habsburského uvržen acht a ř́mský král Zikmund se rozhodl vystavit konfirmace pro některá aargauská maloměsta, aby tak prezentoval svou svrchovanou moc a ukázal svou sílu nevěrným městům, která zůstávala na Friedrichově straně ${ }^{40}$.

Vydání konfirmace nemusela vyvolat jen změna panovníka, ale také změna jeho statusu - ve středověké říši nejčastěji římská korunovace. Mluvila o tom Zlatá bula, ale konfirmace, resp. obnovení, jak rríká jeden z jejích předpisů, vydávané po císařské korunovaci příjemcům, kteří disponovali potvrzením práv již dřívější doby od stejné osoby, nacházíme již dříve. Někdy se již u příležitosti první konfirmace (z titulu římského krále) objevuje $\mathrm{v}$ takové listině slib, že k novému potvrzení privilegií dojde po císařské korunovaci. Podobné sliby prricházely u pretendentů trůnu ${ }^{41}$. Př́íkladů ze slezského prostředí pro konfirmace uvedené v život těmito okolnostmi je mnoho. $\mathrm{V}$ nástupu nového panovníka $\mathrm{v}$ zásadě spočívaly důvody vydání konfirmace Jindřicha V. pro Vratislav roku 1290. Okolnosti jejího vystavení však byly blíže specifikovány, nebot' k potvrzení práv došlo teprve poté, co mu město složilo slib věrnosti ${ }^{42}$. Nástup nových panovníků byl př́ičinou vystavení několika konfirmací pro Vratislav v letech 1310-1311, které reagovaly na změny v osobách vládnoucích knížat: nejprve to totiž byli bratři Jindřich VI. a Boleslav III. ${ }^{43}$, záhy se k nim přidal i třetí sourozenec Vladislav ${ }^{44}$, aby krátce na to došlo k definitivnímu podílu, kdy vratislavské knížectví i s městem Vratislaví připadlo Jindřichu VI. ${ }^{45}$ Stejnou prríčinu evidujeme také u konfirmací pro Lehnici ve 40. letech 14. století, když Boleslav III. postoupil počátkem tohoto decénia vládu v knížectví svým synům. Ti ihned po jejím převzetí roku 1342 potvrdili nejdůležitějšímu městu v regionu Lehnici - jeho privilegia ${ }^{46}$. Ale změn v lehnickém knížectví nebylo dost. Krátce se jako samostatný vládce prosadil roku 1345 Ludvík I., ale ten již o rok později odstoupil svou část knížectví - tehdy započal spor mezi bratry, který skončil až roku $1357^{47}$. Tyto změny nalezly svůj odraz i ve vydávání potvrzovacích listin: roku $1345 \mathrm{k}$ jejímu vyhotovení přistoupil Ludvík ${ }^{48}$, o rok později Václav ${ }^{49}$, který se zde tehdy prosadil jako samostatný vládce. Nicméně zdaleka ne v každém knížectví

\footnotetext{
${ }^{99}$ L. M a rtín k o vá, Zeměpanské konfirmační a konsensní listiny, s. 164.

${ }^{40}$ P. B r u n, Von Sinn und Unsinn, s. 169-179.

${ }^{41}$ D. H e w i g, Kaiserliche Bestätigungen, s. 19.

42 SUb V., č. 461.

${ }^{43}$ BU č. 88.

44 BU č. 89.

45 BU č. 93.

${ }^{46}$ Legnica. Monografia historyczna miasta, red. M. Haisig, Wrocław 1977, s. 20.

47 Tamtéž, s. 21-22.

${ }^{48}$ UBSL č. 140.

${ }^{49}$ UBSL č. 145.
} 
se postupovalo tímto způsobem (pokud jde o emise konfirmací), jak se o tom níže ještě zmíníme.

Další př́iležitostí k vydání konfirmace bylo smíření s městem, v případě říšského prostředí bývalo často spojeno se zrušením vyhlášeného achtu ${ }^{50}$. Např́iklad roku 1219 se Friedrich II. smiřuje se Štrasburkem a slibuje jej zachovávat při starých právech. Zajímavá je listina Václava IV. z roku 1381, v níž znovu uvádí v platnost všechna práva štrasburských měšt’anů. Důvodem k jejich zneplatnění bylo jejich předchozí přechovávání do klatby uvrženého Hartmanna Roteho z Basileje ${ }^{51}$. Takový důvod přichází i u slezských měst. Jako př́klad lze uvést konfirmaci Boleslava III. Lehnicko-Břežského pro Goldberk z roku 1341 po ukončeném sporu s městem, které se zpěčovalo zaplatit vévodovi částku nad rámec obvykle odváděných daní ${ }^{52}$. Spor s městy svého knížectví musela v závěru 80. let 14. století urovnávat Anežka Svídnická - na konci nesvárů bylo smíření a vydání konfirmační listiny ${ }^{53}$.

Podnětem k vydání konfirmační listiny mohly být i problémy s pečetí vydavatele ${ }^{54}$, ale $\mathrm{s}$ tím se ve studované slezské materii nesetkáváme.

V̌̌echny dosud vyjmenované důvody a podněty vydání konfirmací stály mimo rámec vlastního města, které na jejich načasování a průběh nemělo žádný vliv; byt' samozřjejmě iniciativu směřující $\mathrm{k}$ vydání konfirmace $\mathrm{v}$ důsledku drželo ve svých rukou. Existovaly ale také okolnosti, které mohla vyvolat situace nastalá v samotných městech. Častým důvodem byla bud' ztráta, nebo poškození privilegií - nezřídka v souvislosti s požárem města. Tak tomu bylo u celé řady konfirmací. Požáry tu bývaly častými a nevítanými hosty a nezř́idka pod jejich plameny lehlo popelem celé město, nebo jeho část. Listinné archivy bývaly umist’ovány v kamenných domech či věžích, ale zkáze častokrát neušly ${ }^{55}$. Příčinou vydání konfirmace pro slezský Kožuchov v roce 1419 byl městský požár a škody, které město utrpělo, i když není zmíněno, zda došlo i ke zničení listin. Listiny tu nejsou inserovány, ale jednotlivá práva vyjmenována, což by této domněnce nasvědčovalo ${ }^{56}$. Roku 1369 byla kněžna Anežka Svídnická žádána Svídnickými o obnovení dlužního úpisu týkajícího se dlužné částky po jejím zemřelém muži, který als daz her yn vorterben und czu nichte worden were ${ }^{57}$.

Konečně vystavení konfirmační listiny mohlo být vyvoláno konkrétními potřebami či ohrožením města $\mathrm{v}$ některé z právních oblastí. Nalézáme i takové konfirmace, kde základem pro jejich vydání byla stížnost měšt’anů panovníkovi. Patří sem zmíněná konfirmace Anežky pro Svídnici z roku 1369, kde si Svídničtí také stěžovali (clageten clagelich) na zánik uvedené listiny ${ }^{58}$.

${ }^{50}$ D. H e w i g, Kaiserliche Bestätigungen, s. 20.

51 Tamtéž.

52 SR č. 6523.

53 CDS XXVII., s. 180-181, č. 14.

${ }^{54}$ D. H e w i g, Kaiserliche Bestätigungen, s. 21-22.

${ }_{55}$ R. Ż e re li k, Inwentaryzacja dokumentów w średniowiecznych archiwach śląskich, v: Inter laurum et olivam, Praha 2007 (Acta Universitatis Carolinae, Philosophica et historica 2002, 1/2. Z pomocných věd historických 16), s. 47-54.

${ }^{56}$ AP Wrocław, rep. 132a, dep. miasta Kożuchowa, č. 6; reg.: CDS XXIV., s. 132, č. 6.

57 Landbuch I., č. 396.

58 Tamtéž. 
Typický průběh konfirmačního řízení obvykle začínal suplikou budoucího příjemce. Mohla být přednesena ústně nebo písemně. Obojí je z narací potvrzovacích listin doloženo. Jen $\mathrm{v}$ jediném př́padě, roku 1343 u Vratislavi, je doloženo jméno měšt’ana, který supliku předkládal. Tím, kdo ji králi, nepochybně sepsanou, přinesl, byl vratislavský měštan Tylo z Lehnice ${ }^{59}$. Supliky se opravdu objevují často, vůbec nejčastěji v konfirmacích vystavených českými králi, at' už šlo o Vratislav ${ }^{60}$, ale také Javor $^{61}$, či Gryfów ${ }^{62}$.

Pokud se v naraci listiny hovoří o suplice, vesměs je jasné, že se jednalo o zástupce města, kteří jsou v té souvislosti obvykle jmenováni. Ne zcela zřetelná situace je jen u dvou konfirmací stejné věci pro Svídnici z roku 1374, kde není jisté, došlo-li k jejich vystavení na žádost Anežky Svídnické, nebo města samého ${ }^{63}$.

Jak takové supliky vypadaly? Zde narážíme na naprostou torzovitost pramenů. Někdy si město mohlo pořídit před cestou ke královské audienci soupis listin, které žádalo potvrdit. Takový soupis je zachován ze Svídnice z roku 1504. Šlo o písemnosti vzaté s sebou tehdy městským poselstvem do Uher, na Vladislavův dvůr do Budína. Vyslanci s sebou pravděpodobně nesli originály, na radnici byl pro kontrolu ponechán jejich soupis. Obsahuje jen jednu konfirmační listinu, dá-li se soudit ze stručných regestů, a to krále Vladislava Jagellonského ${ }^{64}$.

V předkládání nebo přednášení suplik se průběh vydání konfirmačních listin v zásadě nelišil od žádostí na vydání jakéhokoliv jiného privilegia. Specifikem vzniku potvrzovací listiny bylo to, že potvrzovaný kus byl, nebo alespoň měl být, vydavatelem či jeho úředníky prohlédnut, zda je možné potvrdit jeho platnost ${ }^{65}$. Ve středověké rríši vesměs nebylo nutné předkládat originál listiny, kterou chtěl její příjemce potvrdit. Ten bylo třeba předložit až tehdy, vzbudil-li její vidimus podezření6 ${ }^{6}$.

Pro české, moravské ani slezské městské prostředí nelze rozhodnout, jaký způsob byl závazný nebo obvyklý. Zřejmě ale bylo přijato, pokud to bylo možné, přinášet originály písemností ${ }^{67}$.

Jen málo se lze v naracích listin setkat s bližší charakteristikou, v jaké formě byly potvrzované kusy vydavateli předkládány. Opakovaně zaznívá obrat, že daná písemnost byla prostě přinesena. Více se dozvídáme např. u listiny pro Břeh, v níž Břežští žádajíce o potvrzení, přinesli roku 1324 Boleslavu III. „knihu, do které byla

59 BU č. 177.

${ }^{60}$ BU č. 125, 190; AP Wrocław, Dokumenty miasta (dále jako: DM) Wrocławia, č. 992, 1167, 12586, 992.

${ }^{61}$ CDS XXXV., č. 55.

${ }^{62}$ AP Wrocław, AM Jeleniej Góry, vidimus z roku 1655.

${ }^{63}$ AP Wrocław, DM Świdnicy, U 231 (též v Aktach miasta [dále jako: AM] Świdnicy 411, f. 3v-6r); AM Świdnicy 411, f. 6r-8r.

${ }^{64}$ AP Wrocław, DM Świdnicy, U 5171.

${ }^{65}$ D. H e w i g, Kaiserliche Bestätigungen, s. 26.

66 Tamtéž, s. 25; H. B r e s s 1 a u, Handbuch der Urkundenlehre, t. II., Leipzig 1915, s. 28.

${ }^{67}$ Jinak by totiž těžko vzniklo v prostředí nejvýznamnějšího českého šlechtického rodu za Oldřicha II. z Rožmberka falzum, které mělo tento rod privilegovat nad ostatní tím, že při potvrzení mohou předkládat jen inserty listin. Viz R. Š i m ů n e k, R. L a vi č k a, Páni z Rožmberka 1250-1520. Jižní Čechy ve středověku. Kulturněhistorický obraz šlechtického dominia ve středověkých Čechách, České Budějovice 2011, s. 135. 
vepsána všechna jejich práva“688. Nejasná je např́iklad forma, v níž byly Vratislavskými roku 1400 předneseny před Václavem IV. ,Zvyk a ustanovení od starodávna užívanéc týkající se reglementace prodeje sukna ve městě ${ }^{69}$. Nejspíš ale toto sepsání zvyků nemělo listinnou formu. Jinak tomu bylo v př́padech, kdy potvrzované kusy v originálech již neexistovaly. Tehdy se předkládaly bud' opisy ${ }^{70}$, nebo se vydavatel musel o jejich obsahu informovat jinak, nespoléhaje se jen na informace petentů.

Mohlo se stávat, že město vyslalo panovníkovi koncept konfirmační listiny v takovém případě byla zkoumána její shodnost s „,Vorurkunden“71.

Předložené písemnosti k potvrzení, at’ už to byly originály nebo opisy, měly být v ideálním prrípadě prohlédnuty vydavatelem, nebo některým z vyšších představitelů jeho kanceláře. Bohužel máme vcelku málo informací o způsobech kontroly takových písemností a to nejen ve slezském měřítku, ale i šířeji středoevropském ${ }^{72}$. Zkoumání listiny nejspíš bývalo jen povrchní, omezuje se pouze na bližší ohledání pečeti ${ }^{73}$. Ve zkoumaných konfirmačních listinách lze v několika případech narazit na obecnější nebo podrobnější zmínky o přezkoumávání listin. Zajímavé je, že téměř ve všech případech, kdy něco takového přichází, je také inserována potvrzovaná listina. Insertní konfirmace zpravidla ve studovaném materiálu nepřevládaly (nebo netvořily absolutní většinu), jak o tom ještě budu hovořit. Ale nyní již ke konkrétním zmínkám středověké listinné kritiky.

Konfirmace pro slezskou Lehnici z roku 1380, kterou vydal vévoda Ruprecht, v sobě skrývá několik informací o zkoumání předložené listiny. Lehničtí tu předložili předchozí všeobecnou konfirmaci vévody Václava I., která, jak nás zpravuje narace, nebyla nijak poškozena ani nebudila jakékoliv podezření. Byla zpečetěna otcem vévody Ruprechta, knížetem Václavem I. Šlo o velkou pečet' zavěšenou na červeno-zelených provázcích ${ }^{74}$. Ve dvou dalších prrípadech se setkáváme s tím, že byla vydavateli listina daná k potvrzení alespoň přečtena. Jiné další úkony zaznamenány nebyly. Jednalo se o konfirmace dvou svídnicko-javorských hejtmanů. Nejprve roku 1399 Beneš z Choustníka tímto zpo̊sobem potvrdil městu Boleslavec listinu Jindřicha Javorského ${ }^{75}$. Druhý př́klad pochází z roku 1407, kdy Jan Krušina z Lichtenburka potvrdil městu Lemberk hned několik listin. Na rozdíl od všech předchozích tu nebyly inserovány. Byl tu však podán jejich poměrně podrobný výtah ${ }^{76}$. Poslední listina, o které se v této souvislosti zmíním, je další všeobecná konfirmace pro Lehnici - tentokrát od Václava II. Lehnického z roku 1409. Obrat vztahující se k potvrzovanému kusu je tu ale téměř stejný jako při předchozí všeobecné konfirmaci roku 1380, takže je tu

${ }^{68}$ USUS č. 125: eyn buch, do inne geshribet stunden alle sy recht.

${ }^{69}$ AP Wrocław, DM Wrocławia, č. 992: ein gewonheid und saczunge von alders gehabt.

${ }^{70}$ Konfirmace pro Nové Město pražské od Zikmunda roku 1436, viz Codex iuris municipalis regni Bohemiae, t. I: Privilegia měst pražských, vyd. J. Čelakovský, Praha 1886, č. 141.

${ }^{71}$ D. H e w i g, Kaiserliche Bestätigungen, s. 28.

${ }^{72}$ H. B r e s s l a u, Handbuch, t. II., s. 29.

73 Tamtéž.

${ }^{74}$ UBSL č. 313.

${ }^{75}$ Landbuch III., č. 760.

${ }^{76}$ Urkunden der Stadt Löwenberg, č. 30. 
těžko rozhodnout, zda skutečně zrcadlí reálný průběh konfirmačního řízení, nebo zda došlo k pouhému převzetín ${ }^{77}$.

Uvedené př́ílady dokazují, že prohlídka potvrzovaných listin asi nebyla úplně běžnou součástí konfirmačního řízení, nebo alespoň nemáme informace o opaku. Musíme se tu spoléhat na samotnou dikci listin, které jsou bohužel v tomto ohledu mimořádně skoupé. Ale i z nečetných zmínek vyplývá, že kontrola listin, pokud vůbec přicházela, se zpravidla omezovala na zkoumání pečeti, nebo obecně vnějších znakư ${ }^{78}$. Spíše z prostředí české královské kanceláře lucemburské doby je známo, že potvrzované listiny byly před vydavatelem čteny. Tehdy mohl sám nejlépe posoudit, zda je znění př́slušné listiny hodno potvrzení. Snad př́liš nepochybíme, když budeme předpokládat, že alespoň v kanceláři k četbě př́islušných písemností předkládaných ke konfirmaci docházelo. Těžko si představit, že by se panovník dobrovolně vzdával tohoto poměrně důležitého správního instrumentu. To, že se při konfirmačním procesu v prvé řadě přihlíželo $\mathrm{k}$ pečeti potvrzovaných listin, dokládá výše vyjádřenou domněnku, že běžnější bylo ke konfirmaci přinášet přímo originály písemností, které petent žádal potvrdit ${ }^{79}$.

$\mathrm{Na}$ formulář konfirmačních listin měly v mnoha př́padech vliv předchozí zeměpanské potvrzovací listiny, které se nacházely v městských archivech ${ }^{80}$. Je to patrné např́iklad na konfirmacích pro Lehnici během 14. století. Velmi se rovněž podobají všeobecné konfirmace českých králů pro Vratislav. Četné styčné body se však nacházejí porůznu i jinde. Těmito otázkami se ale budu obírat v samostatné části věnované rozboru listinného formuláře konfirmací.

Vliv potvrzovaných listin se pravděpodobně odrážel i na jazyku konfirmačních listin. Nejspís tak si lze totiž vysvětlit, že se v nich déle než v ostatním listinném materiálu udržuje latina. Pro slezská města platí, že němčina do jejich konfirmačních listin sice proniká, ale nikoliv takovým tempem jako do jiných zeměpanských listin, jejichž př́ijemcem byla. I k této problematice se ještě podrobněji vrátím.

Po polovině 14. století se mohl do procesu vzniku konfirmace vydané českým králem vsunout ještě relátor, který zprostředkovával př́kaz ke zlistinění uzavřený $\mathrm{v}$ panovnické radě, ale tento postup se stal běžnou praxí zřejmě až v kanceláři Václava IV. ${ }^{81}$

Stejně jako za každou jinou písemnost privilegiálního charakteru musel i u konfirmace př́ijemce odvést př́ślušnou částku. Nejednalo se jen o částku (kancelářskou taxu) přímo za listinu, nýbrž náklady bývaly daleko širší: především pokud šlo

77 AP Wrocław, DM Legnicy, č. 226; regest: UBSL č. 438.

78 Stejné zjištění přináší i L. Martín k o vá, Zeměpanské konfirmační a konsensní listiny, s. 161-162.

${ }^{79}$ V některých př́padech je doloženi o použití register. Viz I. H 1 a v á č e k, Die Luxemburger und die böhmischen königlichen Städte des 14. Jahrhunderts im Lichte ihres Privilegiengutes, v: Die Stadt als Kommunikazionsraum. Beiträge zur Stadtgesellschaft vom Mittelalter bis ins 20. Jahrhudert. Festschrift für Karl Czok zum 75. Geburtstag, Leipzig 2011, s. 424.

${ }^{80}$ Nelze tak souhlasit s názorem L. M a r tín k o v é, Zeměpanské konfirmační a konsensní listiny, s. 162, že př́jemce nebyl schopen nějakým zásadním způsobem ovlivnit podobu a rozsah konfirmačního textu. Vedle toho předchozí konfirmace často ovlivňovaly i jazyk následujících potvrzovacích listin viz dále.

81 Tamtéž, s. 171. 
o kancelářské úředníky, kteří se na listině nějak podíleli, či dvořany, kteří pomohli vydání listiny zprostředkovat. Výše kancelářských tax je známa především pro říšská města, kde se leckde zachoval příslušný účetní materiál, jenž tuto informaci přinášín ${ }^{82}$. Pro české korunní země známe výši částek za obdržená privilegia u hornolužického Zhořelce ${ }^{83}$. Už z nich je patrno, že poplatky pro domácí města bývaly nižší úměrně jejich menšímu významu a bohatství (i když právě Zhořelec se mohl měřit s říšskými městy střední velikosti). Svědčí o tom i dochovaná suma za udělení výročního trhu městu Stř́ibro roku 1390, která činila 7 kop grošŭ ${ }^{84}$. Jsou známy obnosy na vyhotovení potvrzovacích listin pro některá moravská města: roku 1350 zaplatili Brněnští Janu Jindřichovi 27 hřiven grošů, roku 1421 odvedli Znojemští kanceláři Zikmunda Lucemburského 19,5 hřivny ${ }^{85}$. V této záležitosti ještě nebyl prováděn soustavný výzkum, jakkoliv již ted' je jasné, že by se jednalo o časově velmi náročnou záležitost $\mathrm{s}$ ne úplně jistým výsledkem. Pro slezská města nejsou k dispozici potřebné prameny pro poznání výše poplatků za vydávané listiny včetně konfirmací.

\section{Konfirmace a jejich dělení}

Podle obsahu se rozlišuje několik druhů potvrzovacích listin ${ }^{86}$. Dvě základní skupiny představují insertní nebo bezinsertní konfirmace. Rozdíl spočívá v tom, zda je potvrzovaná listina do konfirmace opsána (inserována) nebo nikoliv. Existovalo mezi nimi ale samozřejmě více mezistupňů, kdy listina nemusela být opsána celá, ale pouze citovány její nejvýznamnější části, stejně jako se lze setkat s obsahovým výtahem. Tyto mezistupně jsou častější pro konfirmace právních aktů učiněných samotným městem, i když tím nemá být řečeno, že u potvrzení panovnických privilegií vůbec nepřicházejí. Někdy dokonce můžeme narazit na vícenásobný insert, kdy v inserované listině samé je inserována některá další.

Až do 10. století nejsou insertní konfirmace vůbec známy. První listina římského císaře (krále), kde byl proveden plný insert potvrzované listiny, pochází od Oty II. z roku $981^{87}$. Plně se inserování rozvinulo pod vlivem sicilské kanceláře v listinách Friedricha II. od roku $1216^{88}$ a od vlády Rudolfa Habsburského se stává převažujícím způsobem konfirmací v řŕšské kanceláři ${ }^{89}$. Mimo královskou (resp. císařskou) kancelář se takový druh konfirmací objevuje poprvé v polovině 12 . století v listinách štrasburského biskupa a salcburského arcibiskupa. Zatímco pro říši

${ }^{82}$ I. H 1 a v á č e k, Urkunden- und Kanzleiwesen, s. 269-289.

83 Tamtéž, s. 288.

84 Tamtéž, s. 287.

${ }^{85}$ R. A n t o nín, T. B o r o v s k ý, Panovnické vjezdy na středověké Moravě, Brno 2009, s. $183,153$.

${ }^{86} \mathrm{~K}$ tomu podrobně viz L. M a r t í n k o v á, Zeměpanské konfirmační a konsensní listiny, s. $14-15$.

${ }^{87}$ H. B re s s 1 a u, Handbuch, t. II., s. 302.

${ }^{88}$ Tamtéž, s. 306; W. Erben, L. S ch mitz-Kallen berg, O. Redlich, Urkundenlehre, t. I., München-Berlin 1907, s. 355.

${ }^{89}$ H. B r e s s 1 a u, Handbuch, t. II., s. 306; M. L a w o, Sprachen der Macht - Sprache als Macht. Urkundensprachen im Reich des 13. und 14. Jahrhunderts (mit editorischem Anhang), v: Die Goldene Bulle. Politik - Wahrnehmung - Rezeption, t. I., Berlin 2009, s. 531. 
o pro moravské prostředí během 14 . století počet insertních konfirmací stoupá a až převažuje ${ }^{90}$, zcela neplatí nárůst tohoto druhu konfirmací pro potvrzovací listiny ani českých ani slezských městských př́ijemců ${ }^{91}$.

Nikdy, ani v Čechách ani ve Slezsku, nedosahovaly insertní konfirmace pro městské př́ijemce výrazné převahy nad konfirmacemi bezinsertními. Již výše bylo uvedeno, že insertní konfirmace byly vnímány jako správnější a transparentnějšš ${ }^{92}$. Praxe si z tohoto pohledu ne vždy brala poučení. Přesto ale jsou doloženy určité náznaky, že i v listinné praxi existovala povědomost o insertních konfirmacích jako správnější variantě. V několika málo bezinsertních konfirmacích se nachází obrat, že potvrzované kusy mají platit, jako kdyby byly inserovány. Evidentně tu prostupuje zvýšená míra důvěryhodnosti v insertní konfirmace ${ }^{93}$.

Velmi častým případem bylo spojování potvrzení listin s udělením nových práv. Takové př́pady se označují jako polokonfirmace ${ }^{94}$. Ke konfirmaci mohly být připojovány vlastně jakékoliv milosti, které mohly být pochopitelně zlistiněny též samostatně. Rozlišení konfirmace a polokonfirmace je nezřídka dosti obtížné. Ne vždy jsou od sebe zřetelně odděleny potvrzované právní akty a nově udělované.

Specifickým př́padem jsou potom tzv. kvasikonfirmace, tedy takové listiny, které určité právo zdánlivě udělují, ale ve skutečnosti jej vlastně potvrzuji ${ }^{95}$. Neboli jinými slovy udělují to, co již př́ijemce dávno má a užívá. Takové listiny je tedy třeba posuzovat nejen podle dispozičních sloves, ale především s ohledem na okolnosti vzniku a pozadí událostí jim předcházející. Někdy mohou pomoci $\mathrm{k}$ identifikaci takové listiny pasáže z narace či dispozice. Praví-li se např́klad v listině Bernarda Svídnického pro Svídnici, že město daná práva již vlastní a přesto jim je vládce uděluje, jde právě o kvasikonfirmaci ${ }^{96}$. Podobné jsou př́pady darování odedávna užívaných městských práv, čili de facto jejich potvrzení či prodloužení platnosti. Ve Slezsku se také vyskytují př́klady udělení již uděleného vydavatelem konfirmační listiny, jak je to doloženo za Jindřicha IV. Vratislavského v listinách pro Vratislav či Grodkov ${ }^{97}$. Všimněme si dalších takových listin. Roku 1326 osvobodil Boleslav III. Břežské od placení knížecích dávek s výjimkou dvou vyjmenovaných a zároveň potvrdil všechna jejich privilegia. Neobjevuje se zde sloveso confirmare ani jiné obdobné, nicméně jde přesto o konfirmaci, nebot' Boleslav stará a odedávna užívaná práva znovu uděluje, čili je de facto potvrzuje ${ }^{98}$. Dále zmiňme listinu, v níž Boleslav Lehnický potvrzuje Goldberku roku 1327 jeho městské právo a slibuje, že nebude

${ }^{90}$ L. M a r tín k o vá, Zeměpanské konfirmační a konsensní listiny, s. 27; D. H e w i g, Kaiserliche Bestätigungen, s. 34.

91 T. Ve li č k a, Zeměpanské konfirmační listiny, s. 193.

92 Pozn. č. 32.

93 AP Wrocław, DM Wrocławia, č. 1061, 1186: das dieselben privilegien, handfesten und briue in allen iren punckten - - gancz und unuorruckt bleiben und gehalden werden sollen gleichweis als ob die selben ire privilegia, handfesten und briue von wort zu wort hierynne eygentlichen geschriben weren.

${ }_{94}$ L. M a r tín k o vá, Zeměpanské konfirmační a konsensní listiny, s. 15.

95 Tamtéž.

96 AP Wrocław, DM Świdnicy, č. 13.

97 SUb IV., č. 282, 284.

98 A. S c h a u b e, Urkundliche Geschichte, č. 31, s. 326-327. 
podporovat nikoho, kdo byl ve městě proskribován ${ }^{99}$. V listině samé se jedná o udělení městského práva, nicméně Goldberk městské právo obdržel již o deset let dříve (tedy alespoň formálně ${ }^{100}$. Kvasikonfirmační listinu obdržely i Świebodzice ve svídnickém knížectví. Bolek Svídnický jim dává odedávna vlastněné městské právo (čili jej vlastně potvrzuje) ${ }^{101}$. Složitým případem je písemnost vydaná Václavem IV. pro Hiršberk v roce $1408^{102}$. Zavádějícím způsobem nás o jejím obsahu informuje Katalog dokumentów $^{103}$. Stojí v něm, že Václav transsumuje listinu Bolka II. Svídnického z 3. června 1348 - týkala se mílového práva. Václav ovšem listinu netranssumoval, nýbrž její obsah shrnul. Je otázka, zda lze listinu považovat za konfirmaci. Jde de facto o znovuudělení obsahu Bolkova mandátu - vlastně o zopakování jeho nařízení. Konfirmační sloveso se nevyskytuje. Na druhé straně v suplice př́ijemce žádá, aby jej Václav u onoho Bolkova práva (zákaz obyvatelům obchodovat mimo trhy) zachoval a znovu je poskytl. Spíše se tedy dá považovat za konfirmaci.

Další hraniční skupinou jsou tzv. konsensní listiny, které Lenka Martínková zkoumala v souvislosti s konfirmacemi, i když odděleně ${ }^{104}$. Od konfirmačních listin se liší, jak je nasnadě, tím, že jejich vydavatel nepotvrzuje, nýbrž dává souhlas k právnímu aktu. Na rozdíl od konfirmací byly často konsensní listiny vydávány ještě před realizací právního aktu, který schvalovaly. K souhlasu ale také mohlo dojít až poté - tehdy se zvláště tyto kusy blíží konfirmacím. Výjimečně také mohly mít podobu mandátu, i když listinná forma převažuje. A přichází ještě jeden významný rozdíl mezi nimi a konfirmacemi. Zatímco konfirmace, jak bylo výše uvedeno, mohly potvrzovat právní skutečnosti uvedené v život různými osobami, konsensní listiny se vždy vztahují k právnímu aktu prováděnému poddanými panovníka. Odpadají tedy takové, které by se vztahovaly k předchůdcům panovníka - s nimi se právě pojila většina konfirmačních listin. $Z$ tohoto důvodu konsensní listiny nechávám stranou.

Samostatnou podskupinu konfirmačních listin tvoří tzv. observační listiny. Ty bývají někdy autory vřazovány mezi potvrzovací listiny a často se mezi observačními a konfirmačními listinami nečiní žádný rozdíl. V observačních listinách jejich vydavatel nepotvrzoval platnost práv či listin, ale sliboval jejich dodržování. Odpovídala tomu i dispoziční slovesa: v latinských listinách observare nebo conservare; v německých písemnostech slovesa behalden, bei rechten lassen apod. Setkáváme se s nimi daleko častěji u slezských než např́íklad u českých měst ${ }^{105}$, což vyplývalo z jejich rozdílného postavení v systému panovnické vlády a v neposlední řadě z jiného správního systému ve Slezsku než v Čechách. Observační formule někdy bývala součástí konfirmačního formuláře, ale nebývalo to př́liš často. Tento druh listin byl pro města vydáván jen v určitých situacích, někdy mohl suplovat klasickou konfirmační listinu ${ }^{106}$.

\footnotetext{
99 SR č. 4626.

100 Viz SR č. 3674

101 USUS č. 149

102 AP Wrocław, DM Jeleniej Góry, č. 53.

103 Viz výše, pozn. 23.

${ }^{104}$ L. M a rtín k o vá, Zeměpanské konfirmační a konsensní listiny, s. 56-78.

105 T. Ve li č k a, Zeměpanské konfirmační listiny, s. 199.

106 Blíže viz tamtéž, s. 199-200.
} 
Klíčovým obsahem konfirmační listiny bylo potvrzení či obnovení nějaké právní skutečnosti. Již výše jsme slyšeli, že se k tomuto dispozičnímu jádru nezřídka připojovala ještě další ustanovení či milosti a vznikaly tak tzv. polokonfirmace. Potvrzovací listiny někdy obsahovaly i další formule, kterými byla jejich ustanovení zdůrazňována a jejich právní síla zvyšována. Nemám zde na mysli sankci jako část listinného formuláře, ale některé speciální obraty, které prŕíslušné listině dodávaly na váze. $\mathrm{V}$ několika prrípadech se lze setkat $\mathrm{s}$ revokačními formulemi v závěru dispozice. Odvolávají se v ní budoucí listiny, které by odporovaly potvrzovaným skutečnostem. Takové obraty jsou známy z některých konfirmací Karla IV. ${ }^{107}$, ale nejstarší doklad čteme v potvrzovací listině Jindřicha V. z roku 1290 pro Vratislav ${ }^{108}$. Dvakrát a v obou př́ípadech v konfirmacích pro slezský Břeh narážíme na ustanovení mající zavazovat také následníky vydavatele k vydání potvrzení privilegií konkrétního př́ijemce. Poprvé byla tato formule zahrnuta do konfirmační listiny vydané městu roku 1292 Jindřichem V. ${ }^{109}$ Podruhé se vyskytla v roce 1324 v konfirmaci Boleslava III. ${ }^{110}$ Ve všeobecné konfirmaci pro Vratislav roku 1348 se objevuje slib panovníka potvrdit listinu danou městu od kohokoliv ${ }^{111}$, přičemž toto ustanovení přešlo i do následných všeobecných konfirmací pro toto město (u Karla IV. i Václava IV.) ${ }^{112}$. Snad ani není třeba zdůrazňovat, že praktický dosah všech těchto ustanovení byl velmi omezený. Ovšem sama jejich existence svědčí o zvýšeném významu těch listin, v nichž se vyskytly.

\section{SLEZSKÉ KONFIRMAČNÍ LISTINY}

\section{Přehledy konfirmačních listin}

Po obecnějším úvodu, který jsem však pro větší instruktivnost doplňoval př́íklady slezských listin, nyní přecházíme k samotné slezské materii. Než se města v regionu mohla stát př́jemci zeměpanských listin a posléze též konfirmací, bylo nutné uplynutí určité doby, kdy došlo k etablování této nové společenské formy v daném prostoru. Geneze slezských měst ${ }^{113}$ spadá do počátku 13. století a hlavní vlna jejich zakládání tu přišla po roce 1241 po mongolském vpádu. V 1. polovině 13 . století vzniklo ve Slezsku cca 25 měst, ve druhé polovině století asi 75. Nejsilnější byl lokační proces v 50. a 60. letech 13. století, vysoké tempo si ale udržel až do roku 1300.

\footnotetext{
107 BU č. 190, 204; AP Wrocław, DM Wrocławia, č. 329.

108 SUb V., č. 461.

109 SUb VI., č. 83.

110 USUS č. 125.

111 BU č. 190.

112 BU č. 204, AP Wrocław, DM Wrocławia, č. 12586 (transsumpt z r. 1614), 639.
}

113 K vývoji slezských měst ve středověku viz W. K u h n, Die deutschrechtlichen Städte in Schlesien und Polen in der ersten Hälfte des 13. Jahrhunderts, Marburg an der Lahn 1968; t e n tý ž, Die Städtegründungspolitk der schlesischen Piasten im 13. Jahrhundert vor allem gegenüber Kirche und Adel, Archiv für schlesische Kirchengeschichte 29, 1971, s. 32-67; 30, 1972, s. 33-69; 31, 1973, s. 1-35; 32, 1974, s. 1-20; M. B o g u ck a, H. S a m s o n ow i c z, Dzieje miast i mieszczaństwa w Polsce przedrozbiorowej, Wroclaw 1986; Schlesisches Städtebuch, vyd. H. Stoob. P. Johanek, Stuttgart-Berlin-Köln 1995 (Deutsches Städtebuch I); nejnověji je třeba zmínit knihu: Die Rechtsstadtgründungen im mittelalterlichen Polen, red. E. Mühle, Köln 2011 (Städteforschung A 81). 
Do roku 1342 ve Slezsku existovalo zhruba 120 měst a městeček. Pro srovnání dodejme, že v podobně rozlehlém Velkopolsku jich bylo jen $52^{114}$. Naprostá většina zakládaných měst ve Slezsku byla zeměpanského původu. Silná byla vedle toho fundační aktivita vratislavských biskupů. Méně častá byla klášterní, neřku-li šlechtická založení. Ze zeměpanských slezských měst se předmětem zájmu v této studií stalo 34 lokalit, které byly př́jemci alespoň jedné potvrzovací listiny vydané př́islušným vládcem.

První konfirmační listiny pro městské př́ijemce se zachovaly, stejně jako v Čechách ${ }^{115}$, ze 70. let 13. století. Až do počátku 90. let byl jejich jediným vydavatelem Jindřich IV. Vratislavský. Směřovaly především do Vratislavi, vedle toho také do Svídnice a Grotkova. Na jeho konfirmační aktivitu navázal v roce 1290 Jindřich V. Tlustý, který se stal dědicem a nástupcem Jindřicha IV. ve větší části jím ovládaných zemí. Do roku 1300 se zachovalo jedenáct konfirmací, což je zcela srovnatelný počet s českým městským prostředím ${ }^{116}$. Do roku 1300 vystupují jako vydavatelé potvrzovacích listin jen Jindřich IV. Probus a Jindřich V. Tlustý. Až na počátku nového století k nim přistupují další. Kromě počtu vydavatelů stoupá v té době také množství př́ijemců - jsou mezi nimi nově města zaháňského, ratibořského nebo minstrberského vévodství. Ruku v ruce se zvýšením záběru konfirmací stoupá i jejich absolutní počet, který se v prvních deseti letech 14. století zdvojnásobil oproti př̀edchozí dekádě. Vývoj konfirmací tu v zásadě kopíruje tendence všech slezských knížecích písemností určených pro města ${ }^{117}$.

Růst počtu konfirmací pokračuje i v druhém desetiletí 14. století. Na podobné úrovni se nachází i ve třetím decéniu. V letech 1331-1340 dochází dokonce ke kvantitativnímu regresu. Od 20. let se jako jejich nejdůležitější vydavatel profiluje Boleslav III. Lehnicko-Břežský. Vedle něj v roli vydavatelů konfirmací v té době vystupují Jan Lucemburský, Boleslav II. Minstrberský a někteří další, leč role Boleslava III. je ve 20. a 30. letech klíčová.

$\mathrm{K}$ výraznému početnímu nárůstu dospívají konfirmace ve 40. letech 14 . století - z tohoto pohledu tvoří vrchol celého sledovaného období. Do těchto let se totiž koncentrovalo několik událostí, které byly vhodné k jejich emisi. Patřily sem změny v lehnicko-břežském knížectví, v jehož lehnické části se nejprve vzdal vlády Boleslav III. Marnotratný, poté zde společně vládli jeho synové Ludvík a Václav, aby si roku 1346 vládu rozdělili. Všechny tyto změny byly doprovázeny konfirmačními listinami. Druhou důležitou událostí byl nástup Karla IV. na český trůn a také na knížecí stolce ve Vratislavsku a Hlohovsku. Ale konfirmační listiny tehdy vydávala i jiná knížata, i když většina produkce směřovala do měst vratislavského, hlohovského a lehnického knížectví.

Po konfirmačních „hodech“ 40. let přichází v následujícím desetiletí útlum. Ten potom pokračuje i dále, kdy k nejnižší emisi konfirmací dochází v 60. letech,

${ }_{114}$ Historia Śląska, t. I., díl 1., red. K. Maleczyński, Wrocław 1960, s. 448; Slezsko v dějinách českého státu, t. I., red. Z. Jirásek, Praha 2012, s. 230-232; M. B o g u c k a, H. S a m s o n ow i c z, Dzieje miast, s. 105-123.

115 T. Ve 1 i č k a, Zeměpanské konfirmační listiny [disertace], s. 205.

116 Tamtéž.

117 Tamtéž, s. 232. 
ale situace se př́liš nezlepšuje ani v 70. a 80. letech. Zatímco v 50. letech většinu slezských městských konfirmací vydal Karel IV., 60. léta jsou vydavatelsky pestřejší. V 70. letech opět převládají konfirmace českého krále - ale již Václava IV. V 80. letech se počet dochovaných konfirmací ještě snižuje - tato dekáda představuje jejich nejhlubší propad. Tehdy bylo vystaveno (a dochovalo se) pouhých 6 potvrzovacích listin.

K výraznému oživení konfirmační aktivity dochází v 90. letech 14 . století. Vysvětlení nárůstu není tak jednoznačné jako ve 40. letech - nelze jej tentokrát převést na společného jmenovatele změn vlád $\mathrm{v}$ jednotlivých knížectvích. $\mathrm{K}$ těm samožrejmě docházelo, ale projevily se jen v břežském knížectví jedinou konfirmací Jindřicha IX. Břežského (pro Olavu) ${ }^{118}$. Mezi vydavateli ostatně nikdo nedominuje. Nejvíce je v 90. letech konfirmací Václava IV. a královských hejtmanů ve Svídnicko-Javorsku a Vratislavsku. Aktivní byl rovněž Ludvík I. Břežský, ale i Ruprecht Lehnický. Ani jedno z těchto knížat, ani král Václav IV. se tehdy ale nenacházeli $\mathrm{v}$ počátcích své vlády.

V prvních dvou desetiletích 15 . století počet dochovaných konfirmací opět klesá. V letech 1401-1410 byli nejpilnějšími vydavateli potvrzovacích listin Václav IV. a svídnicko-javorský hejtman Jan Krušina z Lichtenburka. Dohromady vystavili 10 ze 14 dochovaných konfirmací (Václav IV. sedm, Jan Krušina tři). Důvodem dalšího poklesu v letech 1411-1419 byla nejspís takřka úplná absence těchto vydavatelů. Václav již tehdy nevystavil žádnou konfirmaci, jeho hejtmané jen jedinou - svídnicko-javorský hejtman Jindřich z Lažan. Mezi tehdejšími vydavateli vyniká Ludvík II. Břežský a Jindřich IX. a Jindřich X. Zaháňští.

I. Zeměpanské konfirmace pro slezská města podle desetiletí



Důležité je zjištění, že čeští panovníci i hejtmané vystavovali své konfirmační listiny pouze pro městské príijemce z knížectví, které byly pod jejich přímou vládou (tedy Vratislavsko, Hlohovsko a Svídnicko-Javorsko). Výjimkou je jedině listina Karla IV., jíž potvrdil privilegium pro Krapkowice ležící v opolském knížectví.

${ }^{118}$ G. S c hu 1 z, Ohlaus Vergangenheit, Ohlau 1902, s. 170. 
Učinil tak na žádost tamního knížete Albrechta Střeleckého ${ }^{119}$. V konfirmaci byla obsažena vysoká peněžní sankce (100 hřiven zlata), nicméně obsah písemnosti, jež byla potvrzena, nebyl nijak výjimečný - šlo o poskytnutí polností s povolením zř́zení rybníka obsahující též ustanovení o př́íslušných platech.

Jak se slezský materiál jeví z hlediska vydavatelů? Na vrcholu stojí dva dlouho vládnoucí monarchové - Václav IV. a Boleslav III. Marnotratný. Přes deset konfirmací se kromě nich dostal již jen Karel IV. Skupinu konfirmačně aktivních vladařu uzavírají Anežka Svídnická, Ludvík II. Břežský a královští hejtmané. U posledně jmenovaných je potřeba se zastavit.

I pro české prostředí se dochovaly některé písemnosti podkomořího, které v určitých prrípadech suplovaly panovnické písemnosti - konfirmace se mezi nimi nacházela jen jednou, takže šlo o zcela výjimečný př́pad ${ }^{120}$. Ve Slezsku byla situace jiná. Český král zde nerezidoval a ani jeho dlouhotrvající pobyty ve Vratislavi nemohly suplovat jeho dlouhodobou př́tomnost $\mathrm{v}$ zemi ${ }^{121}$. Jeho zástupcem se ve všech Koruně podřízených knížectvích stával královský hejtman. Ve vratislavském knížectví to zpočátku býval příslušník místní šlechty, ale postupně sem byli dosazování důvěrníci krále nepocházející ze Slezska. Ve Svídnicko-Javorsku se domácí šlechta do hejtmanského úřadu již od počátku neprosazovala, i když čeští šlechtici, vykonávající tento úřad, se v knížectví často zakupovali122. Úkoly a pravomoci hejtmana se odvíjely od potřeby vyřizovat záležitosti, které příslušely panovníkovi. Zahrnovaly především potvrzování majetkových přesunů v knížectví, soudní pravomoci a udržování pořádku a obranu území. Vratislavští hejtmané byli někdy králem pověřováni zvláštními úkoly přesahujícími správu knížectví123. V některých př́ípadech je také doloženo potvrzování zeměpanských listin - nejdř́ve v této roli vystoupil vratislavský hejtman Konrád z Falkenheimu roku 1351. Častěji, a to už především svídnicko-javorští hejtmané, potvrzovali listiny knížat na sklonku 14. století. Nedá se zřetelně ohraničit skupina prŕijemců a okruh potvrzovaných skutečností, v nichž se zájemci o konfirmaci obraceli bud' k hejtmanovi, nebo k panovníkovi. Mezi hejtmanskými konfirmacemi je více potvrzení právních aktů, nicméně takové občas potvrzovali i panovníci.

119 RŚ1 III., č. 500.

120 T. Ve li č k a, Zeměpanské konfirmační listiny [disertace], s. 166-167. Listina vydána v: t e n t ý ž, Města v žateckém kraji a královští úředníci v době předhusitské, Porta Bohemica 6, 2013, s. 186-187, č. 16.

${ }^{121}$ Viz M. H o lá, Pobyty Jana Lucemburského a jeho syna Karla ve Vratislavi 13271345, v: Pierwsze polsko-czeskie forum młodych mediewistów, Poznań 2007, s. 217-232; tá ž, Pobyty Karla IV. a jeho dvora ve Vratislavi v letech 1348-1372, v: Dvory a rezidence ve středověku, Praha 2006 (Mediaevalia Historica Bohemica, suppl. 1), s. 163-189; I. H1 a vá č e k, Vratislav jako místo pobytu Karla IV. a Václava IV. (k interpretaci pozdněstředověkých panovnických itinerářů), v: Źródłoznawstwo i studia historyczne, Wrocław 1989, s. $165-174$.

${ }^{122}$ M. H o l á, Vratislavská hejtmanská kancelář, s. 47-80; J. Z e l e n k a, Vznik a fungování hejtmanské správy ve svídnickém a javorském knížectví za vlády Václava IV., v: Hejtmanská správa ve vedlejších zemích Koruny české, Opava 2009, s. 103-114, kde shrnuta starší literatura.

${ }^{123}$ M. H o lá, Vratislavská hejtmanská kancelář, s. 55-56. 
II. Vydavatelé konfirmačních listin pro slezská města

\section{počet kusů}

$\begin{array}{lll}\text { 1.-2. } & \text { Václav IV. }{ }^{124} & 18 \\ & \text { Boleslav III. }^{126} & 18 \\ \text { 3. } & \text { Karel IV. }^{128} & 13 \\ \text { 4.-6. } & \text { Anežka Svídnická }^{130} & 9 \\ & \text { Ludvík I. }^{132} & 9 \\ & \text { královští hejtmané }^{133} & 9 \\ \text { 7.-8. } & \text { Ruprecht Lehnický }^{135} & 6 \\ & \text { Bolek II. Malý137 }^{137} & 6 \\ \text { 9.-12. } & \text { Jindřich IV. Probus } & \\ & & 5\end{array}$

$\begin{array}{lll}\text { 18.-22. } & \text { Jindřich IV. Věrný }{ }^{125} & 2 \\ & \text { Bernard Svídnický } & \\ & \text { Jindřich V. Železný }^{129} & 2 \\ & \text { Václav II. Lehnický }^{131} & 2 \\ & \text { Jindřich IX. a X. Zaháňští } & 2 \\ \text { 23.-35. } & \text { Jindřich III. Hlohovský } & 1 \\ & \text { Přemysl Ratibořský }{ }^{136} & 1 \\ & \text { Konrád II. Hrbatýy } & 1 \\ & \text { Lešek Ratibořský }{ }^{130} & 1\end{array}$

počet kusů

2

2

2

2

2

23,-35. Jindrich III. Hlohovký134

$6 \quad$ Přemysl Ratibořský1 ${ }^{136} \quad 1$

$5 \quad$ Lešek Ratibořský ${ }^{140} \quad 1$

${ }^{124}$ AP Wrocław, DM Wrocławia, č. 440 (KDPAPDS V., č. 75); AP Wrocław, rep. 135c, č. 98 (Repert. d. Schweidn. Archivs, t. I), s. 35, 1; AP Wrocław, AM Świdnicy 411, f. 6r-8r; AP Wrocław, DM Wrocławia, č. 12586, 639 (KDPAPDS V., č. 647), 992, 1061; O. M e i $\mathrm{n}$ a rd u s, Das Neumarkter Rechtsbuch, č. 46, 51; AP Wrocław, AM Wrocławia, sign. D 12, s. 75; Codex Germaniae diplomaticus, t. II., sl. 121-123, č. 13; AP Wrocław, AM Jeleniej Góry, č. 41, 53, 54, tamtéž, vidimus z roku 1655; Urkunden der Stadt Löwenberg, č. 31; CDS XXXV., s. 49, č. 55.

125 SR č. $3989,4917$.

126 SR č. 2864, 3135, 3143, 3392, 3395, 3533, 3593, 4304, 4343, 4545, 4626, 4712, 4740, 4798, 6215, 6349, 6535; RŚl I., č. 208.

127 SR č. $3172,3614$.

128 SR č. 6674, 6703, 6704; BU č. 179, 190; RŚl II., č. 538, 618, III., č. 243, 344, 404, 500; SRS I., s. 909; Th. L i n d n e r, Aus dem Archive der Stadt Jauer, s. 89, č. 41; AP Wrocław, DM Świdnicy, č. 198 (KDPAPDS V., č. 470).

129 RŚl I., č. 149, II., č. 24.

130 Landbuch I., č. 396; Biblioteka Uniwersytecka we Wrocławiu, sign. R 2721, s. 45; AP Wrocław, rep. 6, pag. 1578, 161 (regest); Landbuch I., č. 74, II., č. 15; AP Wrocław, rep. 135d, č. 377 (Privilegia der Städte des Fürstentums Schweidnitz-Jauer), s. 221-222; Th. L i n d n e r, Aus dem Archive der Stadt Jauer, s. 93, č. 76; CDS XXVII., s. 180-18, č 14.

131 UBSL č. 438; AP Wrocław, rep. 132a, dep. miasta Złotoryi, č. 5 (81).

132 SR č. 6349, 6915; RŚl I., č. 15, II., č. 412; UBSL č. 140; AP Wrocław, rep. 132a, dep. miasta Chojnova, č. 45, 49; AP Wrocław, rep. 132a, Urkunden der Stadt Ohlau, č. 29; G. S c hulz, Ohlaus Vergangenheit, s. 170.

133 O. M e in a rd u s, Das Neumarkter Rechtsbuch, č. 34; AP Wrocław, AM Wrocławia, D 24, f. 59v; Urkunden der Stadt Löwenberg, č. 33; Landbuch III., č. 50, 760, 1647, 1687; AP Wrocław, rep. 132a, dep. miasta Dzierżoniowa, č. 45.

134 SUb VI., č. 428.

135 AP Wrocław, rep. 132a, dep. miasta Złotoryi, č. 53, 69, 76; UBSL č. 313; AP Wrocław, rep. 132a, dep. miasta Chojnowa, č. 50; Cod. Univ. Lips. 1527, 098, Diplomata principatuum Silesiae inedita (citováno dle kartotéky na katedře historie Vratislavské univerzity, č. 13317; samotný odkaz jsem nebyl schopen ověřit).

136 SR č. 2862.

137 SR č. 4751, 5882, 6694; RŚl I., č. 660, II., č. 11; AP Wrocław, DM Świdnicy, č. 119 (reg.: KDPAPDS IV., č. 544).

138 SR č. 2804.

139 SUb IV., č. 282, 284, 300, 307, V., č. 66.

140 SR č. 3013. 


\begin{tabular}{|c|c|c|c|}
\hline & Jindřich V. Tlustý141 & 5 & Heřman Braniborský ${ }^{142}$ \\
\hline & Jan Lucemburský ${ }^{143}$ & 5 & Kazimír Těšínský ${ }^{144}$ \\
\hline & Václav I. Lehnický ${ }^{145}$ & 5 & Konrád I. Olešnický146 \\
\hline \multirow[t]{3}{*}{ 13.-15. } & Jindřich VI. Dobrý' ${ }^{147}$ & 4 & Jan Jindřich ${ }^{148}$ \\
\hline & Jindřich I. Javorský' ${ }^{149}$ & 4 & Přemek Těšínský150 \\
\hline & Ludvík II. Břežský151 & 4 & Konrád II. Olešnický152 \\
\hline \multirow[t]{3}{*}{ 16.-17. } & Boleslav II. Minstrberský ${ }^{153}$ & 3 & Jindřich IX. Břežský ${ }^{154}$ \\
\hline & Jan Stínavský155 & 3 & Jan I. Zaháňský156 \\
\hline & & & Bolek Těšínský ${ }^{157}$ \\
\hline
\end{tabular}

Otázka konfirmačních listin jako iniciačního aktu mezi zeměpánem a městem zaslouží rovněž svůj prostor. Přirozeně, že tu lze hovořit jen o období do roku 1360, do kdy je k dispozici kompletně zpřístupněná materie. Do následujícího srovnání byli vybráni nejvýznamnější vydavatelé konfirmací z této doby ${ }^{158}$. Vyplývá z něj, že situace nebyla jednotná. U českých králů Jana Lucemburského a Karla IV. bývala vesměs konfirmace i první listinou pro konkrétního prř́jemce. Naopak pro vládce lehnicko-břežského knížectví to spíše neplatilo, stejně jako pro Bolka II. Svídnického. Podobné trendy v zásadě pozorujeme i po roce 1360. Například v Lehnici nebyla konfirmace první listinou ani v prrípadě Ruprechta, zatímco u Václava II. v roce 1409 tomu tak bylo, naopak u Ludvíka II. zase nikoliv. Platí to i pro jeho konfirmace určenou městu Břeh. První listinným kontaktem mladého Václava IV. s Vratislaví byla jeho konfirmace z roku 1367.

Pokud jde o jednotlivé př́ijemce a množství konfirmačních listin, které se pro ně dochovalo, pak jednoznačně vévodí Vratislav. Následována je Lehnicí, Břehem a Svídnicí. Tedy velmi podobné pořadí, jaké bylo zjištěno pro kompletní materii pro tyto př́jemce do roku $1360^{159}$. Pokud rozdělíme prřijemce do př́islušných knížectví, pak vystupují do popředí tři: svídnicko-javorské, lehnicko-břežské a vratislavské.

141 SUb V., č. 461, 467, VI., č. 46, 83, 140.

142 SR č. 2960.

143 SR č. 4638, 5051; BU, č. 172, 177; RŚl I., č. 258.

144 SR č. 3563.

145 SR č. 6915; RŚl I., č. 15, 505, 726, II., č. 835.

146 SR č. 3900.

147 SR č. 3135, 3143, 3234, 3241.

148 BU č. 179.

149 SR č. 3172 , 3906, 4259; RŚl I., č. 243.

150 SRS I., s. 730.

151 CDS IX., č. 681; K. F. S c h ö n w ä ld e r, Geschichtliche Ortsnachrichten von Brieg, díl 1, Breslau 1846, s. 226; UBSL č. 475; AP Wrocław, rep. 132a, dep. miasta Złotoryi, č. 7.

152 AP Wrocław, rep. 4 b, č. 8 (3).

153 SR č. 3172, 5290, 5467.

154 AP Wrocław, rep. 135c, č. 73 (archiwalia Oławy), č. 38.

155 SR č. 4138, 5142; RŚl I., č. 709.

156 CDS XXVIII., s. 44, č. 171.

157 RDPGŚ II., č. 200.

158 Tedy období do roku 1360.

159 T. Ve li č k a, Zeměpanské konfirmační listiny [disertace], s. 233-235. 
V první jedenáctce se nacházejí tři zástupci Lehnicko-Břežska, pět měst ležících ve Svídnicko-Javorsku plus Vratislav. Mimo tato knížectví stál v rámci předních prríček (prvních 11 prŕjemců) jen Hlohov a Frankenštejn. Na prvních jedenácti pozicích tak vedou $\mathrm{v}$ počtu dochovaných konfirmací prŕjjemci ze svídnicko-javorského knížectví1 ${ }^{160}$ následováni městy lehnického knížectví161 a po nich zástupci vratislavského knížectví (resp. jen Vratislaví) ${ }^{162}$.

III. Slezská města podle počtu přijatých konfirmací

$\begin{array}{llcllc} & & \text { počet kusů } & & \text { počet kusů } \\ \text { 1. } & \text { Vratislav }^{163} & 27 & \mathbf{1 8 . - 2 3} . & \text { Grodkov }^{164} & 2 \\ \text { 2. } & \text { Lehnice }^{165} & 13 & & \text { Těšín }^{166} & 2 \\ \text { 3.-4. } & \text { Břeh }^{167} & 12 & & \text { Ratibor̆168 }^{168} & 2 \\ & \text { Svídnice }^{169} & 12 & & \text { Namyslov }^{170} & 2 \\ \text { 5. } & \text { Goldberk }^{171} & 9 & & \text { Krosno }^{172} & 2 \\ \text { 6. } & \text { Lemberk }^{173} & 8 & & \text { Landshut }^{174} & 2 \\ \text { 7.-8. } & \text { Javor }^{175} & 7 & \mathbf{2 4 .} & \text { Boleslavec }^{176} & 2 \\ & \text { Hlohov }^{177} & 7 & \mathbf{2 5 . - 3 4 .} & \text { Ryczeńn }^{178} & 1\end{array}$

${ }^{160}$ Svídnice, Lemberk, Javor, Hiršberk a Střehom = 37 kusů.

161 Lehnice, Břeh, Goldberk = 34 kusů.

162 A dále Frankenštejnsko (Frankenštejn) a Hlohovsko (Hlohov).

163 SUb IV., č. 282, 307, V., č. 66, 461, 467; SR č. 2864, 3135, 3143, 3234, 3241, 4638, 6674; RŚl I., č. 34, 117, 241, 713, II., č. 618, III., č. 310, 404; AP Wrocław, DM Wrocławia, č. 440, 12586, 639, 992, 1046, 1167; AP Wrocław, AM Wrocławia, D 12, s. 75; D 24, f. 59v (regest).

164 SUb IV., č. 284; SR č. 4304.

165 SR č. 3392, 3533, 3593, 4740, 6215, 6915; UBSL č. 140, 313, 438, 475; RŚl I., č. 505, II., č. 412, III., č. 835.

166 SRS I., s. 730; RDPGŚ II., č. 200.

167 SUb VI., č. 46, 83, 140; SR č. 3395, 4304, 4545, 4712, 4798, 6349; RŚl I., č. 208; CDS

IX., č. 681; K. F. S c h ö n w äld e r, Geschichtliche Ortsnachrichten von Brieg, díl 1., s. 226.

168 SR č. 2862, 3013.

169 SUb IV., č. 300; SR č. 3172, 3614, 4751; RŚ1 I., č. 660; AP Wrocław, DM Świdnicy, č. 119; AP Wrocław, rep. 135c, č. 98 (Repert. d. Schweidn. Archivs, t. I), s. 35, 1; Biblioteka Uniwersytecka we Wrocławiu, sign. R 2721, s. 45; AP Wrocław, DM Świdnicy, č. 198, 258; AP Wrocław, rep. 6, pag. 1578, 161 (regest); Landbuch I., č. 74.

170 RŚl III., č. 243; Codex Germaniae diplomaticus, t. II., sl. 121-123, č. 13.

171 SR č.4626, 6535; RŚl I., č. 15, 726; AP Wrocław, rep. 132a, depozyt miasta Złotoryi, č. $53,69,76,5$ (81), 7 (83).

172 SR č. 4917; Cod. Univ. Lips. 1527, 098 (jako pozn. 135).

173 SR č. 3906, 4259; Landbuch I., č. 396, III., č. 1647; AP Wrocław, DM Świdnicy, č. 258; Urkunden der Stadt Löwenberg, č. 30, 31, 33.

174 SR č. 6694; AP Wrocław, DM Świdnicy, č. 258.

175 RŚl I., č. 243, II., č. 11; Th. L i n d n e r, Aus dem Staatsarchiv von Jauer, s. 89, č. 41, s. 93, č. 76; AP Wrocław, DM Świdnicy, č. 258; CDS XXXV., č. 55; Landbuch III., č. 1687.

176 AP Wrocław, DM Świdnicy, č. 258; Landbuch III., č. 760.

177 SR č. 3989, 5051, 6703, 6704; RŚl I., č. 149, II., č. 24; CDS XXVIII., s. 44, č. 171.

178 AP Wrocław, rep. 4 b, č. 8 (3). 


\begin{tabular}{|c|c|c|c|}
\hline 9. & Frankenštejn ${ }^{179}$ & 6 & Kožuchov ${ }^{180}$ \\
\hline \multirow[t]{2}{*}{$10 .-11}$. & Hiršberk $^{181}$ & 5 & Stř̌elín ${ }^{182}$ \\
\hline & Střehom $^{183}$ & 5 & Świebodzice ${ }^{184}$ \\
\hline \multirow[t]{6}{*}{ 12.-17. } & Olava $^{185}$ & 3 & Šprotava $^{186}$ \\
\hline & Góra ${ }^{187}$ & 3 & Bělá188 \\
\hline & Stř̌eda ${ }^{189}$ & 3 & Lubín $^{190}$ \\
\hline & Reichenbach $^{191}$ & 3 & Stínava $^{192}$ \\
\hline & Chojnov $^{193}$ & 3 & Krapkovice ${ }^{194}$ \\
\hline & Bierutov $^{195}$ & 3 & Gryfów ${ }^{196}$ \\
\hline
\end{tabular}

Porovnáme-li tyto údaje s odhadovanou velikostí jednotlivých měst pro polovinu 14. století, pak je čelo žebříčku velmi podobné. Vratislav, Lehnice, Břeh i Svídnice patřily i z tohoto pohledu k nejvýznamnějším ${ }^{197}$.

Nezajímavé není ani srovnání celkového počtu přijatých písemností a konfirmací (obojí do roku 1360). Z měst na předních příčkách v počtu dochovaných zeměpanských kusů neměla žádnou konfirmaci Střehom a Chojnov. Málo byly s ohledem na množství všech přijatých kusů zastoupeny konfirmace ve Svídnici. Větší podíl vzhledem k ostatní materii tvořily konfirmace především u Břehu, kde to byla jedna

179 SR č. 2960, 5290, 5467; RŚl II., č. 538, III., č. 344; Biblioteka Uniwersytecka we Wrocławiu, sign. R 2721, s. 45.

${ }^{180}$ CDS XXIV., s. 3, č. 3.

181 AP Wrocław, DM Świdnicy, č. 258; AP Wrocław, DM Jeleniej Góry, č. 41, 53, 54; Landbuch III., č. 1687.

182 RŚl I., č. 258.

183 AP Wrocław, rep. 6, s. 1578, 161 (dva různé záznamy); AP Wrocław, DM Świdnicy, č. 258; Landbuch II., č. 15, III., č. 50 .

184 SR č. 5882.

185 AP Wrocław, rep. 132a (Urkunden der Stadt Ohlau), č. 29 (dle inventáře, originál není); G. S c h u l z, Ohlaus Vergangenheit, s. 170; AP Wrocław, rep. 135c, č. 73 (archiwalia Oławy), č. 3.

186 SR č. 2804.

187 SR č. 4138; AP Wrocław, rep. 4b, č. 8 (3); B. Z i o ł e c k i, Geschichte der Stadt Guhrau, Guhrau 1900, s. 40 (jen zmínka v dějinách města).

188 SR č. 3563.

189 O. M e in a rd u s, Das Neumarkter Rechtsbuch, č. 34, 46, 51.

190 SR č. 5142.

191 AP Wrocław, rep. 135d, č. 377 (Privilegia der Städte des Fürstentums Schweidnitz-Jauer), s. 221-222.; AP Wrocław, DM Świdnicy, č. 258; AP Wrocław, rep. 132a, dep. miasta Dzierżoniowa, č. 45.

192 RŚl I., č. 709.

193 AP Wrocław, rep. 132a, dep. miasta Chojnova, č. 45, 49 (podle předválečného archivního inventáře, originály se nezachovaly), 50.

194 RŚl III., č. 500.

195 SUb VI., č. 428; SR č. 3900, 4343.

196 AP Wrocław, AM Jeleniej Góry, vidimus z roku 1655.

197 Historia Śląska, t. I/1, s. 249: Vratislav (13-15 tis.), Lehnice, Lemberk (9-11,5 tis.), Hlohov (9-10 tis.), Svídnice (8-9,5 tis.), Minstrberk, Reichenbach, Nisa (ca 5 tis.), Středa, Břeh (4,5-5 tis.), Ratiboř (ca 3 tis.), Opole (ca 2,5 tis.) atd. 
čtvrtina. O něco vyšší zastoupení představovaly konfirmace pro Hlohov - tady to byla pětina až šestina celkového úhrnu všech zeměpanských písemností. Zhruba tolik to bylo i v prrípadě Vratislavi.

IV. Podíl konfirmací na úhrnu všech přijatých zeměpanských písemností u měst s nejvy̌̌ším počtem zeměpanských kusů (do roku 1360)

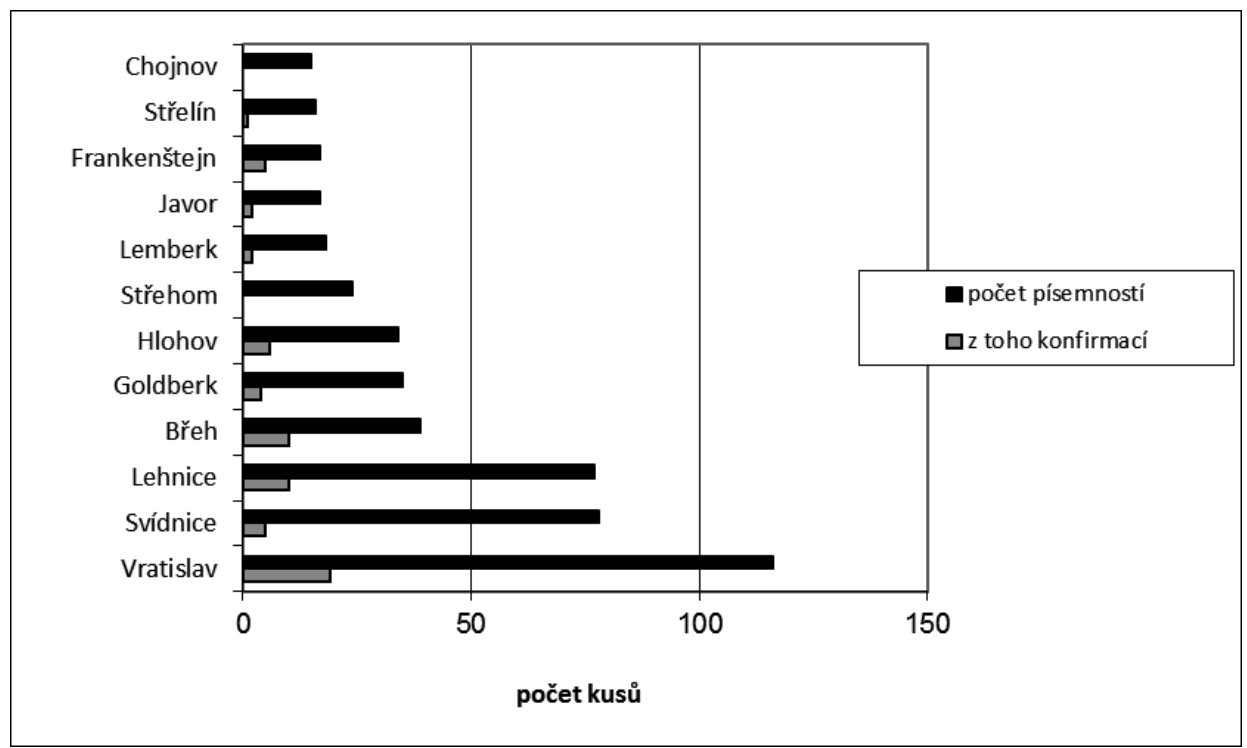

2. Formulář konfirmačních listin

Celkem se dochovalo na 144 konfirmačních listin pro zkoumané př́jemce. Ovšem jen malá část $\mathrm{z}$ nich je $\mathrm{k}$ dispozici $\mathrm{v}$ plnotextovém původním znění: pouze 81 kusů. Slezský prostor byl rozčleněn na mnoho samostatných knížectví, mezi vydavateli konfirmačních listin se nachází poměrně značné množství osob. Proto je třeba postupovat následujícím způsobem, a to hned z trojí perspektivy. Kromě pohledu po vydavatelské a př́ijemecké linii bude nutné zohlednit též hledisko chronologické ve smyslu utváření formuláře konfirmačních listin od 13. až do počátku 15. století.

Nejlepší podmínky pro následující rozbor poskytují písemnosti Boleslava III. Lehnicko-Břežského ${ }^{198}$ a Václava IV. ${ }^{199}$, kde přichází v úvahu 15, resp. 14 kusů. Více

198 BU č. 76, 88, 89; UBSL č. 38; CDS IX., č. 11, 21, 26, 30; AP Wrocław, AM Legnicy II., č. 1201 (kopiář Ambrože Bitschena), f. 65rv; UBSL č. 49, 85, 144; USUS s. 125, 129; A. S c h a u b e, Urkundliche Geschichte, č. 31.

199 AP Wrocław, DM Wrocławia, č. 440, 639 (KDPAPDS V., č. 75, 647), 1004, 1061, 1186; AP Wrocław, AM Świdnicy 411, f. 6r-8r; O. M e in a rd u s, Das Neumarkter Rechtsbuch, č. 46, 51; Codex Germaniae diplomaticus, t. II., sl. 121-123; AP Wrocław, AM Jeleniej Góry, č. 41, 53, 54, tamtéž, vidimus z r. 1655; Urkunden der Stadt Löwenberg, č. 31. 
než pět dnes plnotextově dochovaných konfirmačních listin měl na svém „kontě“ již jen Karel IV. (6 kusů $)^{200}$.

a) podle vydavatelů

Nicméně sledovaný formulář konfirmačních listin by neměl ztrácet ze zřetele zařazení do kontextu ostatních písemností týchž vydavatelů. Pro většinu z nich ale nedisponujeme př́íslušnými zpracováními, o něž bychom se mohli opírat. Z tohoto důvodu si tak v přehledu vývoje formuláře konfirmací všimneme jen čtyř vydavatelů, kde situace umožňuje širší srovnání. Půjde jednak o dvě knížata končícího 13. století (Jindřicha IV. Vratislavského a Jindřicha V. Tlustého), jednak o české krále Karla IV. a Václava IV.

Pro analýzu slohu konfirmací Jindřicha IV. Vratislavského tu můžeme použít pět kusů ${ }^{201}$. Přrislušné listiny začínají ve všech případech invokací. Čtyřikrát zní In nomine domini amen, jedenkrát In nomine dei eterni amen, kterou začíná konfirmace pro Vratislav z roku $1282^{202}$. Tato druhá invokace je skutečně výjimečná, nebot' v ostatních Jindřichových přichází již jen jedinkrát, zatímco první varianta je doložena nepoměrně častěji. S invokací In domine dei eterni amen se lze podruhé setkat v konfirmační listině vydané pro vratislavský klášter kř́žžovníků s červenou hvězdou ve stejném roce jako vratislavská konfirmace ${ }^{203}$. Winfried Irgang tuto variantu invokace vztahuje k vlivu prŕjemce ${ }^{204}$.

Intitulace se ničím neliší od jejich použití v ostatních Jindřichových listinách. Totéž platí i pro ostatní části protokolu.

Arengy přichází ve všech pěti zkoumaných kusech. Zpravidla šlo o arengy, které se vyskytly i v jiných jeho listinách. Nejlépe to dokládá ta, která byla užita v privilegiu pro Vratislav roku $1277^{205}$. Našli bychom ji ještě v dalších třech jeho písemnostech ${ }^{206}$.

U dvou nejstarších Jindřichových konfirmací pro městské př́ijemce se jedná o kvasikonfirmace, takže v jejich dispozicích nenajdeme žádná konfirmační slovesa. Jejich diktát činí dojem, jako by udělovaly něco nového, ale přesto udělují něco již uděleného. U dalších potvrzovacích listin již konfirmační formulář nacházíme. Stejně jako v Čechách té doby je poměrně stručný, ale přesto je bohatší než v soudobých panovnických konfirmacích v českém království. V konfirmacích pro Svídnici a Vratislav z let 1276-1277 není ještě tak široký, rozšiřuje se však v privilegiu pro Vratislav uděleném roku 1283, kdy již před první inserovanou a potvrzovanou

200 BU č. 168, 179, 190, 204; SRS I., s. 909-10; AP Wrocław, DM Świdnicy, č. 198 (KDPAPDS V., č. 470).

201 SUb IV., č. 282, 284, 300, 307, V., č. 66.

202 SUb V., č. 66.

203 SUb V., č. 75; W. I r g a n g, Das Urkunden- und Kanzleiwesen Herzog Heinrichs IV., s. 436.

${ }^{204}$ Tamtéž. Pokud jde o četnost invokací, zkoumané listiny v tomto ohledu nebyly žádnými výjimkami, nebot' z Jindřichových 123 plnotextově dochovaných listin jí nedisponovalo jen 21 (tamtéž).

205 SUb IV., č. 307: Ea, que ex principum beneplacito ad subditorum commoda conceduntur, aliquociens sibi renovacionis remedio indigent subveniri, ut ea, que vetera sunt, wltum novitatis assumendo pociorem adhibicionem fidei conquirant et maioris gaudeant fulcimine firmitatis.

206 W. I rg a n g, Das Urkunden- und Kanzleiwesen Herzog Heinrichs IV., č. 436. 
listinou zaznívá triplikované potvrzení ratificamus, approbamus et--confirmamus, a za ní je ještě zopakováno confirmamus. Za insertem druhé listiny pak stojí ještě observační formule - omnia - - salvo volumus conservari ${ }^{207}$.

Sankce se běžně v Jindřichových konfirmací nevyskytovala, narážíme na ní jen jedinkrát, v privilegiu pro Grodkov z roku 1276, kdy má formu mandátu úředníků (tedy mandační sankce) $)^{208}$.

Pokud jde o formuláŕ eschatokolu, povšimněme si nejdř́ve svědečných řad. Ta byla ve všech př́padech součástí listinného formuláře. To ostatně souzní s charakterem Jindřichových písemností jako celkem, kde chybí jen asi v 6\% př́ípadů ${ }^{209}$.

Datace je uvozena Actum popř. Acta. Za ní následuje místo vydání, poté rok vydání, denní datum - vždy podle římského kalendáře - a $\mathrm{v}$ jednom případě je na závěr uvedena indikce ${ }^{210}$. Její uvedení bylo $\mathrm{v}$ Jindřichově kanceláři velkou zvláštností, nebot' kromě zmíněného případu přichází již jen jedinkrát ${ }^{211} \mathrm{v}$ listině určené pro vratislavské křížovníky s červenou hvězdou, jež byla vydána jen několik dní po výše uvedené vratislavské konfirmaci ${ }^{212}$. Listiny Jindřicha Proba znaly kromě římského kalendáře také datování podle křest’anských svátkưํำ

Dpm formule byla pevnou součástí Jindřichových listin a málokdy chybíi ${ }^{214}$. Má podobu Datum per manus, nebo per manum ${ }^{215}$ a ve sledovaných konfirmacích nechybí ani jednou. Čtyřikrát je v ní uvedenen notář Jindřich ${ }^{216}$, kanovník vratislavské katedrální kapituly, který v kanceláří pracoval v letech 1273-1277²17. Během svého poměrně krátkého působení se objevuje hned ve 20 knížecích listinách jako datářr218. Kromě notáře Jindřicha se jednou objevuje notáŕ Ludvík ${ }^{219}$.

Existuje vzájemná podobnost formuláře u některých z pojednaných konfirmací? U dvou tomu tak je. Podobají se konfirmace pro Grodkov a Svídnici z roku ${ }^{220}$. Obě jsou to navíc kvasikonfirmace a mají stejnou arengu, koroboraci, úvod subskripce a formu dpm formule jako per manum.

U Jindřicha $V$. se plnotextově dochovalo pět potvrzovacích listin ${ }^{221}$. Dvě z jeho konfirmací začínají invokací, která zní In nomine domini amen. Ve třech nefiguruje, což je ale jinak v Jindřichově kanceláři dost výjimečné, nebot' z celého jeho diplomatického působení jsou známy jen čtyři listiny nemající invokaci ${ }^{222}$.

207 SUb V., č. 66.

208 SUb IV., č. 284.

${ }^{209}$ W. Irg a n g, Das Urkunden- und Kanzleiwesen Herzog Heinrichs IV., s. 437.

210 SUb IV., č. 307.

211 W. I rg a n g, Das Urkunden- und Kanzleiwesen Herzog Heinrichs IV., s. 438.

212 SUb IV., č. 310.

${ }^{213}$ W. Ir g a n g, Das Urkunden- und Kanzleiwesen Herzog Heinrichs IV., s. 438.

${ }^{214}$ V 21\% písemností, což je sice velké množství, ale většina případů spadá do počátků jeho vlády, nebo se jednalo o př́jemecká vyhotovení. Viz tamtéž, s. 437.

215 SUb IV., č. 284, 300.

${ }^{216}$ SUb IV., 282, 284, 300, 307.

217 W. Ir g a n g, Das Urkunden- und Kanzleiwesen Herzog Heinrichs IV., s. 406-407.

218 Tamtéž, s. 408.

219 SUb V., č. 66.

220 SUb IV., č. 284, 300.

${ }^{221}$ SUb V., č. 461, 467, VI., č. 46, 83, 140.

222 A. Wałk ó w s k i, Dokumenty i kancelaria, s. 18-19. 
Intitulace začíná náslovným nos/wir, tak jako ve všech ostatních Jindřichových známých listinách ${ }^{223}$.

Na rozdíl od Jindřicha IV. Proba užíval Jindřich V. ve svých konfirmacích daleko méně arengy - z pěti kusů ji obsahuje jen jediná224, a to hned první jím vydaná pro město Vratislav roku 1290. Řadí se k velmi krátkým arengám a svým obsahem Humana gesta simul transeunt cum tempore, nisi scripturis et testibus perhennentur náleží mezi typ memoria-oblivio. V ostatních Jindřichových listinách se již nezopakovala $^{225}$. Řídké užití areng ale neplatí pro Jindřichovy listiny jako celek, kde jí většina obsahuje $\mathrm{e}^{226}$.

Velmi rozvinutým konfirmačním formulářem v dispozici disponuje konfirmace pro Vratislav z roku $1290^{227}$, kde nacházíme tři konfirmační slovesa: innovamus, ratificamus et inviolabiliter prestito iuramento perpetue confirmamus. V potvrzovacích listinách pro vratislavské Nové město ${ }^{228}$, a dvou pro Břeh z let 1292 a $1294^{229}$ se nachází jen jediné konfirmační sloveso: confirmamus. Naproti tomu v druhé břežské konfirmaci z roku $1292^{230}$ je to obrat bestetigen wir und bevestin.

Naposledy zmíněná bř̌žská konfirmace dochovaná jen v německém překladu má dosti neobvyklý formulář - kromě nezvyklého pořadí listinných formulí je to absence koroborace. Ostatní zkoumané Jindřichovy konfirmace ji mají. Ve všech čtyřech zbylých př́ípadech je však jiná. Ani v jedné z koroborací není blíže specifikována pečet' užitá k ověření písemnosti. Úplně stejná roztříštěnost koroborací a jejich variant panuje i v ostatních Jindřichových listinách, kdy jen jediná se třikrát opakuje ${ }^{231}$.

Čtyřri z pěti Jindřichových konfirmací disponují svědečnou řadou. Dvakrát je uvedena prostým slovem presentibus ${ }^{232}$, dvakrát presentibus nostris fidelibus ${ }^{233}$. Nemá ji jen atypická potvrzovací listina pro Břeh z roku $1292^{234}$. První způsob uvedení počátku subskripce je vůbec nejčastější ve všech písemnostech Jindřicha V., druhý způsob patř́ mezi méně frekventované - mimo zmíněné konfirmace se vyskytuje již jen jednou ${ }^{235}$.

Datace se nijak neliší od jejich podoby v ostatním Jindřichově diplomatickém materiálu.

Ve třech jeho konfirmacích se vyskytuje konskripční formule, spřízněná s výše pojednávanou dpm formulí. Ve dvou stojí až na úplném konci ${ }^{236}$, jednou je do ní

\footnotetext{
223 Tamtéž, s. 19.

224 SUb V., č. 461.

225 A. Wałk ó w s k i, Dokumenty i kancelaria, s. 20-22.

226 Tamtéž, s. 20.

227 SUb V., č. 461.

$228 \mathrm{SUb}$ V., č. 467.

229 SUb VI., č. 46, 110.

230 SUb VI., č. 83.

231 A. Wałkó w s k i, Dokumenty i kancelaria, s. 23.

232 SUb V., č. 461, VI., č. 46.

233 SUb V., č. 467, VI., č. 140.

234 SUb VI., č. 83.

235 A. W ałk ó w s k i, Dokumenty i kancelaria, s. 25.

236 SUb V., č. 467, VI., č. 46.
} 
vložena datace ${ }^{237}$. Dvakrát se v této formuli objevuje samotný Frycek z Jarošova ${ }^{238}$, protonotář Jindřichovy knížecí kanceláře, který v ní byl činný téměř po celou dobu její existence ${ }^{239}$. Jednou vystupuje spolu Ludvíkem, protonotářem, který do jeho kanceláře př̌šel ze služeb Jindřicha IV. Vratislavského po jeho skonu ${ }^{240}$.

Pokud bychom hledali vzájemnou podobnost potvrzovacích listin tohoto panovníka, musíme konstatovat, že není prakticky žádná. Některé Jindřichovy konfirmace však prokazují některé méně typické znaky v kontextu jeho listinných produktů - je to především častá absence invokace a arengy. Co bylo důvodem těchto odchylek, nelze jednoznačně rríci, protože jiné části formuláře již zapadají do úzu Jindřichovy kanceláře a stejně se neprojevují nijak specificky s ohledem na své diktátory.

$\mathrm{Z}$ činnosti kanceláře Karla IV. se dochovalo šest $\mathrm{v}$ úplnosti dochovaných konfirmací pro slezské městské př́ijemce ${ }^{241}$.

Třri ze šesti Karlových konfirmací začínají invokací. V případě vratislavské listiny roku 1341 a 1346 zní In nomine domini amen ${ }^{242}$, vratislavská konfirmace z roku 1356 začíná In nomine sancte et individue Trinitatis feliciter amen $^{243}$. To přesně odpovídá úzu v Karlově kanceláři a změně invokace po císařské korunovaci ${ }^{244}$. Př́ítomnost invokace byla vyhrazena Karlovým slavnostním listinám ${ }^{245}$.

Karlova intitulace se odvijí od toho, zda př́íslušnou listinu vydal před nástupem na český a římský trůn, nebo po něm. Podobným mezníkem byla císařská korunovace roku 1355 Třikrát je započata zájmenem Nos - jde bud' o konfirmace vydané ještě před ziskem královské důstojnosti ${ }^{246}$, nebo psané německy ${ }^{247}$, tak jak je běžné i v jiných jeho listinách ${ }^{248}$.

Arenga se vyskytuje ve dvou Karlových potvrzovacích listinách - pro Vratislav $\mathrm{z}$ let 1352 a $1356^{249}$. V obou př́ípadech zní shodně $-\mathrm{s}$ touto arengou jsme se jinde ve studovaném materiálu nesetkali. Je v ní tematizován vztah královského majestátu $\mathrm{k}$ poddaným. Za pozornost stojí část hovořící o věrných službách v království a koruně - pokud jde o konfirmační listiny, tak se v arengách s Korunou království

${ }^{237}$ SUb VI., č. 140.

${ }^{238}$ SUb VI., č. 46, 140.

239 A. Wałk ó w s ki, Dokumenty i kancelaria, s. 133.

${ }^{240}$ SUb V., č. 467.

${ }^{241}$ BU č. 168, 179, 190, 204; SRS I., s. 909-910; AP Wrocław, AM Świdnicy 411, f. 3v-6r.

${ }^{242}$ BU č. $168,190$.

243 SRS I., s. 909-910.

${ }^{244}$ F. T a d r a, Kanceláře a písaři v zemích českých za králů z rodu lucemburského Jana, Karla IV. a Václava IV., Praha 1892, s. 57.

${ }^{245}$ Th. L in d n e r, Das Urkundenwesen Karls IV. und seiner Nachfolger (1346-1437), Stuttgart 1882, s. 80.

${ }^{246}$ BU č. 168, 179.

247 AP Wrocław, AM Świdnicy 411, f. 3v-6r.

${ }^{248}$ F. Ta d r a, Kanceláře, s. 57.

249 BU č. 204; SRS I., s. 909-910: Quamvis innata cordi nostro benignitas ad universorum fidelium, quos nostre potestatis dicio circumquaque complectitur, utilitates et commoda procuranda piis et graciosiis inclinetur favoribus, ad illorum tamen profectus quadam singulari clemencia specialius dignamur intendere, qui ad nostre maiestatis honorem flagrantioribus votis aspirant, quosque in regni et corone serviciis fidei promptitudine et mentis immota constantia invenimus continuo puriores. 
českého setkáváme poprvé. Myšlenky této arengy pochopitelně nejsou nijak originální a nacházíme je v mnohých jiných, i Karlových, listinách, ale právě termín corona, užitý v naznačeném termínu, tuto arengu odlišuje od jiných.

Pokud jde o promulgaci, máme v každém ze studovaných kusů co dočinění s jiným typem. Přichází tu jak v českých konfirmacích nejužívanější varianta notum facimus universis ${ }^{250}$, stejně jako druhý nejrozšířenější typ ad perpetuam rei memoriam ${ }^{251}$. Máme tu i promulgaci ad universorum ${ }^{252}$. Jednou přichází recognoscimus tenore presencium universis ${ }^{253}$, která se sice $\mathrm{v}$ zkoumaném materiálu pro Čechy nevyskytla, za to se ale běžně užívala v některých slezských konfirmacích jiných vydavatelů. V německy psané konfirmaci pro Svídnici z roku 1374 se ozývá velmi častý typ bekennen und tun kunt uffinlich mit desem brive allen, der die en sehen adir horen lessen ${ }^{254}$.

$\mathrm{V}$ naraci vratislavské konfirmace z roku $1346^{255}$ zaznívá vydavatelova touha jít v otcovských šlépějích: paternis vestigiis inherere firmiter cupientes. Objevuje se tu také z českých listin známý obrat animo deliberato et maturo - - consilio ${ }^{256}$, který se v českém prostředí uchytil velmi výrazně za vlády Václava IV.

Konfirmační formulář v dispozici je v Karlových potvrzovacích listinách vesměs podobně pestrý jako pro české př́jemce. Setkáváme se tu se slovesy approbare, ratificare, confirmare, ale také ratas et gratas habentes či gratificare. Nesjtručnějši je z tohoto hlediska Karlova německá konfirmace pro Svídnici, která obsahuje jen bestetigen ${ }^{257}$. Naopak se nesetkáváme s obratem presentis scripti patrocinio, ačkoliv na něj několikrát narážíme v konfirmacích jiných vydavatelů, včetně Jana Lucemburského ${ }^{258}$. Naposledy se v některé konfirmační listině ve Slezsku vyskytl roku $1353^{259}$, pak zcela mizí, zatímco v českém prostředí se ještě občas objevuje i za Václava IV.

Sankce našla své místo ve dvou úzce spř́zzěných kusech - v konfirmacích pro Vratislav z let 1352 a $1356^{260}$. Svým utvářením se sankce neliší od sankcí užívaných Karlem pro české př́ijemce konfirmací. Co je tu však jiné, je velmi precizní určení a pojmenování vydané listiny jako approbatio, ratificatio, confirmatio, ale také promissio, sponsio, annullatio a cassatio - všech těchto sedm jmen vystihuje obsah dispozice a to, čím vším daná listina může být. Obsahuje totiž jak potvrzení, tak příslib a slib a v neposlední řadě i zneplatnění, o němž hovoříme na jiném místě.

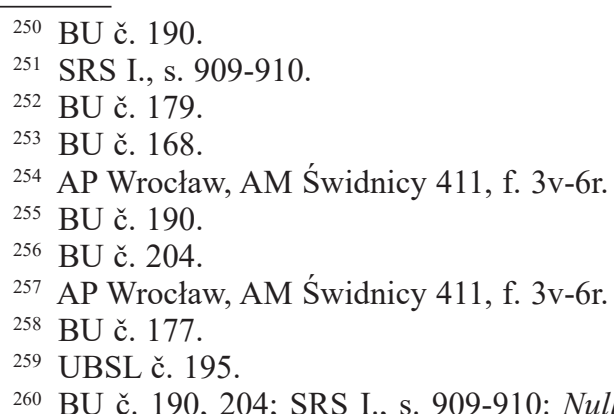
approbationis, ratificationis, confirmationis, promissionis, sponsionis, annullationis et cassationis paginam infringere aut ei quovis ausu temerario contraire sub pena nostre indignationis, quam, qui secus presumpserint, se cognoscant graciter incurisse. 
Koroborace se nejčastěji objevuje v podobě Presencium sub nostre maiestatis typario (sigillo testimonio) literarum/ bulla aurea typaria nostre imperialis majestatis impressa testimonio literarum ${ }^{261}$. Je to nejběžnější koroborace i v jeho českých konfirmacích a rovněž v ostatních listinách ${ }^{262}$. Pečetění císařskou bulou se pro sledované české př́ijemce nevyskytuje, takže ani posledně zmíněný případ v Čechách nemůže přicházet.

Dvakrát byla součástí konfirmace koroborace Harum nostrarum testimonio litterarum, (quibus nostrum maius sigillum duximus appendendum) ${ }^{263}$, která v Karlových potvrzovacích listinách v Čechách nebyla moc častá. Koroborace německé konfirmace také zůstává v mezích běžně užívaných formulí ${ }^{264}$.

Svědečná řada se objevuje jen jedinkrát a to na zvláště slavnostně vypravené konfirmaci pro Vratislav z roku $1356^{265}$. Ta byla obecně vyhrazena jen Karlovým nejslavnostnějším latinským listinám ${ }^{266}$.

Datace je zcela v souladu s územ Karlovy kanceláře ${ }^{267}$.

Relačně konceptní poznámka přichází jednou - na konfirmaci pro Vratislav z roku 1352, která byla zlistiněna na rozkaz krále Janem ze Středy ${ }^{268}$.

Vzájemnou podobnost vykazují dvě konfirmace pro Vratislav z roku 1352 a $1356^{269}$. Byla o tom řeč již výše: shodují se arengy, promulgace a především ustanovení poměrně dlouhé dispozice: Neliší se ani sankce, druhý kus má navíc subskripci a císařským monogramem a je ověřen zlatou pečetí.

U konfirmací Václava IV. je k dispozici poměrně široká srovnávací báze 14 písemností270. Při jejich hodnocení budeme muset brát zřetel na jejich jazykovou formu, nebot' tři byly psány latinsky a zbylých jedenáct německy.

Stejně jako v ostatních Václavových listinách nikde nevystupuje invokace. V̌̌echny konfirmace tak začínají intitulací: i ty jsou zcela v souladu se zvyky Václavovy kanceláře ${ }^{271}$.

Arenga byla užita při koncipování Václavových konfirmací jen jednou - v př́ípadě Vratislavi roku $1367^{272}$. Se zde uvedenou variantou jsem se nikde ve studovaném

${ }^{261}$ BU č. 204; SRS I., s. 909-910.

262 Th. L in d n e r, Das Urkundenwesen, s. 83.

263 BU č. 168, 179.

${ }^{264}$ AP Wrocław, AM Świdnicy 411, f. 3v-6r; Th. Lin d n e r, Das Urkundenwesen, s. 83 .

265 SRS I., s. 909-10.

266 I. H l a vá č e k, Das Urkunden- und Kanzleiwesen, s. 123.

267 Th. Li in d n e r, Das Urkundenwesen, s. 84.

268 BU č. 204.

${ }^{269}$ BU č. 204; SRS I., s. 909-910.

270 AP Wrocław, DM Wrocławia, č. 440, 639, 1004, 1061, 1186; AP Wrocław, AM Świdnicy 411, f. 6r-8r; O. M e in ardu s, Das Neumarkter Rechtsbuch, č. 46, 51; Codex Germaniae diplomaticus, t. II., sl. 121-123; AP Wrocław, AM Jeleniej Góry, č. 41, 53, 54, tamtéž, vidimus z r. 1655; Urkunden der Stadt Löwenberg, č. 31.

${ }^{271}$ I. H l a vá č e k, Das Urkunden- und Kanzleiwesen, s. 96-100.

272 AP Wrocław, DM Wrocławia, č. 440: Etsi ad singulorum nostrorum fidelium quos nostri ditionis latitudo conplectitur grata commoda dignamur intendere. Illis tamen uberiores favores porrigimus quorum - - fidei constantiam in procurandis nostris profectibus ab experimento didicimus notitia clariore. 
materiálu podruhé nesetkal. Jejich slabé zastoupení vcelku odpovídá i situaci v ostatních Václavových listinách ${ }^{273}$.

Přejděme k promulgaci - ta je, stejně jako v jeho českých konfirmacích, značně unifikovaná: ve všech německých kusech má formu: bekennen und tun kunt offentlichen mit diesem brive allen den die in sehen oder horen lesen, tedy přesně tu, která ovládá i jeho české konfirmace, ale která v té době dominuje privilegiím i jiných vydavatelů ${ }^{274}$. Dvě latinské konfirmace ${ }^{275}$ mají typ promulgace převládající rovněž $\mathrm{v}$ jeho jiných písemnostech a znějící Notum facimus tenore presencium universi ${ }^{276}$. Jen jediná promulgace vypadává z velmi unifikovaného rámce: nachází se v konfirmaci pro Vratislav z roku $1378^{277}$ a zní Ad perpetuam rei memoriam a je ve své době již reziduem - před tím se ve Slezsku vyskytla naposled v Karlových konfirmacích pro toto město z let 1352 a $1356^{278}$.

Naraci obsahuje většina listin, zde jen v jediné ze souboru chybí - a to v konfirmaci pro Středu z roku $1379^{279}$, kde promulgace opravdu rovnou přechází v dispozici, která má už naprosto běžnou dikci. Důvody, proč zde narace byla vynechána, neznáme, neznáme tedy ani důvody, které k vydání této listiny vedly. Stejně jako v ostatních písemnostech jím vydaných se i tady narace do značné míry podobajín ${ }^{280}$.

Konfirmační formulář v dispozici je již poměrně bohatý, slovesa jsou běžně duplikována i triplikována, nejčastěji se objevuje confirmare, approbare, ratificare, vedle toho též auctorizare - s tímto slovesem se v českých konfirmacích nesetkáváme; v německých listinách bestetigen/confirmiren, bevesten, vorneuern; nenajdeme je jen v kvasikonfirmaci vydané pro Hiršberk roku $1408^{281}$. S jedním konfirmačním slovesem vystačila jen potvrzovací listina pro Středu z roku $1392^{282}$. Setkáváme se tu také s jevem typickým pro Václavovy české konfirmacemi - duplikace potvrzovacích sloves v přítomném a minulém čase. Poprvé k tomu dochází roku 1374 v konfirmaci pro Svídnici ${ }^{283}$, poté v potvrzovací listině pro Středu z roku $1379^{284}$. Od tohoto okamžiku přichází časové zdvojování zcela pravidelně a nevyskytuje se jen na výše zmíněné atypické dispozici listiny pro Středu z roku $1392^{285}$.

Dispozice, stejně jako v Čechách, dost často začíná slovy des haben wir angesehen - - dienste. Občas se objevuje i klausule o platnosti všech ustanovení, jaká potvrzovaná listiny obsahuje, jak tomu je i ve Václavových písemnostech z českého prostředí. Užito jí bylo v osmi listinách, tedy v nadpoloviční většině. S dispoziční obratem, s nímž se ale ve Slezsku na rozdíl od Čech nesetkáváme, je iuste petentibus

${ }^{273}$ I. H l a vá č e k, Das Urkunden- und Kanzleiwesen, s. 103.

274 Tamtéž, s. 109-110.

275 AP Wrocław, DM Wrocławia, č. 440; Codex Germaniae diplomaticus, t. II., sl. 121-123.

276 I. H l a vá č e k, Das Urkunden- und Kanzleiwesen, s. 109-110.

277 AP Wrocław, DM Wrocławia, č. 639.

278 BU č. 204; SRS I., s. 909-910.

${ }^{279}$ O. M e in a rd u s, Das Neumarkter Rechtsbuch, č. 46.

${ }^{280}$ I. H l a vá č e k, Das Urkunden- und Kanzleiwesen, s. 111-112.

281 AP Wrocław, AM Jeleniej Góry, č. 53.

${ }^{282}$ O. M e in a rd u s, Das Neumarkter Rechtsbuch, č. 51.

${ }^{283}$ AP Wrocław, AM Świdnicy 411, f. 6r-8r.

${ }^{284}$ O. M e in a rd u s, Das Neumarkter Rechtsbuch, č. 46.

285 Tamtéž, č. 51. 
non sit denegandus assensus, což je vysvětlitelné velkým podílem Václavových německojazyčných konfirmačních listin, v nichž nepřichází zůstávajíc omezena jen na latinské listiny.

Sankce vystupuje $\mathrm{v}$ šesti písemnostech - svým formulářem se neliší od vzorců užívaných pro české městské př́ijemce $\mathrm{v}$ jejich konfirmacích ani v jiných Václavových listinách ${ }^{286}$.

Co se týče koroborace, převládá zde téměř naprostá unifikace. Stejně jako u českých konfirmací platí, že latinské koroborace mírně variují, zatímco německé vůbec.

Svědečná řada se nachází ve čtyřech písemnostech ${ }^{287}$, což je relativně vysoké číslo vzhledem k tomu, že v ostatních Václavových listinách se objevují jen sporadicky ${ }^{288}$. Nápadné je, že se zde koncentrují převážně do let 1408-1409, což platí i pro zkoumané konfirmace ${ }^{289}$. Tento jev je patrně třeba dávat do souvislosti s Václavovou snahou chopit se výrazněji svých vladařských povinností, které však měly jen krátkého trváníi ${ }^{290}$.

Německé konfirmace jsou pochopitelně datovány podle křest’anských svátků. Naproti tomu u třech latinských je třeba konstatovat velkou pestrost, což ale zhruba kopíruje vývoj užití této formule ve Václavově kanceláŕi ${ }^{291}$.

Tak jako v téměř všech Václavových listinách se i zde objevují relačně-konceptní poznámky přibližující účast jednotlivých členů královské rady a kanceláře na konkrétní písemnosti ${ }^{292}$.

Pokud jde o shodný formulář některých listin, jedná se vždy o písemnosti stejného př́ijemce, takže budou pojednány $\mathrm{v}$ další části, $\mathrm{v}$ níž se budeme věnovat slezským konfirmacím $\mathrm{z}$ tohoto pohledu.

Výsledkem tohoto přehledu je tak málo překvapivé zjištění: formulář konfirmačních listin ve většině formulí neprokazoval žádná specifika oproti ostatním listinám př́slušných prŕjjemců. Výjimkou jsou jedině potvrzovací listiny Jindřicha V. Tlustého, kde některé takové rozdíly přicházejí. Pro jejich výskyt ale nemáme žádné přesvědčivé vysvětlení. U ostatních zkoumaných vydavatelů, pokud se nějaké odchylky přeci jen vyskytly, jdou na vrub spíše vzniku za specifických okolností, nebo netypickému způsobu dochování takové písemnosti. V mnoha ohledech se dochované konfirmace řadí ke slavnostním privilegiím, jakkoli jejich definice není jednoznačná. Platí to především pro potvrzovací listiny dvou českých králů, kde na jejich slavnostní charakter ukazuje prítomnost některých listinných formulí, které se v ostatním listinném materiálu již pomalu vytrácely (invokace, svědečná řada). Asi jen omezeně můžeme počítat s vlivem př́ijemce na podobu dané písemnosti (u výše uvedených př́ijemců se to týkalo jen vratislavských knížat konce 13. století), což je ale otázka, která bude

${ }^{286}$ I. H 1 a vá č e k, Das Urkunden- und Kanzleiwesen, s. 115-116.

287 AP Wrocław, DM Wrocławia, č. 639, 1186; AP Wrocław, AM Jeleniej Góry, č. 53, 54.

288 I. H l a vá č e k, Das Urkunden- und Kanzleiwesen, s. 123, který uvádí celkem 30 Václavových listin se svědečnou řadou.

${ }^{289}$ Patří sem tři ze čtyř zmíněných písemností: AP Wrocław, AM Jeleniej Góry, č. 53, 54; AP Wrocław, DM Wrocławia, č. 1186.

290 I. H l a v á č e k, Das Urkunden- und Kanzleiwesen, s. 123.

291 Tamtéž, s. 127-128.

${ }^{292}$ V konceptní části se objevují: Jan z Bamberka (tamtéž, s. 411-413), František z Jevíčka (tamtéž, s. 203-207), Vlachník z Veitmile (tamtéž, s. 200-203), hlohovský děkan Jan (tamtéž, s. 151), pražský kanovník Jakub (tamtéž, s. 213-214). 
níže pojednána samostatně. Specifikem konfirmací byla podoba dispozice, která se v některých částech lišila od ostatních listin (což je ale zcela logické), v některých pasážích ale výrazně navazovala na textovou podobu listin s jiným obsahem. Právě těmto specifikům se bude věnovat další oddíl.

\section{b) celkový přehled}

Nemělo by valného smyslu podrobně rozebírat dikci zkoumaných slezských konfirmací, když je ve většině případů nemůžeme srovnávat s ostatní produkcí svých vydavatelů. Sondážně to bylo již učiněno výše i s uvedeným zjištěním. Můžeme se pokusit toto tvrzení zevšeobecnit. Konfirmační listiny se v mnohém ohledu neodlišovaly od ostatních písemností privilegiálního charakteru, někdy měly i podobu značně slavnostní listiny. To, co však smysl má, je vzájemné porovnání některých částí formuláře potvrzovacích listin napříč všemi vydavateli. Zaměříme se v následujícím výkladu především na ty pasáže, které mohly být do značné míry typické pro konfirmace a jejichž analýza má vypovídací hodnotu byt' jen v rámci této listinné kategorie.

protokol

Mnoho konfirmací, zvláště ve 13. století, začínalo ještě invokací. Až zhruba do poloviny 14. století naprosto převládají. Bez invokace jich do té doby bylo sepsáno jen málo. Po roce 1348 se naopak invokace vyskytují zřídka - jen sedm konfirmací oproti 28 bez ní. Mezi př́jemci oněch sedmi kusů často vystupují města lehnického knížectví. Mezi listinami obsahujícími invokaci očekávaně převažují latinské kusy, německých je jen nemnoho ${ }^{293}$.

Pokud se vyskytla invokace, ve většině př́ípadů obsahovala daná listina i arengu, i když to nebylo úplným pravidlem. Objevuje se několik málo výjimek. I po roce 1348, kdy klesá frekvence invokací, ji vesměs doplňuje i arenga - většinou se v konfirmacích objevují pospolu, ale opět jsou i výjimky, kdy v listině stojí arenga bez invokace ${ }^{294}$, stejně jako invokace bez arengy ${ }^{295}$. První př́ípad se objevuje pouze u Vratislavi jako prŕjemce, druhý jen u Goldberku.

text

Na počátku klíčové části formuláře může stát arenga, jejíž výskyt s postupujícím časem klesá, což je všeobecný jev, který lze pozorovat pro slezské prostředí a probíhá i mnohde jinde ${ }^{296}$. Arenga se objevuje ve všech konfirmacích do roku 1290.

${ }^{293}$ Nejčastěji má formu In nomine domini amen, v německých listinách In gotis namen amen. Jiné znění mají jen konfirmace Jindřicha IV. Vratislavského pro Vratislav z roku 1282: In nomine dei eterni amen (SUb V., č. 66.) a potvrzovací listina Karla IV. pro totéž město $\mathrm{z}$ roku 1356: In nomine sancte et individue Trinitatis feliciter Amen (SRS I., s. 909-910).

${ }^{294}$ BU č. 204; AP Wrocław, DM Wrocławia, č. 440 (KDPAPDS V., č. 75).

295 AP Wrocław, rewp. 132a, dep. miasta Zlotoryi, č. 81, 83.

${ }^{296}$ Ke staršímu období vývoje areng slezských knížat viz T. N o w a k o w s k i, Idee areng dokumentów książąt polskich do połowy XIII wieku, Bydgoszcz 1999, s. 87-132. Arengy z období zkoumaného Nowakowskim se v mnou analyzovaném materiálu nevyskytovaly. Jen u dvou lze hovořit o částečné shodě, kdy je však identická jen menší část arengy: Zaprvé šlo o konfirmaci Jindřicha Proba pro Vratislav z roku 1276 (SUb IV., č. 282), jejíž začátek byl stejný jako u arengy listiny kněžny Hedviky pro třebnický klášter z roku 1242 (SUb II., č. 234; T. N o w a k o w s k i, Idee, s. 89-90). Zadruhé to byla arenga konfirmace Konráda Zaháňského 
V potvrzovacích listinách Jindřicha $\mathrm{V}$. byla užívána méně, ale $\mathrm{v}$ druhém a třetím desetiletí 14. století se s ní setkáváme znovu častěji. Od 70. let 14. století její užívání velmi výrazně klesá, což souvisí se změněným jazykovým charakterem konfirmací (viz dále). Od té doby do konce sledovaného období přicházejí již jen tři listiny, které ji obsahují: dvě pro Lehnici'in, jedna pro Kožuchov ${ }^{298}$.

Vyjádřeno celkově: arenga se objevuje $\mathrm{v}$ jedné třetině slezských konfirmací, což je o něco více, než tomu bylo u českých potvrzovacích listin - tam to byla zhruba jedna čtvrtina ${ }^{299}$.

V. Konfirmační listiny s arengami a bez nich

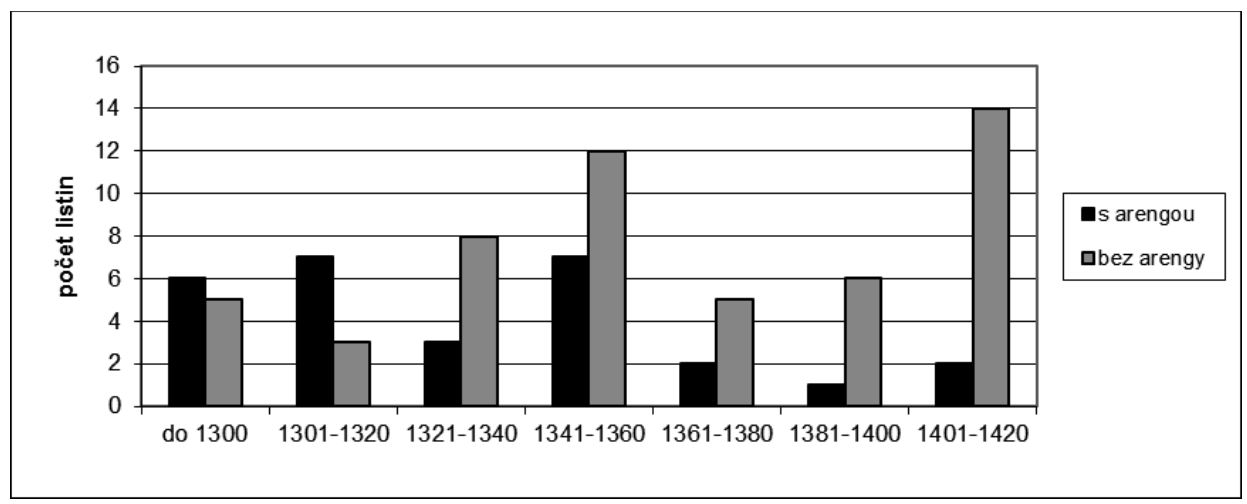

Po jazykové stránce naprosto dominují latinské konfirmace, ve sledovaném souboru bylo jen jediné německé potvrzovací privilegium $\mathrm{s}$ arengou ${ }^{300}$. To je ostatně jev, který je znám již dlouho. Ve slezském prostředí nabývá ale nadvláda latinských kusů $\mathrm{s}$ arengami vůči německým skutečně výrazné převahy. Jakkoliv i v českém prostředí byla převaha latiny $\mathrm{v}$ tomto ohledu značná ${ }^{301}$, přeci jen nenabyla takových rozměrů jako zde.

Délka areng je různá, průměrně se dá říci, že se postupem času nezkracuje ani neprodlužuje. Objevují se kratší i delší, nejdelší arenga se nachází ve dvou konfirmacích pro Vratislav z let 1352 a $1356^{302}$. Celkově je jejich délka kratší, než tomu bylo u českých listin a konfirmacín ${ }^{303}$.

pro Šprotavu z roku 1304 (USUS, č. 104) a listina Jindřicha Bradatého pro vojvodu Teodora Z roku 1237 (SUb II., č. 137; T. N o w a k o w s k i, Idee, s. 103).

297 UBSL č. 313; AP Wrocław, DM Legnicy, č. 226.

298 AP Wrocław, rep., 132a, dep. m. Kożuchowa, č. 6.

${ }^{299}$ K arengám listin pro česká královská města viz T. Ve li č k a, Die Arengen königlicher Urkunden in Böhmen 1310-1419: Das Beispiel der für Städte ausgestellten Urkunden, v: Urkundenformeln im Kontext. Formen der Schriftkultur im Ostmitteleuropa des Mittelalters (13.-14. Jahrhundert), Wien 2016 (Veröffentlichungen des Instituts für Österreichische Geschichtsforschung 65), s. 61-93.

${ }^{300}$ AP Wrocław, rep. 132a, dep. miasta Kożuchowa, sign. 6.

301 T. Ve li č k a, Die Arengen, s. 66-67.

302 BU č. 204; SRS I., s. 909-910.

${ }^{303}$ T. Veli č k a, Die Arengen, s. 68. 
Pokud jde o obsahové hledisko areng, je možné je rozčlenit do několika kategorií. Jako první pojednejme o arengách majestátních.

$\mathrm{V}$ jejich rámci se objevuje několik témat. Jako první je to péče o poddané ${ }^{304}$, s níž se lze setkat celkem v devíti konfirmacích po celé sledované období. Nejstarší kus s takovou arengou pochází z roku $1277^{305}$, nejmladší z roku $1367^{306}$. Od 70 . let 14. století se už sice neobjevuje, ovšem od tohoto desetiletí, jak výše uvedeno, zaznamenávají arengy značný ústup z dochovaných konfirmací a na tento úsek připadají jen tři kusy, kam byla zapsána, jež ovšem patři do jiných obsahových skupin areng.

Na rozdíl od areng vzniknuvších pro české př́ijemce se ve slezském materiálu dočítáme jen o poddaných obecně. Vủbec tu nejsou tematizována města jako celek - jako specifičtí poddaní knížete. Nejspíš se v tom odráží pevnější postavení českých královských měst, ještě nikoliv jako stavu, ale přeci jen jako určité sevřenější skupiny, s níž panovník nakládal. I to svědčí o tom, že arengy nebyly tak úplně strnulou formulí a že do určité míry odrážely realitu doby, v níž bývaly používány. Další moment, který stojí za pozornost, je výskyt pojmu Koruny království českého, který se objevuje ve dvou arengách vydaných pro Vratislav Karlem IV. v letech 1352 a $1356^{307}$. Jinde se neobjevil. Zde je třeba dodat, že nebylo ani více př́ležitostí, nebot' Karel už nevydal pro slezská města žádnou jinou konfirmaci s arengou a Václav jen jedinou, která ji obsahovala, a to ještě v dobách svého dětstvín ${ }^{308}$. Ta se však poněkud odlišovala, i když tematicky se s výše zmíněnou arengou Karlovou v lecčems stýká.

Rejstřík témat je pochopitelně blízký arengám v českých konfirmačních listinách. Lze se v nich dočíst, že věrní poddaní mají být odměňováni, panovník se má starat o jejich blaho atd ${ }^{309}$.

Zadruhé se zde setkáváme $\mathrm{s}$ tématem veřejného pořádku v úzkém sepětí s péčí o poddané. To je prípad areng dvou listin ${ }^{310}$. V prvním případě, konfirmaci pro Vratislav z roku 1310, čteme o rovnítku mezi náklonností a milostí vydavatelů a cestě práva, na niž je potřeba se vydat ${ }^{311}$. Stejně i druhá listina, v níž toto téma zaznívá -

${ }^{304}$ SUb IV., č. 307, V., č. 66; UBSL č. 38, 140, 195; CDS IX., č. 11; BU č. 204; SRS I., s. 909-910; AP Wrocław, DM Wrocławia, č. 440 (KDPAPDS V., č. 75).

${ }^{305}$ SUb IV., č. 307: Ea, que ex principum beneplacito ad subditorum commoda conceduntur, aliquociens sibi renovacionis remedio indigent subveniri, ut ea, que vetera sunt, wltum novitatis assumendo pociorem adhibicionem fidei conquirant et maioris gaudeant fulcimine firmitatis.

306 AP Wrocław, DM Wrocławia, č. 440: Etsi ad singulorum nostrorum fidelium quos nostri ditionis latitudo conplectitur grata commoda dignamur intendere. Illis tamen uberiores favores porrigimus quorum - - fidei constantiam in procurandis nostris profectibus ab experimento didicimus noticia clariore.

307 BU č. 204; SRS I., s. 909-910: Quamvis innata cordi nostro benignitas ad universorum fidelium, quos nostre potestatis dicio circumquaque complectitur, utilitates et commoda procuranda piis et graciosiis inclinetur favoribus, ad illorum tamen profectus quadam singulari clemencia specialius dignamur intendere, qui ad nostre maiestatis honorem flagrantioribus votis aspirant, quosque in regni et corone serviciis fidei promptitudine et mentis immota constantia invenimus continuo poriores.

308 AP Wrocław, DM Wrocławia, č. 440.

309 Blí̌̌ viz T. Ve li č k a, Die Arengen, s. 71-73.

310 BU č. 89; AP Wrocław, DM Legnicy, č. 226.

311 Cum iuris tramite condocente hos expediat maiore fauoris et gracie amplitudine prosequi, qui se digniores apud nos fidelitatis merito et gratitudine constancie reddiderunt. 
konfirmace pro Lehnici knížete a biskupa Václava II. z roku 1409, je na hraně mezi předchozí skupinou a touto ${ }^{312}$. Vydavatel $\mathrm{v}$ arenze oznamuje, že shledává zbožným a spravedlivým zachovávat práva civitatum nostrarum - to je zároveň jediná arenga, kde se ozývá péče o města jako celek. Výše bylo zmíněno, že ta se jinak ve studovaných slezských arengách nevyskytuje.

Druhý obsahový typ zkoumaných areng představuje náboženská tématika. Máme s ní co do činění ve třech konfirmacích ${ }^{313}$. Arenga privilegia Jindřicha Javorského pro Javor z roku 1344 je velmi zajímavá a stojí za to ocitovat ji v úplnosti: Homo natus de muliere breui vivens tempore in extremo articulo vite positus transactis multis miseriis et erumnis necessario debet conquirere merita quibus auxilia iis meretur accipere gaudia futurorum, que nec oculus vidit nec auris audivit, nec unquam actus interioris hominis comprehendit ${ }^{314}$. Její počátek je plně převzat ze starozákonní Knihy Jób (14: 1-2). Zaznívá tu pomíjivost pozemského života a touha po spáse a věčném životě. Arenga sama má prímou souvislost s obsahem listiny, nebot' v ní Jindřich potvrzoval zrrízení špitálu ve městě. Dlužno dodat, že s podobně tematicky utvářenými arengami se lze setkat i v českém prostředí právě v listinách, které se nějak týkaly městských špitálů ${ }^{315}$.

Výrazně kratší je arenga Bolkovy konfirmace určené Svídnici: Quia bone reo peram dare ex presentis vite habet mericium pariter et future ${ }^{316}$. Ozývají se v ní stejné motivy jako v Jindřichově listině. Opět šlo o potvrzení týkající se městského špitálu - Bolek tu konfirmoval dohodu mezi svídnickými radními a vratislavským a svídnickým konventem kř́žzovníků s červenou hvězdou.

V poslední listině této skupiny, konfirmaci vévody Ruprechta pro Lehnici z roku 1380, zaznívá více témat - její priiřazení do určité skupiny proto nebylo jednoduché. Objevuje se tu péče o poddané, následování předků, ale také spása poddaných ${ }^{317}$.

Nejčastěji byly ve sledovaném materiálu zastoupeny arengy třetího typu, v nichž se objevuje starý motiv memoria-oblivio ${ }^{318}$. Jinými slovy nutnost sepsání př́slušného právního aktu pro to, aby nebyl zapomenut, nebot' lidská pamět' je krátká a nestálá. Často se takové arengy vyskytují na počátku sledovaného období, ale nemizí ani později. Až do 20. let 14. století byl zmíněný motiv užíván hojně, pak však téměř úplně mizí (až na konfirmaci Jana Stínavského z roku 1348) ${ }^{319}$ a objevuje se znovu

312 Iuste et pie nos facere deputamus cum iura civitatum nostrarum rei publice conservamus.

${ }^{313}$ Ch. F. E. F i s c h e r, Geschichte und Beschreibung der schlesischen Fürstentumshauptstadt Jauer, t. I., Jauer 1803, s. 219-221; AP Wrocław, rep. 6a, č. 149; UBSL č. 313.

314 Ch. F. E. F is c h e r, Geschichte, t. I., s. 219-221.

315 T. Veli čk a, Die Arengen, s. 74.

316 AP Wrocław, rep. 6a, č. 149.

317 UBSL č. 313: Vt ea, que graciose, racionabiliter et, pie a progenitoribus nostris pro comodo, pace et salute subditorum gesta cognouimus, amplioris gracie et fauoris prosequamur augmento, reipublice ac propria nos vtilitas admonet et hortatur.

318 SUb IV., č. 282, 284, 300, V., č. 461; USUS,s. 104, 129, 134, 159; BU č. 76; UBSL č. 49; Urkunden der Stadt Löwenberg, č. 31; AP Wrocław, rep. 132a, dep. miasta Kożuchowa, č. 6.

319 USUS, s. 159: Ne ea, que aguntur in tempore, simul cum tempore a memoria hominum decidant, decet, ut discretorum subsidio ac literarum testimonio nec non sigillorum robore confirmatur. 
solitérně až v kožuchovské konfirmaci v roce 1419 - jednalo se, jak bylo řečeno, o jedinou německou arengu ve zkoumaném souboru ${ }^{320}$.

Na rozdíl od českého prostředí byla ve Slezsku tato témata živá ještě v 1. třetině 14. století. V kanceláři Jana Lucemburského nebyly arengy memoria-oblivio do jeho listin pro královská města téměř nikdy zařazovány a později již vůbec ${ }^{321}$.

Arengy se ve sledovaných listinách opakují jen málo, lze nalézt jen tř̆i listinné dvojice, kde bylo užito identického vzorce.

První je konfirmace Jindřicha IV. Vratislavského Cuncta, que geruntur in tempore, vacillant facile, nisi scripture presidio et testium aminiculo roborentur ad gestorum memoriam sempiternam, která se nachází v listinách pro Grodkov a Svídnici z roku $1276^{322}$. Obě listiny se svým formulářem částečně shodují a obě potvrzují držbu lesa př́islušným městem. Tato arenga se podobá jedné $\mathrm{z}$ areng užívané $\mathrm{v}$ kanceláři Vladislava Lokýtka ${ }^{323}$.

Zopakovala se rovněž arenga Pii principis interest subditorum commodis ita intendere, vt possint habunde eius patrocinio gratulari, a to $\mathrm{v}$ kanceláři Boleslava III. v konfirmacích pro Lehnici a Břeh z roku $1314^{324}$.

Dvakrát byla použita ještě arenga Quamvis innata cordi nostro benignitas ad universorum fidelium, quos nostre potestatis dicio circumquaque complectitur, utilitates et commoda procuranda piis et graciosiis inclinetur favoribus, ad illorum tamen profectus quadam singulari clemencia specialius dignamur intendere, qui ad nostre maiestatis honorem flagrantioribus votis aspirant, quosque in regni et corone serviciis fidei promptitudine et mentis immota constantia invenimus continuo puriores ve dvou Karlových konfirmacích pro Vratislav z let 1352 a $1356^{325}$. Obě listiny se téměř zcela shodují také v dispozici, v ostatních formulích již méně.

U promulgací je jejich textová podoba velmi pestrá, tak jak odpovídalo úzu jednotlivých knížecích kanceláří. Výraznější unifikaci pozorujeme od 70. let 14. století u promulgací německých potvrzovacích listin.

Trendy potvrzovacího formuláře listinných dispozic jsou obdobné jako v Čechách. Postupně dochází ke kumulaci konfirmačních sloves, jejich zdvojování, ztrojování, někdy i zčtverování. Stejně tak tu přichází duplikace konfirmačních sloves v minulém a přítomném čase, která se ponejvíce objevuje v konfirmacích Václava IV., ale je patrná i jinde.

Sankce se častěji objevuje jen v konfirmacích vydaných českými panovníky, přímo slezští vydavatelé ji do svých konfirmací zařazovali velmi zřídka.

${ }^{320}$ AP Wrocław, rep. 132a, dep. miasta Kożuchowa, č. 6: Wenne alle ding und sachen die do geschen in der czeit vorgeslich und vorgenglich sein, czo ist notdorst die ding die do lange waren sullen zu bestetigen mit offenbrieven und mit vorhastigen geczeugen.

321 Arengy se v konfirmacích Jana Lucemburského pro slezská města dokonce vůbec nevyskytují (T. Ve li č k a, Die Arengen, s. 74).

322 SUb IV., č. 284, 300.

${ }^{323}$ A. A d a m s k a, Arengi w dokumentach Władysława Łokietka, Kraków 1999, s. 134 (doložena pro léta 1298 a 1299).

324 UBSL č. 38; CDS IX., č. 11.

325 BU č. 204; SRS I., s. 909-910. 
e s chatokol

Eschatokol obvykle začínal koroborací. Opět je třeba rozlišovat jazykově latinské a německé konfirmace. Ve 13. a 1. polovině 14. století byla dosti oblíbená forma In cuius/huius rei testimonium ${ }^{326}$, výrazně méně se objevují koroborace Presentem paginam $^{327}$, a Harum nostrarum testimonio literarum. V konfirmacích Karla IV. a Václava IV. je užívána v podobě presencium sub nostro maiori sigillo testimonio literarum, ale to je již na začátku období, kdy začínají dominovat německé konfirmace.

V německých konfirmacích Václava IV. od 70. let 14. století nejčastěji vystupuje forma Mit urkund dicz brives vorsigelt mit unserer kuniglichen maiestat insigel. Ve Slezsku se ale v jiných kancelářích plně neprosadila a u jiných vydavatelů se tak užívaly spíše jiné varianty: Des zu ganzir/grosser sicherheit, Czu sicherheit, Der czu rechter wissen.

Až do poloviny 40. let 14. století se svědečná řada objevuje zcela běžně, poté méně, ale stále v nezanedbatelné míře. Zatímco čeští králové ji užívali málo, pro slezské vydavatele byla téměř nutnou součástí, i když najdeme několik výjimek. Proto od 40. let přichází méně. Je to doba, kdy stoupá emise konfirmačních listin Karla IV. pro slezská města a tím zdánlivě o něco klesá její využití - je to ale způsobeno právě tím, že v královských konfirmacích se nacházely méně. I to je jeden z dalších rozdílů konfirmačních listin domácích-slezských vydavatelů a českých králů.

V potvrzovacích listinách pochopitelně téměř nikdy nechyběla datace. V nejstarším období se datuje pomocí rímského kalendáře. Poprvé je latinská konfirmace datována křest'anskými svátky roku $1294^{328}$ a od té doby převažuje, i když občas se ještě lze setkat s ř́mským kalendářem. Křest’anský kalendář tedy proniká do slezského konfirmačního materiálu dříve než v Čechách a nahrazuje římské datování. Německé kusy jsou datovány podle svátků křest’anského kalendáře.

Poslední formulí, o níž budu mluvit, je kancelářská poznámka. Relačně-konceptní poznámky se běžně objevují především v konfirmacích Václava IV. pro slezské příjemce. Je k dispozici více konfirmací slezských knížat, které kancelářské poznámky obsahují, než těch, které ji neměly. Důvod jejich lepšího dochování spočívá i v tom, že v kancelářích slezských knížat bývaly vesměs součástí hlavního textového bloku listin a nebyly psány mimo něj, jako tomu bylo v české královské kanceláři. Při opisech se často na poznámky psané mimo hlavní text nebral zřetel.

\section{c) podle př́ijemců}

Formulář sledovaných konfirmací lze rovněž hodnotit z pohledu jejich prŕijemců a zkoumat př́ípadné vzájemné shody jednotlivých kusů.

Jediná dvě města, kde se dá pozorovat vzájemná textová shoda a závislost konfirmačních listin, jsou Vratislav a Lehnice. U obou přichází textová závislost konfirmací

${ }^{326}$ Pokračování této formule mohlo být různé, např́íklad: (In cuius rei testimonium) et cautelam presentes fieri et nostri sigilli fecimus munimine communiri; (In cuius rei) evidenciam pleniorem nostrorum omnium sigilla presentibus sunt appensa; (In cuius rei testimonium) presentibus nostrum sigillum est appensum atd.

327 Opět se tu objevují různé varianty, například: presentem paginam ad evidenciam clariorem conscribi iussimus et sigilli [nostri munimine commun] iri; presentem paginam robore nostri sigilli iussimus communiri.

328 SUb VI., č. 140. 
se 40. lety 14. stoletín $^{329}$. Zatímco v prípadě Lehnice se tento trend do dalších desetiletí nepřenesl, v potvrzovacích listinách pro Vratislav trvá i nadále. Konfirmace pro Lehnici vydané následujícími dvěma zeměpány prokazovaly jen souvislost mezi sebou, resp. závislost druhé (z roku 1409) ${ }^{330}$ na předchozí (z roku 1380) ${ }^{331}$. Text Ruprechtovy konfirmace $\mathrm{z}$ roku 1380 se tak neinspiroval předcházejícími. Naproti tomu konfirmace pro Vratislav byly mezi léty $1348-1356^{332}$ a $1377-1378^{333}$ psány podle jednotné předlohy. Proč se i dále v této tendenci ve Vratislavi nepokračovalo? Důvod spočíval v jazyce, $v$ jakém byly následující konfirmace sepsány - byla to již němčina. U dvou německých všeobecných konfirmací z let 1404 a 1409 lze opět pozorovat jisté shody ${ }^{334}$.

To, čím byla podpořena možnost převzetí listinného formuláře z předchozí konfirmace, byl jistě i charakter toho, co se potvrzovalo. V téměř všech případech textových shod jak vratislavských, tak lehnických písemností šlo o všeobecné konfirmace - tedy takové potvrzovací listiny, které aprobovaly znění všech privilegií daných městu. O všeobecné konfirmace se nejednalo ve dvou lehnických konfirmacích let 1380 a 1409 - v obou prrípadech však byly vystaveny potvrzovací listiny, které inserovaly svou konfirmační předchůdkyni (která byla všeobecnou konfirmací).

Z uvedeného krystalizuje několik podmínek nutných pro vzájemnou podobnost konfirmací udělených týmž př́jemcům. Z počátku existence takových písemností vyplývá, že k tomu byl potřebný určitý stupeň byrokratizace městské kanceláře, či snad (také) kanceláře vydavatelovy. Již výše jsem hovořil o vydavatelově a př́ijemcově aktivitě při zisku konfirmačních listin. Zaznělo tam, že př́jemce předkládal nejspíš originály listin, jež žádal potvrdit. S tím tedy souvisí další podmínka: takový stav městského archivu, který př́slušné písemnosti umožnil uchovat.

Neméně důležitým předpokladem byl stejný předmět potvrzení. Ve městech (či v knížectvích), kde se neujala tradice potvrzování listin nově nastupujícím panovníkem, pak tato podmínka chyběla. Vedle toho byl rovněž důležitý stejný jazykový charakter potvrzovacích listin - tam, kde došlo k přechodu od latiny k němčině, byl formulář konfirmací pro jednoho př́jemce vždy přerušen, jakkoliv se mohlo jednat svým obsahem o podobné písemnosti.

\section{Druhy konfirmací}

Přišel čas povšimnout si poněkud podrobněji některých dalších aspektů studovaných konfirmačních listin, předmětu potvrzení a řeč bude rovněž o polokonfirmacích.

Mezi zkoumanými slezskými konfirmacemi se nacházela pestrá škála právních aktů, které byly potvrzovány. V platnosti zůstává i zjištění, že mezi zkoumanými konfirmacemi převládají potvrzení právních aktů zeměpánů.

V počátečním období se nesetkáváme s ničím jiným než právě s potvrzením právních aktů předchůdce vydavatele př́islušné konfirmace. Poprvé přichází potvrzovací

329 SR č. 6915 ; UBSL č. $140,145$.

330 UBSL č. 438.

331 UBSL č. 313.

332 BU č. 190, 204; SRS I., s. 909.

333 AP Wrocław, DM Wrocławia, č. 12586, 639.

334 Tamtéž, č. 1061, 1086. 
listina konfirmující právní akt poddaných roku 1315 - Boleslav III. tehdy potvrdil Lehnici koupi pozemkư ${ }^{335}$. Více takových př́padů se objevuje od 30 . až do počátku 50. let 14. století, ale početně stále převládají konfirmace panovnických aktư ${ }^{336}$. Konfirmace nepanovnických právních pořízení se týkají bud' městských transakcí $\mathrm{s}$ nemovitostmi, fundace špitálu, anebo sporů uvnitř města, nebo $\mathrm{s}$ církevní institucí. Poté až do 80 . let 14 . století tento druh konfirmace opět nepríichází a lze se s ním setkat až v závěru století. Nejvíce se jich koncentruje do 90 . let 14 . stoletîi37. Na konfirmační produkci se tyto potvrzovací listiny podílely tehdy stejnou měrou jako konfirmace právních aktů zeměpána. Jsou vydávány v podobných záležitostech jako před polovinou století. Rovněž žádný z vydavatelů nepřevládá, takže nelze zvýšený výskyt těchto konfirmací spojit s žádnou z tehdejších knížecích (nebo hejtmanských/ královskou) kancelárí. Řada těchto písemností je na hraně s konsensními listinami.

Konfirmace tedy byly vydávány zpravidla $\mathrm{v}$ záležitostech potvrzení právních aktů předchůdců vydavatele, ačkoliv existují výjimky. Ve Slezsku mají své místo především v závěru 14. století. Znovu tu ale do celkové situace promlouvá fakt, že se řada $\mathrm{z}$ nich nedochovala $\mathrm{v}$ plnotextovém znění. $\mathrm{V}$ některých př́ípadech je třeba vystačit $\mathrm{s}$ více či méně precizními regesty a spolehnout se na ně. Nedá se proto vyloučit, že některé z těchto kusů ani nebyly konfirmacemi, avšak skutečný stav věci, kdy originál nebo plnotextový opis již není k dispozici, je nezjistitelný. Přesto jsem ve sporných př́ípadech písemnost mezi konfirmace zařadil, byt' si zcela uvědomuji nepevnost tohoto soudu.

I z počátku 15. století je známo několik takových konfirmací, i když jejich počet není tak vysoký jako v závěru 14. stoletî́338. Téměř všechny se vydavatelsky vztahují ke svídnicko-javorským hejtmanům ${ }^{339}$.

Samostatným problémem je otázka insertních a bezinsertních konfirmací. V počátcích existence konfirmačních listin pro města ve Slezsku nejsou insertní konfirmace výjimkou. Nejstarší vydal již roku 1283 Jindřich IV. Vratislavský pro své sídelní město $^{340}$. Velmi často vycházely insertní potvrzovací listiny z kanceláře Jindřicha V. Tlustého. V tom se lišil od svých současníků i nejbližších následovníkư ${ }^{341}$ : jejich prŕjemcem byl dvakrát Břeh a jednou Vratislav. Další insertní konfirmace vznikla roku 1307, ale zde šlo o solitér - vydavatelem byl nadto braniborský markrabě Heřman z titulu poručníka nedospělých synů Bolka I. Surového (Svídnického) ${ }^{342}$. Několik jich

335 SR č. 3533.

336 UBSL č. 114; RŚl I., č. 243, 660; O. M e i n a r d u s, Das Neumarkter Rechtsbuch, č. 34.

337 AP Wrocław, rep. 132a, Urkunden der Stadt Ohlau, č. 29 (originál není dochován); Th. L i n d n e r, Aus dem Archive der Stadt Jauer, s. 93, č. 76; AP Wrocław, rep. 132a, dep. miasta Chojnova, č. 45 (podle předválečného archivního inventáře, originál se nezachoval); AP Wrocław, rep.132a, dep. Złotoryja, č. 69 (na základě inventáře, originál se nedochoval); AP Wrocław, AM Wrocławia, D 24, f. 59v (jde jen o regest); AP Wrocław, rep. 132a, dep. miasta Chojnowa, č. 49, 50 (originál nedochován); G. S c h u l z, Ohlaus Vergangenheit, s. 170 (jen zmínka); AP Wrocław, rep. 132a, dep. miasta Dzierżoniowa, č. 45.

${ }^{338}$ Landbuch III., č. 1647, 1687; CDS XXIV., s. 3, č. 3; Urkunden der Stadt Löwenberg, č. 33.

339 Jako předchozí pozn. kromě CDS XXIV., s. 3, č. 3.

340 SUb V., č. 66.

341 SUb V., č. 467, VI., č. 46, 140.

342 SR č. 2960 (pro Frankenštejn). 
přichází po roce 1319, ale jejich celkové počty jsou velmi nízké, zvláště v porovnání s posledním desetiletím 13. století, kdy inserty do svých potvrzovacích listin často zařazoval Jindřich V. Tlustý.

Největší propast mezi insertními a bezinsertními konfirmacemi lze zaznamenat ve 40. letech, kdy byly vydány jen tři insertníi ${ }^{343}$ oproti šestnácti bezinsertním potvrzovacím listinám. Podobně nízké zastoupení insertních konfirmací trvá i během 50 . let, ale k jejich výraznému nárůstu potom dochází od počátku let 60 . V 60., 70. a 90. letech 14. století insertní konfirmace převažují (v 80. letech jsou oba druhy v rovnováze). V prvním desetiletí 15. století se počet insertních i bezinsertních kusů vyrovnává a z posledního sledovaného desetiletí jsou k dispozici již jen bezinsertní. Do určité míry to souvisí se změněnou strukturou vydatelů konfirmací, jak se do dnešních dnů zachovaly. V letech 1410-1419 již mezi nimi např́klad chybí Václav IV., který byl vydavatelem velkého množství insertních listin. Zda šlo tehdy o krátkodobý výkyv v neprospěch zařazování insertů, nebo o počátek dlouhodobé tendence, není možné říci. Bádání po roce 1419 jsem neprováděl.

Předchozí výklad shrnuje následující graf. K němu je potřeba říci, že součet insertních a bezinsertních konfirmací v rámci jednotlivých desetiletí často neodpovídá jejich počtu, jak byl uveden výše v celkovém přehledu. Je to dáno řadou listin nedochovaných v plném znění, kde nelze rozhodnout, zda dotyčný kus obsahoval insert, či nikoliv. Vedle insertních a bezinsertních konfirmací se ve sledovaném materiálu občas vyskytl i typ zmínkové insertní konfirmace - taková není v plném textu citována, ale je pouze shrnut její obsah. Takový typ může mít několik mezistupňů, od prosté několikaslovné zmínky, až po podrobné shrnutí listinné dispozice. Takový případ představuje potvrzovací listina Jana Krušiny z Lichtenburka pro Lemberk z roku $1407^{344}$. Tato listina není do následujícího přehledu započítána. Jindy, pokud šlo o pouhou zmínku bez výraznějšího rozvedení obsahu, jsem př́slušný kus zahrnul mezi bezinsertní konfirmace.

VI. Insertní a bezinsertní zeměpanské konfirmace pro slezská města

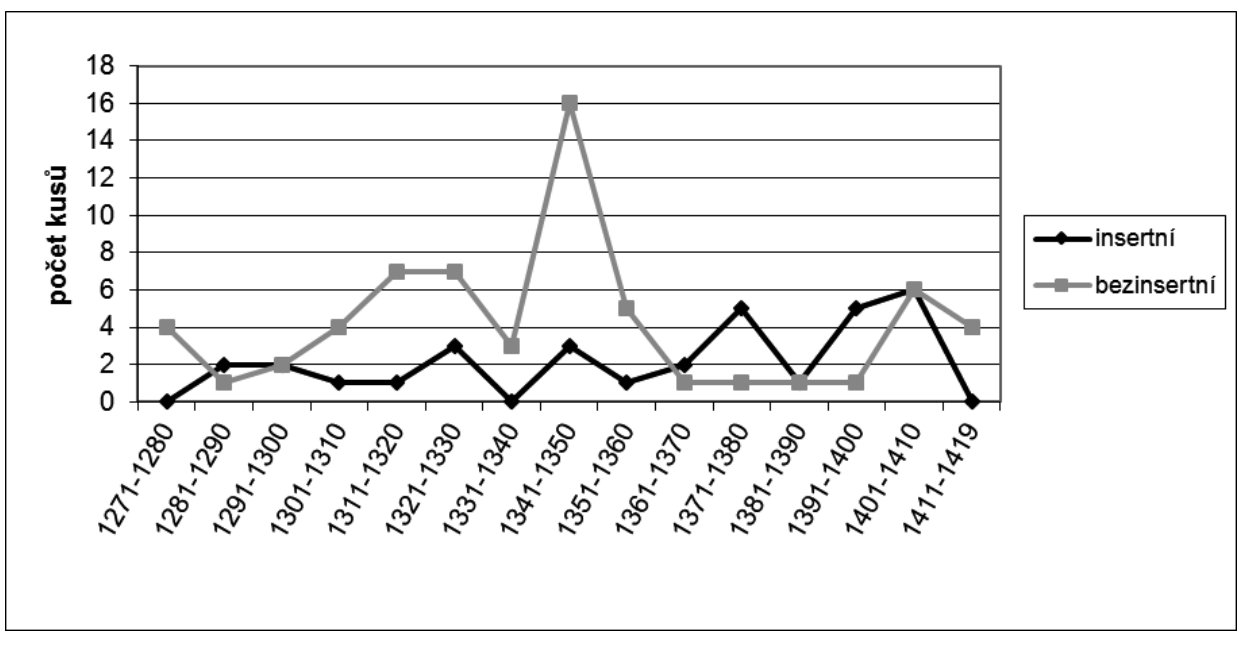

${ }^{343}$ BU č. 177, 179; RŚl II., č. 24.

${ }^{344}$ Urkunden der Stadt Löwenberg, č. 30. 
Srovnejme z tohoto hlediska jednotlivé vydavatele. Vzhledem k tomu, že bezinsertní konfirmace byly ve sledovaném materiálu dvakrát četnější než jejich insertní protějšky, je logické, že i mezi vydavateli převládají ti, kteří měli „na svědomi““ potvrzovací listiny bez insertu než s ním. Ve slezských knížecích kanceláríich se tak zvyk vpisovat text konfirmované písemnosti do konfirmace příliš neprosadil. Vydavateli insertních potvrzovacích listin tu byli především čeští králové a jejich hejtmani. Výjimky mezi slezskými knížaty představovali jedině Jindřich V. Tlustý a Anežka Svídnická. Jde tedy o celkem zajímavé zjištění, které však bylo provedeno jen na př́kladu jedné prŕijemecké skupiny. Zda-li se jednalo o všeobecnou tendenci ve slezských kancelářích, by zodpovědělo jen podrobnější studium.

Největší časový odstup mezi vydáním konfirmace a potvrzované listiny je patrný z konfirmační listiny svídnicko-javorského hejtmana Jana Krušiny z Lichtenburka z roku 1407 pro Lemberk, kde vystupuje potvrzována listina Jindřicha Bradatého (šlo o falzum). Nejčastěji ale bývaly aprobovány písemnosti bezprostředních předchůdců. Starší vrstva konfirmací, kdy aktuální vydavatel potvrzoval písemnost předchůdce svého předchůdce (ob jednu generaci), již není příliš četná. Př́iležitostně ale lze nalézt potvrzovací listiny, jež konfirmují výrazně starší písemnost. Řeč byla o Krušinově potvrzení údajné listiny Jindřicha Bradatého. Větší odstup byl rovněž mezi konfirmační listinou Jana Lucemburského z roku 1343, v níž potvrzoval písemnost Jindřicha III. z roku 1263. Roku 1357 zase Karel IV. potvrdil Krapkovicím listinu Bolka I. Opolského z roku $1294^{345}$. Roku 1362 potvrzoval Bolek II. Svídnický listinu Jindřicha IV. Vratislavského datovanou na rok 1283. Leč to jsou všechny př́ípady, kdy je aprobována časově vzdálenější písemnost. Zpravidla šlo skutečně o konfirmace listin, které byly staré několik málo desítek let (a někdy ani to ne).

Do jaké míry slezští vydavatelé konfirmací spojovali potvrzení listiny/listin s jinými právními akty a vydávali tak tzv. polokonfirmace? Tento druh potvrzovacích listin se ve slezském materiálu vyskytuje zhruba stejně často, jako tomu bylo v Čechách. Přichází tu 27 takových písemností, které jsou rozvrženy do celého zkoumaného období $^{346}$. Přesto lze pozorovat úseky, kdy byly v užívání více: nadprůměrné množství jich připadlo na léta 1314-1326, stejně jako na 40. léta 14. století. Po roce 1360 až do konce zkoumaného období jich bylo vydáno méně než v předchozích dekádách. Žádné nevznikly od přelomu 50. a 60 let do př̀lomu 70. a 80. let 14. století.

Mezi jejich vydavateli se nejčastěji objevuje Boleslav III. ${ }^{347}$, častěji je vystavoval ještě Václav IV. ${ }^{348}$ a Karel IV. ${ }^{349}$ U Boleslava tvořily polokonfirmace třetinu všech jeho potvrzovacích listin, u Václava IV. to bylo jen o něco méně, u ostatních pak představovaly méně než čtvrtinu. Řada zkoumaných vydavatelů nevystavila

${ }^{345}$ RŚl III., č. 500.

346 SUb IV., č. 307, VI., č. 427; SR č. 2864, 3392, 3395, 3593, 3614, 4138, 4304, 4545, 5142, 5467; RŚl I., č. 34, 243, 709, 713, II., č. 11, 618, III., č. 310; AP Wrocław, DM Wrocławia, č. 12586, 639 (KDPAPDS V., č. 647), 1167; AP Wrocław, DM Świdnicy, č. 258 (CDS XXVII., s. 180-181, č. 14); Codex Germaniae diplomaticus, t. II., sl. 121-123, č. 13; AP Wrocław, AM Jeleniej Góry, vidimus z roku 1655; Urkunden der Stadt Löwenberg, č. 31; RDPGŚ II., č. 200.

347 SR č. 2864, 3392, 3395, 3593, 4304, 4545.

348 AP Wrocław, DM Wrocławia, č. 12586, 639 (KDPAPDS V., č. 647), 1167; AP Wrocław, AM Jeleniej Góry, vidimus z roku 1655; Urkunden der Stadt Löwenberg, č. 31.

${ }^{349}$ RŚl II., č. 713, 618, III., č. 310. 
ani jednu. Převládly pouze mezi potvrzovacími listinami Jana Stínavského, kde je však k dispozici jen nevelký vzorek tř́i kusů ${ }^{350}$. Mezi prřijemci se nejčastěji nachází Vratislav $^{351}$. Ovšem v rámci vysokého počtu konfirmací tu tvoří polokonfirmace jen malou část ${ }^{352}$. Tři polokonfirmace byly určeny pro Břeh ${ }^{353}$, ostatní města obdržela nanejvýše dvě en $^{35}$. Nedá se tedy říci, že by užití polokonfirmací převládalo nebo bylo preferováno některým z vydavatelů nebo př́íjemců ${ }^{355}$.

\section{Panovnický itinerář a konfirmační listiny}

V souvislosti s potvrzovacími listinami si lze rovněž položit otázku vztahu panovnického itineráře a jejich emise. Množství sledovaných vydavatelů je ve Slezsku vysoké, a proto je tu situace z tohoto pohledu více roztř́ššěná, byt' se i přesto dají vysledovat určité společné tendence. Do roku 1360 se lze pro širší srovnání opřít i o údaje o místech vydání jiných zeměpanských písemností pro tytéž příjemce (pro některá města i o údaje po tomto datu).

Pro slezské prostředí je třeba zdůraznit výraznější vliv místa pobytu zeměpána na emisi jeho písemností (nejen konfirmačních) pro města. Jinými slovy to znamená, že ve velkém množství případů byla písemnost vydána tam, odkud byl i př́ijemce. Je to ale vlastně logické. Zatímco čeští králové vládli daleko většímu teritoriu a kromě toho je panovnické povinnosti nezřídka odváděly i mimo samotné Korunní země, byla slezská knížata více vázána na svá nevelká vévodství, i když i některá z nich působila dlouhodobě mimo Slezsko. Měla úzké vztahy bud', a to nejčastěji, ke dvoru českého krále ${ }^{356}$, nebo i jiných monarchů (uherského, polského krále) ${ }^{357}$. Podle toho se také liší místa vydání zkoumaných písemností, které vydali čeští králové nebo slezská knížata. Písemnosti vydávané pro městské př́ijemce slezskými knížaty, jak patrno, prokazují následující tendenci: těch, které byly vydány mimo město, než pro které byly určeny, bylo opravdu málo. Souvisí to jednak s malou rozlohou slezských knížectví a v neposlední řadě s omezeným počtem možných knížecích rezidencí.

Pro ilustraci naznačených tezí se obrat'me ke dvěma knížatům, z jejichž činnosti se pro slezská města dochovalo nejvíce dokladů: Boleslavovi III. Marnotratnému a Bolkovi II. Svídnickému (do roku 1360). Písemnosti Boleslava III. určené pro města byly až do roku 1310 vydávány výhradně ve Vratislavi. O situaci mezi syny

350 SR č. 4138, 5142; RŚ1 II., č. 709.

351 SUb IV., č. 307; SR č. 2864; RŚl I., č. 34, 713; AP Wrocław, DM Wrocławia, č. 12586, 639 (KDPAPDS V., č. 647), 1167.

352 Proporčně zhruba tutéž jako v celkovém pohledu pro všechny zkoumané př́ijemce tedy necelou jednu třetinu.

353 SR č. 3395, 4304, 4545.

354 Dvě se dochovaly pro Lehnici a Javor.

355 S výjimkou Jana Stínavského, kde je však počet dochovaných konfirmací př́liš malý na to, aby bylo možné z tohoto stavu vyvozovat platnější závěry.

356 Viz Z. Ž a 1 u d, Dvůr Jana Lucemburského, v: Lucemburkové. Česká koruna uprostřed Evropy, Praha 2012, s. 285-290; Z Ž a 1 u d, L. B o b k o v á, Dvůr Karla IV., v: tamtéž, s. 291299; M. H o lá, Slezská knížata na lucemburském dvoře, v: tamtéž, s. 408-413.

357 S. A. S r o k a, Kariera Władysława Opolczyka na dworze węgierskim w drugiej połowie XIV wieku, v: Europa środkowa i wschodnia w polityce Piastów, Toruń 1997, s. 265-274. 
Jindřicha V. na přelomu prvního a druhého desetiletí 14. století již byla řeč. Většinovým př́jemcem Boleslavových kusů byla tehdy sice Vratislav, ale vyskytují se i jiní. Po dělení knížectví vydával písemnosti pro města v lehnickém knížectví vesměs v Lehnici - částečně s výjimkou Goldberku, kam občas zajížděl a vystavoval tam pro něj různé písemnosti. Pro města břežského knížectví hrál stejnou primární roli Břeh.

Pravidlo o závislosti knížecího itineráře a emisi písemností zcela platí i pro Boleslavovy konfirmace. Jen dvě nebyly vydány ve městě, které bylo jejím př́ijemcem. Roku 1339 to byla jedna z potvrzovacích listin pro Lehnici, kterou Boleslav vystavil ve Vratislavi ${ }^{358}$. Boleslav tehdy pobýval ve slezské metropoli v souvislosti se zástavou Lehnice a Chojnova pěti vratislavským měšt’anům ${ }^{359}$. O dva roky později vystavil v Lehnici potvrzení všech privilegií Goldberku. Šlo ale o specifickou situaci po sporu s městem a usmíření se $\mathrm{s}$ ním ${ }^{360}$.

I pro písemnosti Bolka II. platí, že bývaly vesměs vydávány v městě, které bylo zároveň jejich př́ijemcem. Přichází tu ale více výjimek, než u Boleslava III. Mezi místy vzniku Bolkových dokumentů pro města dominuje Svídnice - bývaly tu vystavovány nejen písemnosti pro ni samou, ale občas i pro jiná města. Přesto ale bylo několik svídnických kusů zlistiněno jinde ${ }^{361}$. Co se týče dokumentů pro další městské prŕijemce, nachází se mezi nimi množství těch, které vznikly přímo ve Svídnici, ale nemálo z nich tvoří i ty, kdy místo vydání i prŕíjemce byli identičtí. Knížecí rezidence v některých městech hrály někdy i významnější úlohu, nebot' v nich vznikaly i písemnosti pro jiná města: takovou roli hrál občas Landshut ${ }^{362}$ a Střehom ${ }^{363}$. Pokud jde o Bolkových pět konfirmačních listin, dvě z nich nevznikly ve městě, jež bylo jejich př́ijemcem ${ }^{364}$.

Vezmeme-li v potaz jen skupinu konfirmačních listin, pak z jejich míst vydání vyplývají následující závěry: $59 \mathrm{z}$ nich bylo vystaveno ve městě, které bylo jejich př́jemcem; v 50 př́ípadech tomu tak nebylo, ale u plných 35 konfirmačních listin neznáme (zpravidla vinou neúplného dochování) místo, kde vznikly. Avšak situace je různá u jednotlivých prŕjemců i vydavatelů. U měst, která se dostala pod prrímou vládu českého krále, stoupá počet kusů vydaných mimo město (v první řadě Vratislav). Naopak u jiných, která si udržovala pozici klíčové knížecí rezidence, se obraz neměnil: to byl případ Břehu, Svídnice (do roku 1392) a Lehnice. Konfirmace pro menší města jednotlivých knížectví vznikaly spíše v hlavní knížecí rezidenci, i když někdy zeměpán navštěvoval příslušné město a zlistiňoval tu $\mathrm{v}$ jeho prospěch.

Zeměpáni však nevydávali písemnosti jen pro města. Pro vyhodnocení jejich itinerářů by bylo nutné zohlednit také ostatní prř́jemce. Vzhledem k tomu, že bádání nad itineráři slezských knížat př́liš nepokročilo ${ }^{365}$, nezbývá než přenechat tyto otázky jiné prŕležitosti.

358 UBSL č. 114.

359 UBSL č. 117.

360 SR č. 6535.

361 SR č. 4975 (Landeshut), 6530 (Ciernie), 6708, 6709 (obě Střehom); RŚl I. č. 538 (Hiršberk), II., č. 327 (Javor), 715 (Maniów).

${ }^{362}$ SR č. $4975,5764,5882$.

363 SR č. 6708, 6709; RŚl I., č. 526.

${ }^{364}$ SR č. 5882 (pro Świebodzice v Landshutu); RŚl II., č. 11 (pro Javor ve Svídnici).

365 Přehled podává P. W ę c o w s k i, Polskie itineraria średniowieczne i nowożytne. Przegląd badań i propozycje badawcze, Studia Źródłoznawcze 37, 2001, s. 13-48 (zde s. 14-30). 


\section{Jazyk konfirmačních listin}

Již výše jsem naznačil, že konfirmační listiny byly psány latinsky déle, než ostatní listinný materiál slezských vydavatelů pro tytéž př́ijemce. Konfirmace tak tvoří svým způsobem jednu z posledních výsep, kde si latina zachovávala své výsadní postavení. Němčina se do nich prosazuje s určitým zpožděním, avšak nic to nezměnilo na jejím konečném vítězství počátkem 15 . století i v této listinné kategorii ${ }^{366}$.

O původnosti znění konfirmace Jindřicha V. pro Břeh z roku $1292^{367}$, která se dochovala $v$ němčině, byly vysloveny pochybnosti ${ }^{368}$. Šlo by o nesmírně raný př́klad užití němčiny v jedné ze slezských knížecích kancelárí. Navíc břežské knížectví bylo regionem, kde se ještě během celého 14 . století poměrně dlouho udržovala latina - platí to jak pro knížecí kancelář, tak pro městské písemnosti. S velkou pravděpodobností byla zmíněná konfirmace vydána původně latinsky.

Nejstarší nepochybně německou potvrzovací listinou byla konfirmace Jindřicha Javorského pro Lemberk z roku $1323^{369}$. Ve 20. letech vydal ještě Boleslav III. jednu z potvrzovacích listin pro Lehnici v tomto jazyce ${ }^{370}$. Ostatní jsou psány stále ještě latinsky. Více německých konfirmací je dochováno ze 40. let (pět kusů) ${ }^{371}$, ačkoliv početně za latinskými potvrzovacími listinami stále zaostávají. Úhrnem je k dispozici do roku 1350 sedm nepochybně německých konfirmací. Mezi prŕijemci se objevují města, kde je i v jiných zeměpanských písemnostech pro ně určených doložena němčina poměrně brzy. Šlo o př́ijemce ze svídnického, javorského a lehnického knížectví. Dva nejstarší příklady pocházejí, jak bylo řečeno, z Lemberku a Lehnice. Nejčastěji byl však zastoupen Goldberk ${ }^{372}$, jehož všechny tři konfirmace ze 40. let jsou německy a tímto jazykem jsou psány i všechny následující. Vedle toho přichází Landshut $^{373}$ a Javor ${ }^{374}$. Mezi vydavateli těchto nejstarších německých konfirmačních kusů (do roku 1350) figuruje pět osob: Jindřich Javorský, Bolek II. Svídnický a lehnická knížata Boleslav III., Václav I. a Ludvík I.

\footnotetext{
Z bezprostředně nás zajímající materie lze uvést jen studii $\mathrm{T}$. J u rek, In sede viduali. Nad itinerarium księżnej świdnickiej Agnieszki z lat 1385-1392, v: Europa Środkowa i Wschodnia w polityce Piastów, Toruń 1997, s. 275-289. Vedle toho je možné samozřejmě odkázat na itineráře českých králů, viz I. H l a v á č e k, K organizaci státního správního systému Václava IV. Dvě studie o jeho radě a itineráři, Praha 1991 (Acta universitatis Carolinae Pragensis, Philosophica et historica. Monographia CXXXVII); J. P a v e 1, Studie k itineráŕi Karla IV., Historická geografie 2, 1969, s. 38-78; I. H l a v á č e k, Studie k diplomatice Václava IV. Itinerár̆, Československý časopis historický 10, 1962, s. 64-94.

${ }^{366}$ Podrobněji k jazyku slezských písemností se vztahem k městům viz T. Ve li č k a, Od latiny k němčině. Slezská města jako vydavatel i př́jemce německých a latinských písemností ve 14. století, Historie - otázky - problémy 7, 2015, č. 1, s. 113-129, <http://historieotazkyproblemy.ff.cuni.cz/magazin/2015-7-1/>.

367 SUb VI., č. 83.

368 T. J u r e k, Język średniowiecznych dokumentów śląskich, Kwartalnik Historyczny 111, 2004, č. 4, s. 31.

369 SR č. 4259.

370 SR č. 4740.

371 SR č. 6635, 6694; RŚl I., č. 15, 726, II., č. 11.

372 SR č. 6535; RŚl I., č. 15, 726.

373 SR č. 6694.

${ }^{374}$ RŚl II., č. 11.
} 
Hlubšímu poznání jazykového charakteru konfirmací v následujících desetiletích, které pro ostatní zeměpanské písemnosti směřované městům představovaly období zlomu, brání značný počet kusů nedochovaných v úplném znění. Regestové zápisy z různých staletí, z nichž je tu často třeba vycházet, obvykle nezaznamenaly jazyk příslušné písemnosti. Z těch, jejichž jazykový charakter poznáváme, vyplývá, že až do 60. let (včetně) si latina udržela své vedoucí postavení před němčinou. V 70. a 80. letech bylo užití jazyků pro sledovanou konfirmační materii zhruba v rovnováze. Od 90. let již němčina převládá a z posledního sledovaného desetiletí neznáme již žádnou latinskou konfirmaci. Od počátku 90. let 14. století se tak latinské potvrzovací listiny staly výjimkami. Od tohoto okamžiku do roku 1419 se dochovaly jen dvě. Latinsky nechal svou konfirmaci koncipovat Václav IV. pro Namyslov (1397) ${ }^{375}$, latinská byla rovněž potvrzovací listina vratislavského biskupa a tehdy nově i lehnického knížete Václava II. pro Lehnici (1409) ${ }^{376}$. Naopak krátce poté jím vydaná konfirmace pro Goldberk, který, jak bylo zmíněno, měl již dlouhou tradici německy psaných konfirmačních listin, byla v němčině. Vše ostatní je na přelomu 14. a 15. století německy a souzní to tak v té době s průnikem němčiny do slezských písemností jako celku ${ }^{377}$.

\section{Konfirmační listiny podle př́ijemců}

Na závěr věnujme prostor jednotlivým příjemcům, jejich konfirmacím po stránce věcné i okolnostem jejich vydání. Ty mohly být různé, ale šlo-li o potvrzení privilegií nově nastoupivšího zeměpána, pak se zřetelně vyčleňují města, kde takový zvyk existoval. Tato města velmi rychle usilovala o konfirmaci svých práv od nového zeměpána. Jinde se naopak tento zvyk prŕiliš nevyvinul a konfirmace tu bývaly vyvolávány $\mathrm{v}$ život jinými důvody. Zdá se, že z tohoto hlediska existovala určitá regionální specifika. Pohled na archivy př́ijemců potvrzuje, že šlo o dlouhodobé tendence, na něž panující zeměpáni neměli rozhodující vliv (byt' i ten mohl být př́ležitostně uplatňován). K městům, kde taková tradice měla své místo, patřila v první řadě Vratislav. První takovou konfirmaci po nástupu nového knížete tu zaznamenáváme roku 1290, kdy Jindřich V. Tlustý potvrdil práva nejprve vratislavskému Starému a poté Novému Městu ${ }^{378}$. Rychlé změny na místním knížecím stolci v letech 1310-1311 byly doprovozeny konfirmacemi ${ }^{379}$. Totéž platí i pro nástupce vratislavských Piastovců Jana Lucemburského ${ }^{380}$, Karla IV. ${ }^{381}$

${ }^{375}$ Codex Germaniae diplomaticus, t. II., sl. 121-123, č. 13.

376 UBSL č. 438.

377 Podrobněji viz T. Veli čk a, Od latiny k němčině.

378 SUb V., č. 461, 467. C. B u śk o, M. Gol ińs ki, M. K a c z m a rek, L. Zi ą tk o w s k i, Historia Wrocławia. Od pradziejów do końca czasów habsburskich, Wrocław 2001, s. 119; M. S ło ń, Miasta podwójne i wielokrotne w średniowiecznej Europie, Wrocław 2010, s. $150-157$.

379 BU č. 88, 89, 93, 94.

${ }^{380}$ BU č. 124. Konfirmaci Jan Lucemburský vystavil v roce 1327 při př́ležitosti návštěvy města a dynastických dohod s Jindřichem VI. Vratislavským, kdy byl Jan designován jako jeho nástupce.

${ }^{381}$ BU č. 168. Karlova konfirmace vznikla roku 1341 u př́ležitosti ustanovení nástupcem jeho otce Jana. Dále BU, č. 190 (rok 1348), AP Wrocław, DM Wrocławia, č. 329 (rok 1356). 
a Václava IV. ${ }^{382}$ Počet zeměpanských konfirmací pro Vratislav se do roku 1419 zastavil na čísle 27 . V tom se jí nerovnalo žádné jiné slezské město, ale ani žádné z českých, ba ani moravských královských měst. V pozadí jejich emise stály různé důvody. Často to bývaly konflikty, které otřásaly městem, ale v nemalém počtu prŕípadů - a to je v této souvislosti podstatné - to bylo právě v důsledku výměny vládnoucího panovníka, nebo změny jeho statusu. V prrípadě Karla IV. a Václava IV. se tato změna týkala i korunovace římským císařem/králem, když oba vystavili pro město všeobecnou konfirmaci jak po svém nástupu na českým trůn, tak i po získání př́íslušné hodnosti $\mathrm{v}$ římskoněmecké říši ${ }^{383}$. V rámci vratislavského knížectví ale podobné tendence pozorujeme i u Středy, byt' až pro závěr sledovaného obdobíi ${ }^{384}$. Zvyk potvrzování privilegií novým zeměpánem dodržovala i Lehnice. Tradice zde ale vznikla o něco později než ve Vratislavi. Poprvé se zde s konfirmací po nástupu nového zeměpána setkáváme v roce 1313, kdy šlo o potvrzovací listinu Boleslava III. ${ }^{385}$ Ale pro zbytek sledovaného období již nikdy po změně na místním knížecím stolci nechybí - týká se to spoluvlády Václava I. a Ludvíka I. ${ }^{386}$, samostatné vlády Ludvíka ${ }^{387}$, Václava ${ }^{388}$, Ruprechta ${ }^{389}$, Václava II. ${ }^{390}$ a Ludvíka II. ${ }^{391}$ Totéž lze říci i pro druhé nejvýznamnější město téhož knížectví - Goldberk, kde se dochovaly konfirmace tohoto druhu od 40. let 14. stoletín ${ }^{392}$. Pro Břeh trvala tato tradice, alespoň pokud můžeme soudit $\mathrm{z}$ dochovaných písemností, jen v první polovině 14. století. V době dlouhé vlády Ludvíka I. se nezachovala žádná a totéž platí i pro jeho nástupce až do konce zkoumaného období.

Je jisté, že do dnešního obrazu listinné materie zasáhl zub času, který mohl být v př́ipadě některých měst milostivější, než jinde. Zatímco tedy pro řadu městských archivů se právě $\mathrm{z}$ tohoto důvodu musíme zdržet jakýchkoli závěrů s ohledem na existenci či absenci zvyku potvrzování privilegií novým zeměpánem, u některých měst svídnicko-javorského knížectví si to dovolit můžeme. Ta totiž v tomto směru tvořila protipól městům vratislavského a lehnického knížectví, v nichž se zvyk potvrzování privilegií novým zeměpánem př́iliš neprosadil. Archiv města Svídnice se do dnešních dnů dochoval v poměrně dobrém stavu ${ }^{393}$ a tato okolnost dovoluje

${ }^{382}$ AP Wrocław, DM Wrocławia, č. 440, 12 586. Václav vydal všeobecnou konfirmaci pro město nejprve po své korunovaci českým králem (byt' s jistým odstupem), kdy ale šlo o produkt Karlovy kanceláře, když Václav byl ještě dítětem. Po své korunovaci římským králem ji zopakoval.

383 Viz výše, pozn. 381, 382.

384 Šlo o konfirmaci Václava IV. z roku 1379, viz O. M e in a rdu s, Das Neumarkter Rechtsbuch, s. 246, č. 46.

385 UBSL č. 38.

386 SR č. 6915.

387 UBSL č. 140.

388 UBSL č. 145.

389 UBSL č. 313.

390 UBSL č. 438.

391 UBSL č. 475.

392 RŚl I., č. 15; BU č. 191; AP Wrocław, rep. 132a, dep. miasta Złotoryi, č. 5 (81), 7 (83), 53 (podle inventáre, originál nedochován).

${ }^{393}$ W. B u n k e, Das Stadtarchiv in Schweidnitz, Schlesische Geschichtsblätter 1935, s. 51-59; J. P a sław s ka, Dokumenty i akta miasta Świdnicy jako źródło do badań nad dziejami miasta i ziemi świdnickiej, Rocznik Świdnicki 1980, s. 174-181. 
relativně jistý soud. Jednotlivé konfirmace zde vznikaly z jiných důvodů, než byla výměna panujícího knížete. Všeobecné konfirmace zde nezaznamenáváme ani za vlády Piastovců, ani poté, co zde převzal vládu český král. Stejné tendence pozorujeme i u jiných měst $\mathrm{v}$ tomto knížectví - Střehomi a Lemberku. Nejspíš obdobně tomu bylo v Hlohově - výjimku tu představují jedině 30 . a 40. léta 14 . stoletetín ${ }^{394}$, kdy je vznik konfirmací spojen se změnami na místním knížecím stolci. Leč jednalo se $\mathrm{z}$ tohoto pohledu pouze o epizodu. Vůbec žádné konfirmační listiny se nezachovaly pro města nissko-otmuchovsko-grotkovského knížectví, které náleželo vratislavským biskupům. Očividně tedy v tomto regionu neexistoval zvyk potvrzování privilegií při př́ležitosti nástupu nového biskupa, ale ani jindy. Pro ostatní regiony není k dispozici dostatečná pramenná základna. Zhruba řečeno platí, že tam, kde existovala politická kontinuita, byla pocit’ována menší potřeba vzniku konfirmací tohoto druhu.

\section{ZÁVĚR A SROVNÁNÍ}

Výše uvedená zjištění ohledně potvrzovacích listin vydávaných pro slezská města se dají shrnout do několika bodů.

1) Počty konfirmačních listin pro slezské městské př́ijemce se začínají zmnožovat po roce 1300 a potom zvláště ve 40 . letech 14 . století - následující dekády představují naopak propad. Mezi vydavateli zde vystupovalo velké množství slezských knížat, ale také čeští králové a jejich hejtmani. Nejvíce konfirmací vydal Boleslav III. Marnotratný a Václav IV., např́klad Bolek II. Malý vystavoval konfirmace jen zřídka (i když vydal podobné množství všech písemností pro města jako Boleslav III.).

2) $Z$ hlediska príijemců dominovala Vratislav. Jen pro ni samotnou byla určena takřka jedna pětina všech potvrzovacích listin pro slezská města.

3) Výzkum formuláře sledovaných konfirmací byl limitován velkým počtem neplnotextově dochovaných potvrzovacích listin. Z prŕijemeckého hlediska na sobě byl často závislý text konfirmací Vratislavi a Lehnice. Obě města totiž disponovala nutnými předpoklady pro takové provázání: tradice vydávání jednoho typu konfirmací (vesměs všeobecného potvrzení), dobrý stav městského archivu a stejný jazyk konfirmačních listin.

4) Do studovaných slezských konfirmací byly inserty zařazovány poměrně málo. Jako vydavatele s vyšším množstvím insertních konfirmací lze označit jen Václava IV., Anežku Svídnickou a Jindřicha V. Tlustého.

5) Př́ijemce obvykle předkládal na počátku konfirmačního řízení listiny vydané poměrně nedávno. Aprobace výrazně starších listin jsou málo četné.

6) Konfirmace byly ve Slezsku vydávány zpravidla ve městě, které bylo i jeho př́ijemcem.

7) V potvrzovacích listinách se udržovala latina déle, než tomu bylo v ostatním listinném a mandátovém materiálu slezských vydavatelů. Od 80 . let 14 . století ale němčina převládá $\mathrm{i} v$ rámci konfirmací.

8) Z hlediska jednotlivých prŕjemců je třeba rozlišovat města podle knížectví, nebot' $\mathrm{v}$ jejich rámci se vyvinuly různé zvyky ohledně potvrzování právních aktů

394 SR 5051, 6703, 6704; RŚ1 I., č. 149, II., č. 24. 
předchůdce po nástupu nového zeměpána. V rámci vratislavského knížectví podobné tendence pozorujeme jak u Vratislavi, tak u Středy. Zvyk potvrzování privilegií novým zeměpánem dodržovala Lehnice i Goldberk. Pro Břeh trvala tato tradice, alespoň pokud můžeme soudit z dochovaných písemností, jen v první polovině 14. století. Protipól městům vratislavského a lehnického knížectví tvořila města Svídnicko-Javorska a především nissko-otmuchovsko-grotkovského knížectví, které náleželo vratislavským biskupům a kde se neujala tradice potvrzování privilegií po nástupu nového zeměpána.

Již výše v textu jsem se snažil srovnávat situaci z hlediska zkoumaných dokumentů nejen pro Slezsko. Stav zpracování této problematiky umožňuje komparaci $\mathrm{s}$ českým a moravským prostředím ${ }^{395}$.

Nejvíce konfirmačních listin se dochovalo pro slezské městské př́ijemce. O něco méně pro české adresáty a nejméně jich vzniklo pro moravské př́ijemce. Tento poměr zhruba souhlasí i s počty samotných prŕijemců (tedy zeměpanských měst), jejichž nejvyšší počet lze sledovat ve Slezsku, naopak nejnižší je na Moravě. Ani v jednom z těchto tři území se plošně neprosadil zvyk potvrzování privilegií předchůdců ze strany nově nastupujícího panovníka. Z vydavatelů $\mathrm{k}$ tomu měl nejblíže Karel IV. Jak v Čechách, tak na Moravě i ve Slezsku prokazoval nejvyšší potvrzovací aktivitu v závěru 40. a na počátku 50. let 14. století. Ve všech třech oblastech přispěl $\mathrm{k}$ zásadnímu nárůstu materie $\mathrm{v}$ tomto období. Ve Slezsku je třeba rozlišovat jednotlivé regiony, $\mathrm{v}$ rámci nichž došlo $\mathrm{k}$ různému utváření této konfirmační tradice.

Mezi př́jemci všech tř́i regionů dominovala Vratislav. Jejích 27 konfirmací bylo nedostižnou metou jak pro největší města Čech, tak Moravy. V celokorunním pohledu by se na druhém místě nacházel společně Cheb a Lehnice. Dále by následovaly Břeh se Svídnicí. Až na další prř́čce by se umístilo Staré Město pražské s deseti potvrzovacími listinami. Devět konfirmací obdržel moravský ,,premiant“ Brno, stejně jako Goldberk, který byl ale v rámci slezských měst až na pátém místě. Toto pořadí v zásadě odráží skutečnost, že vzniklo nejvíce konfirmací pro slezské příjemce. Zde se nachází hned osm měst, která přijala sedm a více potvrzovacích dokumentů. $\mathrm{V}$ Čechách to byla se stejným měřítkem jen první dvě města (třetí v pořadí měla šest kusů), na Moravě jen vedoucí Brno.

Ve všech třech oblastech se v různé míře ve sledovaných potvrzovacích listinách uplatňovaly inserty. Nikde ale ve výraznější míre nepřevládly. Pokud již převažovaly, nebyl jejich náskok vůči bezinsertním konfirmacím nijak výrazný. Více insertních než bezinsertních bylo jedině na Moravě: zhruba v poměru 1,2:1. Zde ale autorka zabývající se touto problematikou pracovala s potvrzovacími listinami pro všechny moravské př́ijemce, nejen pro královská města. V českém prostředí, přesněji řečeno v panovnických písemnostech adresovaných královským městům, naopak mírně převládaly bezinsertní konfirmace (poměr 1,15:1). Ještě méně se inserty užívaly ve slezském prostředí, kde to byla zhruba jen jedna třetina.

${ }^{395}$ Závěry týkající se konfirmačních listin z českého prostředí dle T. Ve l i č k a, Zeměpanské konfirmační listiny [disertace]; pro moravské prostředí dle L. M a r tí n k o v á, Zeměpanské konfirmační a konsensní listiny. 
Na rozdíl od předchozí kategorie potvrzovacích listin se přibližně ve stejné míře uplatnily polokonfirmace ve všech sledovaných oblastech. V Čechách a na Moravě to bylo mírně přes $20 \%$ všech potvrzovacích listin, ve Slezsku necelých $19 \%$. Zásadně se ale lišilo jejich používání v čase. Zatímco v Čechách a ve Slezsku přicházely nejčastěji v první polovině zkoumaného období a pak jejich počet pozvolna klesal, na Moravě je patrná opačná tendence.

Do určité míry se různil i formulář sledovaných písemností. Naznačil jsem, že výslednou podobu konfirmace mohl do určité míry ovlivnit její prř́jemce - a to skrze předchozí potvrzovací listiny, které byly předkládány. Potvrzují to shody jejich formuláře u některých př́ijemců. Těchto shod se ale nepodařilo najít prríliš mnoho a omezovaly se jen na vybraná města (Staré Město pražské, Vratislav, Lehnice) a tudíž i vliv prŕíjemců na textovou podobu listiny, byt' je doložen, nedosáhl výraznějších rozměrů. Výše jsem si všímal rozdílů listinného formuláře konfirmací u českých a slezských vydavatelů. V české královské kanceláři docházelo $\mathrm{k}$ větší unifikaci některých listinných částí, než tomu bylo nejen ve slezských knížecích kancelářích, ale také v moravské markraběcí. V některých případech bylo možné zjistit určitý vliv formulí české královské kanceláře na slezské knížecí kanceláře, i když tato tendence zůstává hypotézou, jež by si zasloužila samostatné pozornosti. Podrobně jsem se zabýval arengami konfirmací. Bývaly zařazovány zhruba stejně často jak do českých, moravských i slezských potvrzovacích listin. Mezi slezskými a českými konfirmacemi však existovaly určité rozdílnosti především co do volby jejich tématu (ve Slezsku byla déle užívána arenga typu memoria-oblivio), ale také zmínek o městech, které $\mathrm{v}$ arengách pro slezské městské př́jemce téměř nepřicházejí.

Konečně je třeba uvést souvislost zeměpánova itineráře a míst vydání sledovaných potvrzovacích listin. Jiná situace panovala v každém ze tří regionů. Zatímco pro české prostředí naprostá většina z nich vznikala v Praze, ve Slezsku se lišily podmínky podle jednotlivých knížectví. Čeští králové zpočátku vydávali nezanedbatelné množství konfirmací pro slezské městské př́ijemce právě ve Slezsku, ale postupně od 60. let 14. století počet takových písemností klesá. Na Moravě vedle Prahy přichází často i Brno a jiné mimočeské lokality, jakkoliv pozice Prahy tu byla stále významná.

Konfirmační listiny hrály nezanedbatelnou roli ve vládnoucí praxi sledovaných zeměpánů Slezska. Jednotliví vydavatelé i prŕíjemci se k tomuto právnímu institutu stavěli různě, což se odráží i na četnosti jejich vydávání a potažmo také dochování. Komparace těchto této oblasti spolu s Moravou a Čechami ukázala, že v nich do určité míry panovaly regionální zvyklosti, ale stejně tak docházelo ke vzájemnému ovlivňování jednotlivých vydavatelů.

\section{BIBLIOGRAFIE}

Adamska A., Arengi w dokumentach Władysława Łokietka, Kraków 1999.

Antonín R., Borovský T., Panovnické vjezdy na středověké Moravě, Brno 2009.

Bar P., Królewskie konfirmacje majątków ziemskich dla wrocławskich mieszczan z 1420 roku, Śląski Kwartalnik Historyczny Sobótka 69, 2014, č. 3.

Bogucka M., Samsonowicz H., Dzieje miast i mieszczaństwa w Polsce przedrozbiorowej, Wroclaw 1986.

Bresslau H., Handbuch der Urkundenlehre, t. II., Leipzig 1915. 
Brun P., Von Sinn und Unsinn königlicher Privilegien - Der Aargau um 1415, v: Wege zur Urkunde. Wege der Urkunde. Wege der Forschung. Beiträge zur europäischen Diplomatik des Mittelalters, Wien-Köln-Weimar 2005.

Bunke W., Das Stadtarchiv in Schweidnitz, Schlesische Geschichtsblätter 1935.

Buśko C., Goliński M., Kaczmarek M., Ziątkowski L., Historia Wrocławia. Od pradziejów do końca czasów habsburskich, Wrocław 2001.

Cafourková M., Konfirmace privilegii města Ivančic ze 17. a 18. století (Novověké revize středověkých a raně novověkých listin), Sborník archivních prací 40, 1990.

Erben W., Schmitz-Kallenberg L., Redlich O., Urkundenlehre, t. I., München-Berlin 1907.

Fichtenau H., Arenga. Spätantike und Mittelalter im Spiegel von Urkundenformeln, Graz 1957.

Fischer Ch. F. E., Geschichte und Beschreibung der schlesischen Fürstentumshauptstadt Jauer, t. I., Jauer 1803.

Gąsiorowski A., rec.: Regesty śląskie, t. I., v Studia Żródłoznawcze 22, 1977.

Hergemöller B.-U., Maiestas Carolina. Der Kodifikationsentwurf Karls IV. für das Königreich Böhmen von 1355, München 1995.

Hewig D., Kaiserliche Bestätigungen von Stadt- und Landrechten, Augsburg 1969.

Historia Śląska, t. I., díl 1., red. K. Maleczyński, Wrocław 1960.

Hlaváček I., Das Problem der Masse. Das Spätmittelalter, Archiv für Diplomatik 52, 2006.

Hlaváček I., Die Luxemburger und die böhmischen königlichen Städte des 14. Jahrhunderts im Lichte ihres Privilegiengutes, v: Die Stadt als Kommunikazionsraum. Beiträge zur Stadtgesellschaft vom Mittelalter bis ins 20. Jahrhudert. Festschrift für Karl Czok zum 75. Geburtstag, Leipzig 2011.

Hlaváček I., K organizaci státního správního systému Václava IV. Dvě studie o jeho radě a itineráři, Praha 1991 (Acta universitatis Carolinae Pragensis, Philosophica et historica. Monographia CXXXVII).

Hlaváček I., K otázce diplomatické práce v pozdním středověku, Československý časopis historický 19, 1971.

Hlaváček I., Studie k diplomatice Václava IV. Itinerář, Československý časopis historický $10,1962$.

Hlaváček I., Vratislav jako místo pobytu Karla IV. a Václava IV. (k interpretaci pozdněstředověkých panovnických itinerářů), v: Źródłoznawstwo i studia historyczne, Wrocław 1989.

Hödl G., Die Bestätigung und Erweiterung der österreichischen Freiheitsbriefe durch Kaiser Friedrich III., v: Fälschungen im Mittelalter, t. III., Hannover 1988.

Holá M., Pobyty Jana Lucemburského a jeho syna Karla ve Vratislavi 1327-1345, v: Pierwsze polsko-czeskie forum młodych mediewistów, Poznań 2007.

Holá M., Pobyty Karla IV. a jeho dvora ve Vratislavi v letech 1348-1372, v: Dvory a rezidence ve středověku, Praha 2006 (Mediaevalia Historica Bohemica, Supplementum 1).

Holá M., Slezská knížata na lucemburském dvoře, v: Lucemburkové. Česká koruna uprostřed Evropy, Praha 2012.

Holá M., Vratislavská hejtmanská kancelář za vlády Jana Lucemburského a Karla IV., Praha 2011 (Sborník archivní prací 61, suppl.).

Irgang W., Das Urkunden- und Kanzleiwesen Herzog Heinrichs III. (I.) von Glogau (+1309) bis 1300 . Zu einer Untersuchung von Rościsław Żerelik, Jahrbuch der Schlesischen Friedrich-Wilhelms-Universität zu Breslau 28, 1987.

Irgang W., Das Urkunden- und Kanzleiwesen Herzog Heinrichs IV. von Schlesien (1270-1290), Zeitschrift für Ostforschung 36, 1987.

Irgang W., Schlesien im Mittelalter. Siedlung-Kirche-Urkunden. Ausgewählte Aufsätze, Marburg 2007.

Irgang W., Verschollene Urkunden wieder in Breslau, Jahrbuch dert schlesischen Friedrich-Wilhelms-Universität zu Breslau 23, 1982.

Jurek T., In sede viduali. Nad itinerarium księżnej świdnickiej Agnieszki z lat 1385-1392, v: Europa Środkowa i Wschodnia w polityce Piastów, Torun 1997.

Jurek T., Język średniowiecznych dokumentów śląskich, Kwartalnik Historyczny 111, 2004, č. 4. 
Kahuda J., Panovnické konfirmace privilegií českých klášterů v 18. století, Paginae historiae 9, 2001.

Kobdzaj E., Archiwalia śląskie przekazane Archiwum Państowemu we Wrocławiu z Niemieckiej Republiki Demokratycznej, Archeion 84, 1988.

Kobdzaj E., rec.: Regesty śląskie, t. I., Archeion 69, 1979.

Kobzdaj E., rec.: Regesty śląskie, t. II., Archeion 80, 1986.

Koszyk S., Dokumenty pergaminowe Archiwum Miejskiego w Opolu, Ślaski Kwartalnik Historyczny Sobótka 5, 1950, s. 91-125.

Krause H., Dauer und Vergänglichkeit im mittelalterlichen Recht, Zeitschrift der Savigny-Stiftung für Rechtsgeschichte. Germanistische Abteilung 75, 1958.

Krause H., Die Rolle der Bestätigung in der Hohenstaufenzeit. Dargelegt an den frühen Barbarossa-Urkunden, v: Rechtsgeschichte und Rechtsdogmatik. Festschrift Hermann Eichler zum 70. Geburtstag, Wien 1977.

Kuhn W., Die deutschrechtlichen Städte in Schlesien und Polen in der ersten Hälfte des 13. Jahrhunderts, Marburg an der Lahn 1968.

Kuhn W., Die Städtegründungspolitk der schlesischen Piasten im 13. Jahrhundert vor allem gegenüber Kirche und Adel, Archiv für schlesische Kirchengeschichte 29, 1971; 30, 1972; 31, 1973; 32, 1974.

Kuraś S.; Przywileje prawa niemieckiego miast i wsi małopolskich XIV-XV wieku, Wrocław 1971.

Lawo M., Sprachen der Macht - Sprache als Macht. Urkundensprachen im Reich des 13. und 14. Jahrhunderts (mit editorischem Anhang), v: Die Goldene Bulle. Politik - Wahrnehmung - Rezeption, t. I., Berlin 2009.

Legnica. Monografia historyczna miasta, red. M. Haisig, Wrocław 1977.

Lindner Th., Aus dem Archive der Stadt Jauer, Zeitschrift des Vereins für Geschichte Schlesiens 9, 1868.

Lindner Th., Das Urkundenwesen Karls IV. und seiner Nachfolger (1346-1437), Stuttgart 1882.

Martínková L., Zeměpanské konfirmační a konsensní listiny z lucemburské doby pro moravské př́ijemce, Brno 2003.

Meinardus O., Das Neumarkter Rechtsbuch und andere Neumarkter Rechtsquellen, Breslau 1906.

Mohnhaupt H., Confirmatio privilegiorum, v: Privileg im europäischen Vergleich, Frankfurt a. M. 1999.

Nowakowski T., Idee areng dokumentów książąt polskich do połowy XIII wieku, Bydgoszcz 1999.

Pasławska J., Dokumenty i akta miasta Świdnicy jako źródło do badań nad dziejami miasta i ziemi świdnickiej, Rocznik Świdnicki 1980.

Patze H., Neue Typen des Geschäftsschriftgutes im 14. Jahrhundert, v: Der deutsche Territorialstaat im 14. Jahrhundert, t. I., Stuttgart 1970.

Pauser J., Privilegienkonfirmation in der Zeit Ferdinands I. Die Bestätigung der Privilegien der Städte Krems und Stein und ihr Privilegienverzeichnis von 1528, Mitteilungen des Instituts für Österreichische Geschichtsforschung 117, 2009.

Pavel J., Studie k itineráři Karla IV., Historická geografie 2, 1969.

Die Rechtsstadtgründungen im mittelalterlichen Polen, red. E. Mühle, Köln 2011 (Städteforschung A 81).

Schaube A., Urkundliche Geschichte der Gründung und ersten Entwicklung der deutschen Stadt Brieg, Brieg 1934.

Schlesisches Städtebuch, vyd. H. Stoob. P. Johanek, Stuttgart-Berlin-Köln 1995 (Deutsches Städtebuch I).

Schönwälder K. F., Geschichtliche Ortsnachrichten von Brieg, díl 1., Breslau 1846.

Schulz G., Ohlaus Vergangenheit, Ohlau 1902.

Slezsko v dějinách českého státu, t. I., red. Z. Jirásek, Praha 2012.

Słoń M., Miasta podwójne i wielokrotne w średniowiecznej Europie, Wrocław 2010. 
Spěváček J., K metodice diplomatické analýzy pozdně středověkých listin, Československý časopis historický 19, 1971.

Spěváček J., rec. na knihu: I. Hlaváček, Urkunden- und Kanzleiwesen des böhmischen und römischen Königs Wenzel (IV.), Československý časopis historický 18, 1970.

Spreitzer R., Die Belehnungs- und Bestätigungsurkunden König Sigismunds von 1421 für Herzog Albrecht V. von Österreich. Eine historische und textkritische Einordnung (12821729), Mitteilungen des Instituts für Österreichische Geschichtsforschung 114, 2006.

Sroka S. A., Kariera Władysława Opolczyka na dworze węgierskim w drugiej połowie XIV wieku, v: Europa Środkowa i Wschodnia w polityce Piastów, Torun 1997.

Šimůnek R., Lavička R., Páni z Rožmberka 1250-1520. Jižní Čechy ve středověku. Kulturněhistorický obraz šlechtického dominia ve středověkých Čechách, České Budějovice 2011.

Tadra F., Kanceláře a písaři v zemích českých za králů z rodu lucemburského Jana, Karla IV. a Václava IV., Praha 1892.

Töpfer B., Bestätigungen des Verbots von Städtebünden von 1231 zugunsten des Bischofs von Lüttich in den Jahren 1345-1348, Folia diplomatica 2, 1976.

Vašků V., Panovnické konfirmace pro moravské kláštery v 18. století. Novověké úřrední revize středověkých a raněnovověkých listin, Brno 1981.

Vašků V., Panovnické konfirmační listiny pro město Brno z let 1633-1720, Brno v minulosti a dnes 21, 2008.

Vašků V., Taxy za konfirmační listiny pro moravské kláštery v 18. století, v: Sto let od narození profesora Jindřicha Šebánka, Brno 2000.

Velička T., Die Arengen königlicher Urkunden in Böhmen 1310-1419: Das Beispiel der für Städte ausgestellten Urkunden, v: Urkundenformeln im Kontext. Formen der Schriftkultur im Ostmitteleuropa des Mittelalters (13.-14. Jahrhundert), Wien 2016 (Veröffentlichungen des Instituts für Österreichische Geschichtsforschung 65).

Velička T., Města v žateckém kraji a královští úřredníci v době předhusitské, Porta Bohemica 6, 2013.

Velička T., Od latiny k němčině. Slezská města jako vydavatel i př́jemce německých a latinských písemností ve 14. století, Historie - otázky - problémy 7, 2015, č. $1<$ http://historieotazkyproblemy.ff.cuni.cz/magazin/2015-7-1/>.

Velička T., Zeměpanské konfirmační listiny pro česká a slezská města do roku 1420 (V rámci diplomatické produkce panovnických kanceláří), Praha 2014, <https://is.cuni.cz/webapps/ zzp/detail/101630>.

Velička T., Zeměpanské konfirmační listiny pro česká a slezská města do roku 1420, Historia Slavorum occidentis 7, 2014, č. 2.

Vienken Th., Die Geltungsdauer rechtlicher Dokumente im früh- und hochmittelalterlichen Reich, Marburg 1941 (Marburger Studien zur älteren Geschichte, II 6).

Votavová R., Konfirmace městských privilegií na Moravě v 18. století, Jihomoravské okresní archivy 1983.

Votavová R., Konfirmace privilegií města Jihlavy v 18. století, Vlastivědný věstník moravský 35, 1983.

Wałkówski A., Dokumenty i kancelaria księcia legnickiego Henryka V Grubego, Wrocław 1991 (Acta Universitatis Wratislaviensis, Historia 94).

Węcowski P., Polskie itineraria średniowieczne i nowożytne. Przegląd badań i propozycje badawcze, Studia Źródłoznawcze 37, 2001

Wolfram H., Intitulatio, t. I-III., Graz-Wien, 1967-1988.

Worm P., Ein neues Bild von der Urkunde: Peter Rück und seine Schüler, Archiv für Diplomatik 52, 2006.

Zelenka J., Vznik a fungování hejtmanské správy ve svídnickém a javorském knížectví za vlády Václava IV., v: Hejtmanská správa ve vedlejších zemích Koruny české, Opava 2009.

Żerelik R., Dokumenty i kancelarie książąt głogowskich 1250-1331, Wrocław 1988. 
Żerelik R., Inwentaryzacja dokumentów w średniowiecznych archiwach śląskich, v: Inter laurum et olivam, Praha 2007 (Acta Universitatis Carolinae, Philosophica et historica 2002, 1/2. Z pomocných věd historických 16).

Žalud Z., Dvůr Jana Lucemburského, v: Lucemburkové. Česká koruna uprostřed Evropy, Praha 2012.

Žalud Z., Bobková L., Dvůr Karla IV., v: Lucemburkové. Česká koruna uprostřed Evropy, Praha 2012.

\section{Dokumenty konfirmacyjne władców dla miast śląskich do początku XV wieku}

\section{Streszczenie}

Celem artykułu jest przedstawienie przeglądu i opracowania dokumentów konfirmacyjnych (czyli dotyczących potwierdzania wcześniejszych dokumentów) wystawionych przez władców Śląska dla należących do nich miast do początku XV w. Jeżeli chodzi o procedurę konfirmacji, opierać się trzeba na bardzo ubogich przekazach źródłowych. Zgodnie z dotychczasowymi badaniami, wystawianie tego rodzaju dokumentów wiązać należy przede wszystkim ze zmianami osoby lub statusu władcy, a także ugodę z miastem, problemy z pieczęcią albo wewnętrzne potrzeby samego miasta. Konfirmację trudno pod pewnymi względami zasadniczo odróżnić od wystawiania innych przywilejów. Cechą charakterystyczną przy konfirmacji było przedkładanie do oceny potwierdzanych dokumentów. Za potwierdzenie odbiorca musiał złożyć wystawcy opłatę kancelaryjną, której wysokość jest jednak poświadczona tylko w nielicznych przypadkach. Dokument konfirmacyjny mógł przybierać różne formy: z insertem potwierdzanego dokumentu lub dokumentów, z uzupełnieniem dodatkowych postanowień (tzw. półkonfirmacja). Dokumenty potwierdzające dla miast śląskich pojawiają się po $1300 \mathrm{r}$., a ich liczba wzrasta zwłaszcza w latach czterdziestych XIV w., po czym kolejne dziesięciolecia przynoszą jej zmniejszenie. Jako ich wystawcy występują nie tylko liczni ksiażęta śląscy, ale także królowie czescy i ich starostowie. Największą liczbę tego rodzaju dokumentów wystawili książę Bolesław III legnicko-brzeski oraz król Wacław IV. Z kolei rządzący długie lata Bolko II świdnicko-jaworski wystawiał je rzadko. Wśród odbiorców dominuje miasto Wrocław. Przypada nań prawie $20 \%$ wszystkich dokumentów potwierdzających wystawionych dla miast śląskich. Wiele uwagi poświęcono w artykule formularzowi badanych pism, przy czym możliwości badawcze ograniczone są z powodu braku pełnego tekstu wielu dokumentów. Tylko w przypadku Wrocławia i Legnicy dało się stwierdzić zależności formularzowe między wystawianymi dla nich dokumentami konfirmacyjnymi. Obydwa te miasta spełniały mianowicie konieczne warunki dla takiego stewierdzenia, a więc istnienie tego samego rodzaju konfirmacji (przeważnie ogólnego potwierdzenia), dobry stan zachowania średniowiercznego archiwum miejskiego i ten sam język odpowiednich dokumentów. W badanych dokumentach rzadko zamieszczano inserty starszych dokumentów. Występują one częściej tylko w dokumentach konfirmacyjnych Wacława IV, księżnej Agnieszki świdnicko-jaworskiej oraz księcia Henryka IV wrocławskiego. Najczęściej potwierdzane były dokumenty Bolka II świdnickiego. Odbiorcy przedkładali zazwyczaj do potwierdzenia dokumenty wydane stosunkowo niedawno, nie było zwyczajem zabieganie o aprobatę wyraźnie starszych aktów. Większość dokumentów potwierdzających powstawała zazwyczaj w mieście, które było ich odbiorcą. Co się tyczy języka, to łaciny używano w dokumentach konfirmacyjnych dłużej niż w reszcie śląskiej produkcji dokumentowej, ale od lat osiemdziesiątych XIV w. także i tu zaczął dominować niemiecki. Z punktu widzenia odbiorców wyróżniać należy konkretne regiony (księstwa), w których kształtowały się odmienne zwyczaje w zakresie potwierdzania czynności prawnych władców. W księstwie wrocławskim pewna tradycja istniała już od końca XIII w. To samo dotyczy miast księstwa legnickiego. Na przeciwległym biegunie znajdowały się miasta księstwa świdnicko-jaworskiego i ziemi nysko-otmuchowsko-grodkowskiej, w których taka tradycja się nie wykształciła. 


\section{Die landesherrlichen Bestätigungsurkunden für schlesische Städte bis zum Anfang des 15. Jahrhunderts}

\section{Zusammenfassung}

In der Studie wird der Versuch unternommen, eine Übersicht über den Bearbeitungsstand der landesherrlichen Bestätigungsurkunden, die für schlesische Städte bis zum Anfang des 15 . Jahrhunderts ausgestellt wurden, vorzulegen. Was den eigentlichen Bestätigungsvorgang anbelangt, stehen uns nur spärliche Quellenzeugnisse zur Verfügung. Als Ursache für die Ausstellung entsprechender Urkunden konnten, im Einvernehmen mit den bisherigen Forschungen, vor allem Status- und Personalwechsel der regierenden Landesherren, darüber hinaus Versöhnungen mit einer Stadt, Probleme mit der Besiegelung sowie innerstädtische Bedürfnisse ausgemacht werden. Der Konfirmationsvorgang hat sich in mancher Hinsicht nicht grundsätzlich von der Ausstellung eines beliebig anderen Privilegs unterschieden. Eine Besonderheit der Bestätigungsurkunde war die vorherige Vorlage der zu bestätigenden Urkunden zwecks ihrer Überprüfung. Für die Bestätigung mußte ihr Empfänger eine Kanzleitaxe entrichten - ihre Höhe ist nur in einigen Fällen zu ermitteln. Die Bestätigungsurkunde konnte verschiedene Formen aufweisen: mit dem Insert der bestätigten (Vor)urkunde(n) oder mit ergänzenden Verfügungen. Privilegienbestätigungen für städtische Empfänger kommen in Schlesien nach 1300 auf, ihre Anzahl steigt besonders in den 40er Jahren des 14. Jahrhunderts an. In den folgenden Jahrzehnten geht ihre Zahl dann wieder zurück. Als Austeller erscheinen nicht nur viele schlesische Fürsten, sondern auch böhmische Könige und deren Hauptleute. Boleslaw II. von Liegnitz-Brieg und Wenzel IV. haben die größte Anzahl von Bestätigungsurkunden ausgestellt. Der sehr lange regierende Bolko II. von Schweidnitz-Jauer hingegen stellte nur relativ selten solche Urkunden aus.

Unter den Empfängern von Bestätigungsurkunden dominiert die Stadt Breslau, auf die allein knapp 20\% aller für schlesische Städte ausgestellten Konfirmationen entfallen. Besondere Aufmerksamkeit wurde dem Formular der Urkunden gewidmet. Der Formularuntersuchung waren jedoch durch die unvollständige Überlieferung vieler Urkunden enge Grenzen gesetzt. Nur im Fall der Urkunden für die Städte Breslau und Liegnitz konnte eine Formularabhängigkeit ihrer Bestätigungsurkunden untereinander festgestellt werden. Denn nur diese beiden Städte verfügten über die erforderlichen Voraussetzungen für diesbezügliche Rückgriffe: die Existenz eines Privilegientypus (meistens in Form der allgemeinen Privilegienbestätigung), der gute Zustand des mittelalterlichen Stadtarchivs und dieselbe Urkundensprache. In die untersuchten Urkunden wurden nur selten Inserte eingefügt - meistens kommen diese in den von Wenzel IV., Agnes von Schweidnitz-Jauer und Heinrich V. von Breslau ausgestellten Bestätigungsurkunden vor. Am häufigsten wurden die Urkunden Bolkos II. von Schweidnitz-Jauer bestätigt. Die Empfänger haben gewöhnlich zu Beginn des Konfirmationsvorganges die zeitlich jüngsten Urkunden vorgelegt. Die Approbation wesentlich älterer Dokumente war nicht üblich. Die meisten Bestätigungsurkunden wurden in der Stadt ausgestellt, für die sie bestimmt waren. In den Konfirmationsurkunden wurde die lateinische Sprache länger benutzt als in anderen schlesischen Urkundentypen. Jedoch löste seit den 1380er Jahren auch hierbei die deutsche die lateinische Sprache ab. Angesichts der unterschiedlichen Empfänger müssen konkrete Regionen (Fürstentümer) unterschieden werden, in denen sich auch, was die Bestätigung der Rechtsakte der Landesherren durch ihre Nachfolger anbelangt, verschiedene Konfirmationsgewohnheiten entwickelten. Im Breslauer Fürstentum war diese Tradition bereits am Ende des 13. Jahrhunderts vorhanden. Dasselbe gilt für die Städte des Liegnitzer Fürstentums. Einen Gegensatz bildeten die Städte der Fürstentümer Schweidnitz-Jauer sowie im Neiße-Ottmachauer und im Grottkauer Land, wo sich diese Tradition gar nicht herausgebildet hat.

Übersetzt von Waldemar Könighaus 


\section{Confirmatory documents of rulers for Silesian towns until early 15th century}

\section{Abstract}

The subject of the paper are the documents in which the ruler confirms older documents for a given town. The first part deals with confirmatory documents in general, their origins, content and typology. The second part deals with Silesian documents. The author gives a chronological survey, identifies their groups depending on the issuers and receivers, analyses formularies, discusses various types of confirmatory documents, uncovers the connections of places of issue with the itineraries of rulers, and studies the language of the documents. The problem of specific features of those documents in particular towns is also treated at length. The final part summarises the results and attempts a comparison with the situation in Bohemia and Moravia.

Translated by Rafat T. Prinke

dr Tomáš Velička, Ústav českých dějin, Univerzita Karlova, Náměstí Jana Palacha 2, CZ-116 38 Praha; Státní okresní archiv Louny, Mírové náměstí 57, CZ-440 01 Louny; e-mail: tomasvelicka@seznam.cz 